\title{
ARTICLES
}

\section{SWAPS, THE MODERN PROCESS OF FINANCIAL INNOVATION AND THE VULNERABILITY OF A REGULATORY PARADIGM}

\author{
HENRY T.C. Hu† \\ Table of Contents
}

Introduction: New Financial Products and the Modern Financial InNovation Process $\ldots \ldots \ldots \ldots \ldots \ldots \ldots \ldots \ldots . \ldots \ldots$

I. The Swap and the Swap Dealer: Basic Concepts..... 346

A. The Swap as an Exchange of Cash Flows ........... 347

1. The Interest Rate Swap................ 347

2. The Currency Swap .................. 353

B. The Swap Dealer ......................... 354

1. Role ........................... 354

2. Risks for the Swap Dealer............... 358

II. Model Twins: The Swap ANd the BIS Accord ....... 363

A. Swaps: Uses and Growth .................... 363

B. The BIS Accord and the New Generation of Financial Regulation ............................. 366

1. The Rationale for Regulation ............. 366

2. Constraints on Unilateral Intervention and the Emergence of the BIS Accord............. 370

Copyright $(\mathcal{C} 1989$ by Henry T.C. Hu. All rights reserved.

$\dagger$ Assistant Professor of Law, University of Texas School of Law. B.S. 1975, M.A. 1976, J.D. 1979, Yale University.

This paper has benefited substantially from the suggestions of Mark Gergen, Jack Getman, Robert Hamilton, Douglas Laycock, Richard Markovits, Thomas McGarity, Sally Schnitger, Jeffrey L. Seltzer, and Jay Westbrook. I also wish to thank the members of the London financial community who were kind enough to grant interviews; George Bartlett, Ross Cranston, James De Meules, Roy Goode, Chris Kandel, Perry Lerner, and Guy Wellborn for facilitating those interviews; Melissa Hamilton, Caryn Shephard, Mark Taken, and Duke Yee, for research assistance; the University of Texas Law School Foundation and University Research Institute for financial support; and W. Michael Reisman for introducing me to international decision-making while I was in law school.

Unless expressly indicated otherwise, this Article speaks as of October 1, 1989. 
3. The BIS Accord: Theory and Operation........

a. Conceptual Underpinnings of the Capital Adequacy Approach.......................... 379

b. The BIS Accord's Operative Provisions ........ 384

III. The Financial Innovation Process and the BIS ACCORD

A. Formal Rules, Constraints on Subtlety, and the Mapping

Problem

B. The BIS Accord and Obsolescence ................. 399

C. Informational Hurdles ................... 405

1. Bank Initiative and Informational Lags ....... 405

2. Diffusion and Informational Lags $\ldots \ldots \ldots \ldots \ldots 408$

IV. Dealing with Dynamism: Points of Stress and INCREMENTAL Changes

A. The Need for Incrementalism and the Scope and Type of Change ................................. 413

B. The Complexity of Evaluating an Incremental Solution.... 416

1. Specification and Swap Insurance: Surrogate Regulation as a Safety Valve ............. 418

2. Identifying Some Questions and Moving Toward Some Answers

a. Existence of Insurers ................... 422

b. Insurer Default .................. 426

c. Cost ............................ 430

V. Conclusions................................ 435

The past decade has been a golden age for innovation in corporate and international finance. Fueled by advances in computer technology and financial theory and attracted by opportunities created by extreme volatility in financial markets, financial institutions have been introducing capital market instruments and techniques at an unprecedented rate. ${ }^{1}$ Whether bearing a name which is reassuringly simple or dauntingly hermetic, whether negotiated between a financial institution and its client one-on-one or traded anonymously on

1 See, e.g., Miller, Financial Innovation: The Last Twenty Years and the Next, 21 J. Fin. \& Quantitative ANALYsis 459, 460 (1986) ("Can any twenty-year period in recorded history have witnessed even a tenth as much new development?"); Van Horne, of Financial Innovations and Excesses, $40 \mathrm{~J}$. FIN. 621, 621 (1985) ("The last six years have witnessed the greatest number of financial innovations in our nation's history ...."). Factors other than those identified in the text have also contributed to the proliferation of new financial products. See infra note 3. 
an exchange, and whether offered domestically or abroad, these new products punctuate and define the modern financial landscape.

Both a byproduct of and contributor to the integration of world capital markets, these products also can generate risks with vexatious international dimensions. Banking, commodities, and securities regulators have each viewed these risks with increasing concern. Acting within the framework of a plan to ensure the capital adequacy of international banks agreed to in July 1988 by twelve industrialized countries (the "BIS Accord"), ${ }^{2}$ banking regulators seized the initiative. These regulators have not only reined in the trillion dollar market for the "swap" - the quintessential new financial product - but they have done so in a manner which is remarkable for its level of international cooperation and analytical sophistication. The BIS Accord, when considered with the domestic regulations which implemented it in each of the respective jurisdictions, constitutes the paradigmatic international regulatory effort to deal with the new generation of financial products.

Ironically, this state-of-the-art regulatory system is largely indifferent to the underlying process of financial innovation by which new financial products continue to arise and evolve. This Article argues that such indifference undermines the integrity of this regulatory system. The 1980s have spawned a plethora of new financial products as well as a distinctive new process of financial innovation rooted in the institutionalization of change and the application of advanced financial theory. Examination of the law and economics of the swap and of the financial innovation process reveals that this process presents serious - but as yet barely recognized - challenges to the BIS Accord's regulatory system. In addition, the complexities involved in evaluating even an incremental modification to the regulatory system is revealed by way of an example. Such complexities suggest the pressing need to analyze systematically the full range of possible changes which would render the international regulatory system more accommodating of the financial innovation process.

\section{Introduction: New Financial Products and the Modern Financial Innovation Process}

The size and diversity of the market for new financial products

2 See Committee on Banking Regulations and Supervisory Practices, International Convergence of Capital Measurement and Capital Standards (1988) [hereinafter BIS ACCORD], reprinted in 51 Banking Rep. (BNA) 143 (1988). 
are mind-numbing. ${ }^{3}$ The volume figures associated with the "swap," the most important and one of the most complex of this new wave of financial products, ${ }^{4}$ are indicative. The volume of outstanding "interest rate swaps," a mechanism for dealing with interest rate vol-

3 In 1988 alone, dealers issued $\$ 172$ billion of hedging products known as "caps," "collars" and "floors." Forde, LBOs Spur Rise in Rate Protection Deals, AM. BANKER, Mar. 13, 1989, at 2; see also infra notes $187-89$ and accompanying text (describing growth of these hedging products). One of the studies which followed in the wake of the stock market crash of 1987 noted that the value of stocks represented by the volume of equity-related futures contracts traded on the Chicago Mercantile Exchange daily is about twice the value of stocks traded on the New York Stock Exchange. See Report of The Presidential Task Force on Market Mechanisms 5 (Jan. 1988) [hereinafter Presidential TASK Force].

For discussions of the factors which contributed to the flourishing of new financial products, see Study Group Established by the Central Banks of the Group of Ten Countries, Bank for International Settlements, Recent INNOVATIONS IN INTERNATIONAL BANKING 169-87 (1986) [hereinafter Cross REPORT]; Finnerty, Financial Engineering in Corporate Finance: An Overview, Fin. MGMr., Winter 1988, at 14; Germany \& Morton, Financial Innovation and Deregulation in Foreign Industrial Countries, Fed. Reserve Bull., Oct. 1985, at 743; Kane, Interaction of Financial and Regulatory Innovation, 78 AM. ECoN. Rev. 328, 330-31 (1988); Lee, What's with the Casino Society?, Forbes, Sept. 22, 1986, at 150; Morgan Guaranty Trust Company, Global Financial Change, World Fin. Markets, Dec. 1986, at 1; Ross, Institutional Markets, Financial Marketing, and Financial Innovation, 44 J. Fin. 541, 542 (1989); infra notes 8-23, 79-87 \& 191 and accompanying text.

4 See, e.g., Ardalan, Foreword to InSide the Swap Market 7 (3d ed. 1988) (describing swaps as "potentially the single most important financing development that has taken place in recent years"); Ebert, The Globalization of Financial Markets: Opportunities for Corporations and Financial Institutions, WorLd BANKING, Jan. 1987, at 23 (describing swaps as "the most visible innovation"); Forsyth, The $\$ 150$ Billion Baby: Interest Rate Swaps Are Growing by Leaps and Bounds, BarroN's, Aug. 19, 1985, at 15 (describing swaps as "arguably the capital markets' most important development of the decade"); Layard-Liesching, Swap Fever, Euromoney, Jan. 1986 (supplement), at 108 ("Swaps are at the centre of the global financial revolution."); Selling Fridges to Eskimos, Euromonex, Apr. 1989 (supplement), at 55-56 (quoting one swaps officer as saying that "[s]waps [computer] systems are the most complex systems being developed in the financial world"); Vittas, The New Market Menagerie, Banker, June 1986, at 16, 17 (describing swaps as "the most far-reaching innovation in recent years").

One enthusiastic commentator noted:

The swap market has turned the world's capital markets into a global Olympic Games. Every day, barriers are broken and records set as rival banks and corporations try new techniques to arbitrage between everchanging market conditions. Every now and then the swap market will be stunned by a fresh breakthrough, then overrun as the pack learns to imitate. Never before have transactions depended on such a fine combination of mental gymnastics, client relations and aggressive marketing. Swaps are the greatest challenge yet to the agile banking mind, and like the study of the universe itself, there is no horizon.

Shirreff, The Way to Any Market, EuromonEy, Nov. 1983, at 60. 
atility, increased two hundred fold in five years. ${ }^{5}$ Combined with "currency swaps," a corresponding mechanism for dealing with currency exchange rate volatility, the total volume of swaps outstanding as of the end of 1988 was over $\$ 1.3$ trillion. $^{6}$

The diversity of modern financial products, exemplified by unsecured debt instruments offered by corporations and by banks in recent years, is extraordinary. ${ }^{7}$ Interest may be linked in esoteric ways to various benchmark interest rates, the general price level, the prices of specified commodities, or to various stock market indices. It also may be set through auction procedures or be fixed at zero. The principal amount may be denominated in a currency different from that in which interest is paid or be denominated in a basket of currencies. The instruments may mature on the date specified, some prior date, some later date, or no date at all. The permutations seem endless.

More important than the characteristics of any particular financial product is the epochal change in the process by which new financial products are invented, commercially introduced, and then diffused in the marketplace. A change in the process of financial innovation has begun to emerge. ${ }^{8}$ At its most impressive, this process of financial innovation now has many of the features associated with the

5 See Rogers, Interest Rate and Currency Swaps, in International Securrties MARKETS 397 (1988); see also infra notes 76-78 and accompanying text.

6 See International Swap Dealers Association, Press Release (July 26, 1989) [hereinafter ISDA Press Release]. More precisely, the $\$ 1.317$ trillion swaps market consists of interest rate swaps with a total "notional amount" of \$1 trillion and currency swaps with a total "notional amount" of $\$ 317$ billion. See id. For a description of "notional amount," see infra text following note 39.

7 See Coopers \& Lybrand, A Guide to Financial InStruments 9-38 \& 65-75 (1987); Franklin Savings association, Offering Circular for Collateralized Real Yield Securities Due 2008 (Jan. 20, 1988); A. Sarwal, KPMG International Handbook of Financial Instruments and Transactions 103-33 (1989); J. Walmsley, The New Financial InStRuments: An InVestor's Guide 185-226 \& 271 316 (1988); Brenner, Fleet Sells CD With Rate Tied to Bull or Bear, Am. Banker, Sept. 8, 1987, at 1; Gerstell, Developments in Off-Exchange Financial Products, 21 REv. SEc. \& Commodrty Reg. 1, 1 (1988).

8 This Article will use the term "financial product" to refer to capital market instruments or techniques intended to provide a return as specified in the governing agreement. The term "innovation process" will be used to refer to the manner in which a financial product is developed, introduced commercially, and diffused in the marketplace. $C f$. P. Stoneman, The Economic Analysis of Technological Change 8 (1987) (describing the Schumpeterian tradition of breaking the process of technological change down to invention, innovation, and diffusion); Freeman, Innovation, in 2 The New Palgrave - A Dictionary of Economics 858 (1987) (same).

Although "financial innovation" often is used to refer to any change in the capital markets, this Article has as its focus a narrower range of phenomena. Thus, it will largely avoid discussing incremental improvements in long-standing financial 
process of technological innovation seen in recent decades in biotechnology, computer, and other science-based enterprises. The features which epitomize science-based enterprises are becoming applicable to major financial institutions.

Like technological innovation before it, financial innovation is moving from the hands of imaginative craftsmen to those comfortable with theory. ${ }^{9}$ The heavy reliance on computers, the complexity of some of the products developed, the patenting of financial products and, sometimes, the generation of financial theory long before its application, all suggest the increasingly conceptual nature of the innovation process. ${ }^{10}$ Bankers with liberal arts backgrounds who, through pluck and native ingenuity, develop useful new products through hands-on tinkering are giving way. The spotlight is moving

instruments and techniques as well as changes in the means by which funds are transferred and in the means by which corporate ownership shifts occur.

9 For discussions of the role of science in current technological innovation, see C. Freeman, The Economics of Industrial Innovation 15-18 (2d ed. 1982); Dosi, Sources, Procedures, and Microeconomic Effects of Innovation, 26 J. Econ. LrT. 1120, 1136 (1988). Cf. Kline \& Rosenberg, An Overview of Innovation, in The Positive Sum Strategy: Harnessing Technology for Economic Growth 275 (R. Landau \& N. Rosenberg eds. 1986) (discussing the overall process by which modern technological innovation occurs).

For discussions of the importance of theory in modern financial innovation, see Chew, Preface to The Revolution in Corporate Finance ix (J. Stern \& D. Chew eds. 1986); Faulhaber \& Baumol, Economists as Innovators: Practical Producls of Theoretical Research, 26 J. Econ. LIr. 577, 588-91 (1988); Lee, supra note 3, at 156; Slutsker, Physics for Investors, Forbes, June 27, 1988, at 192; Van Horne, supra note 1, at 624. This new emphasis on theory has resulted in a heavy demand on Wall Street for the services of prominent academics. See Laderman, Fischer Black is Practicing What He Teaches, Bus. WK., Aug. 6, 1984, at 75; Uchitelle, $A$ Bidding War for Professors Who Know Wall Street Ways, N.Y. Times, Aug. 1, 1989, at A1, col. 1.

10 For discussions of the utilization of computers, see French, The Comeback of the Number-Crunchers, Euromoney, Oct. 1988, at 69, 71 (noting how one kind of quantitative analysis is advancing particularly quickly because of increases in computational power); Landis, Will Supercomputers Be Super for Banks?, BANKERS Monthly, Sept. 1988, at 39, 40 (describing a German bank which uses ten supercomputers to analyze foreign exchange opportunities); Schmerken, What's Next on Wall Street's Automation Agenda: Trading Technology, Wall Street Computer Rev., Apr. 1989, at 44 (discussing commercial and investment banks engaged in developing better computer systems in connection with their capital market operations); Verity, Street Smarts: The Supercomputer Becomes a Stock Strategist, Bus. WK., June 1, 1987, at 84 ("Suddenly supercomputers are in on Wall Street.").

For an introduction to some of the intellectual property issues, see Petruzzi, Del Valle \& Judlowe, Patent and Copyright Protection for Innovations in Finance, Fin. MGmr., Winter 1988, at 66-71. Intellectual property disputes have already occurred in the financial innovations area. See, e.g., Cox, CenTrust Denies Patent Violation, Am. Banker, Apr. 26, 1989, at 2.

For an instance of how theory was ahead of application, see $A$ Bank Has to Know Its Way Around the Globe, Euromoney, Apr. 1989 (supplement), at 5. 
toward Ph.D.'s with quantitative or physical science backgrounds ${ }^{11}$ relying on the nuances of such matters as "option pricing theory"12 and hypotheses pertaining to the detection of enemy submarines and the prediction of weather. ${ }^{13}$ Whether called "quants," "lightbulb heads," "rocket scientists" or "rocketo kagakushas,"14 they compete on a global level ${ }^{15}$ to take advantage of subtle differences among and inefficiencies in today's volatile capital markets. ${ }^{16}$

11 The top quant at Salomon Brothers, Martin Leibowitz, has a master's in physics from the University of Chicago (obtained at the age of 19) and a master's and doctorate in mathematics. See Rosenberg, Salomon's Idea Machine, Institutional InvesToR, Nov. 1988, at 80,81 . Until September 1989, the head of the analytical proprietary trading unit at Morgan Stanley was a former astrophysicist (and Jesuit seminarian). See Hansell, Inside Morgan Stanley's Black Box, Institutional. Investor, May 1989, at 204, 205; Power, Hard Times in High-Tech Trading Spark Shake-up at Morgan Stanley, Wall St. J., Sept. 25, 1989, at C1, col. 4; cf. Bang That Drum, Banker, Mar. 1989, at 19 (discussing academic backgrounds of Salomon Brothers' London trading group); Pitman, Swooping on Swaps, Euromoney, Jan. 1988, at 80 ("Whether swaps teams include physicists, mathematics $\mathrm{PhDs}$, technicians or magicians, undisputed agreement is reached on the importance of state-of-the-art technical backup systems.").

12 One observer notes that "the revolution in finance is at bottom a change in the theory of valuation," and a challenge to the "accounting-oriented intuition that continues to pass for the collective wisdom of the business community." Chew, supra note 9 , at ix.

13 See Slutsker, supra note 9, at 193; Verity, supra note 10 , at 84 .

14 See Day of the Quants, Institutional Investor, Sept. 1987, at 83; French, supra note 10, at 69; Powell, Thomas \& McKillop, $A$ War of the Generations, NewsweEk, Nov. 30,1987 , at 48 .

15 The global nature of modern finance and financial innovation is described in Changes in Our Financial System: Globalization of Capital Markets and Securitization of Credit: Hearings Before the Senate Comm. on Banking, Housing, and Urban Affairs, 100th Cong., 1st Sess. (1988); Cross Report, supra note 3, at 149-68; Shearson Lehman Brothers Holdings, InC., 1987 Annual Report 10-24 (1988); M. Watson, InTERnational Capital Markets: Developments and Prospects 35-50 (1988); Slonaker \& Wiltshire, Innovative Debt Securities, 20 Rev. Secs. \& Commodrty Reg. 89, 93-94 (1987); see also infra notes 24-26, 81 \& 101.

16 Exchange rate and interest rate volatilities appear to have increased during the past decade. See Standard \& Poor's Statistical Service, Basic Statistics: BANKING AND FINANCE 15 (1985) (showing volatility of interest rates over the last twenty years); The Chase Manhattan Bank, Guide to Financial Engineering, Euromoney, Sept. 1988, at 189, 190-91. The trend is less clear as to the volatility of the U.S. stock market. See Financial Market Regulatory Reform: Hearings Before the Subcomm. on Communications and Finance of the House Comm. on Energy and Commerce, 100th Cong., 2d Sess. 131 (1988); Presidential. TAsk Force, supra note 3, at II-5.

Volatility can increase the demand for hedges and result in capital market anomalies exploitable by the nimble. See R. Brealey \& S. Myers, Principles of Corporate Finance 311 (3d ed. 1988); M. Mayer, Markets 241-42 (1988); $A$ risky business, EConomist, May 28, 1988, at 81; Day of the Quants, supra note 14, at 90; Friedland, The expert-systems revolution, INSTITUTIONAL INVESTOR, July 1988, at 77; Hansell, supra note 11, at 205; Price, The Development of the Swap Market, in SwaP 
The innovation process is also becoming institutionalized. ${ }^{17}$ With the formation of new product development teams composed of rocket scientists, traditional bankers, lawyers, operations experts, and others, as well as the appointment of officers responsible for new product development and the market testing of new financial products, a systematization of change is taking root. ${ }^{18}$

Innovation has become central to the competition among financial institutions and their lawyers. ${ }^{19}$ One institution boasts of being named the "Financial Engineer of the Year" and "showing the way toward a brave new world of corporate finance."20 Another trumpets its willingness to invent new financial tools for its customers "from scratch."21 Lawyers play a critical role in this new process:

Financing Techniques 29-30 (B. Antl ed. 1983); Why the need for financial risk management?, EuROMONEY, Apr. 1989 (supplement), at 12.

17 Cf. C. Freeman, supra note 9, at 5-15 (discussing the institutionalization of innovation in science and technology); Mansfield, The Microeconomics of Technological Change, in The Positive Sum Strategy: Harnessing Technology for Economic GROwTH 308-09 (R. Landau \& N. Rosenberg eds. 1986) (discussing the importance of scientific research and development to individual firms).

18 See Cross Report, supra note 3, at 185-86; Bates, From Evolution to Revolution, Fin. World, Sept. 16, 1986, at 119; Lee, Off with Their Legs, Euromoney, Sept. 1988, at 186; Nathans, US Innovators Still Ahead, BANKER, Mar. 1987, at 47.

In a July 1988 interview in London, a bank officer who requested anonymity noted the importance of devoting entire teams to new product development because of the range of matters involved. These matters include tax issues and questions as to where the transactions ought to be booked, how to settle, which accounts to use, how to hedge, and what capital to allocate. That same month, the author interviewed in London officers with heavy swap responsibilities at over a dozen financial institutions as well as outside attorneys and accountants actively involved in financial innovation.

19 See Bankers Trust New York Corp., 1988 Annual Report 9 (1989); R. Reidenbach \& M. Grubbs, Developing New Products: A Manager's Guide 14 (1987); Lomax, The Importance of New Financial Instruments for Activities of Banks, in NEw Financial Instruments: Disclosure and Accounting 61 (Organisation for Economic Co-operation and Development ed. 1988).

20 See Bankers Trust Company, What more can we do in '88? (advertisement), EUROMONEY, June 1988, at 10.

Commercial and investment banks are not the only entities which compete in the introduction of new financial products. See Angrist, New York Comex Picks Philadelphia's Staloff, New-Products Whiz, to be Chief, Wall St. J., July 13, 1989, at C9, col. 1 (reporting a new products specialist from one exchange moving to presidency of another); McMurray, Pit Bulls: Big Futures Exchanges in Chicago are Vying for Japanese Business, Wall St. J., Dec. 9, 1988, at 1, col. 6 (discussing competition between the two largest American futures markets in the introduction of investment products). For a model of financial innovation which focuses on the competition among exchanges, see Anderson \& Harris, A Model of Innovation with Application to New Financial Products, 38 OXFord ECON. PAPERS 203 (1986).

21 See Continental Illinois National Bank \& Trust Company (advertisement), N.Y. Times, Sept. 25, 1988, pt. 2 (Magazine), at 19; see also Chemical New York 
one of the "four ways to make partner at Sullivan \& Cromwell" is to "[i]nvent a new securities instrument."22 Relative national competitiveness in financial innovation, like competitiveness in technological innovation, has even become a source of pride or concern. ${ }^{23}$

There is a social price to be paid for all this financial innovation. Among other things, these new financial products and the underlying process through which they arise and evolve can generate enormous risks of virtually unfathomable complexity for the increasingly interdependent world capital markets. ${ }^{24}$ The brouhaha over computer-driven trading techniques which followed in the wake of the stock market crash of 1987 notwithstanding, ${ }^{25}$ the most ambitious

CorP., Form 10-K at 10 (1987) (pertaining to the fiscal year ended December 31, 1986).

22 N. Lisagó \& F. Lipsius, A LAW Unto Itself: The Untold Story of the LaW Firm of Sullivan \& Cromwell 277-78 (1988).

A lawyer involved in financial innovations must go far beyond structuring transactions in light of the applicable instrument- and institution-level regulatory environments. Lawyers also must be sensitive to less obviously relevant bodies of law which can materially affect the economics of new financial products. For illustrative examples, see, e.g., supra note 10 (intellectual property issues in financial innovation); infra note 40 (concerns over effect on swaps of prohibitions on gambling); infra note 82 (standardization of swap documentation); infra notes 87-88 (various banking, commodities, and securities law concerns); infra note 154 (ultra vires defense to enforcement of certain swaps); infra notes $163 \& 229$ (effects on swaps of bankruptcy laws); infra note 221 (tax-driven swaps); infra note 237 (litigation over departing employees); infra note 307 (litigation over regulatory approval); see also Carr \& Morton, The Deals That Kept the Lawyers Busy in 1988, INT'L Fin. L. REv., Jan. 1989, at 7-9 (discussing the success of Slaughter \& May, a leading English law firm, in creating a new financial instrument in the Euromarket); Henderson, Swap Credit Risk: A MultiPerspective Analysis, 44 Bus. LAw. 365, 377-81 (1989) (discussing bankruptcy and contract law concerns giving rise to uncertainty as to extent of credit risk); Orey, Capitalizing on Structured Finance, AM. LAw., Apr. 1987, at 12 (discussing legal involvement in mortgage-backed and asset-backed securities); Roberts, Breeding Hybrids on Wall Street, AM. LAw., Oct. 1987, at 16 (stating that colleagues described a Sullivan \& Cromwell attorney's work on currency exchange warrants as "a coup").

23 See, e.g., Nathans, supra note 18 , at 47.

24 See Cross Report, supra note 3; Fingleton, Will the System Tumble?, Euromoney, Sept. 1986, at 111; Wayne, The Realities of 'Friday the 13th'; N.Y. Times, Oct. 22, 1989, § 3, at 1, col. 2; supra note 15; infra note 101; cf. Ruder Calls for Capital Markets Unit, CoRP. Fin. WeEk, Apr. 24, 1989, at 7 (LEXIS, Nexis library, Current file) (then chairman of the Securities and Exchange Commission stating that new trading strategies involving a combination of securities, futures, currencies, and interest rate swaps contribute to increasing risks for investors and brokers).

25 There is a remarkable diversity of views on the role played by new financial products in the 1987 crash. See, e.g., Div. of Mkt. Regulation, U.S. SEc. \& Exch. Comm'n, The October 1987 Market Break (1988), reprinted in Comm. Fut. L. Rep. (CCH) No. 322 (Extra Edition) (Feb. 11, 1988); Div. of Economic Analysis \& Div. of Trading \& Mkts., U.S. Commodity Futures Trading Comm'n, (1988), reprinted in Comm. Fut. L. Rep. (CCH) No. 321 (Extra Edition) (Feb. 5, 1988); Presidential TASK ForCE, supra note 3; Bernstein \& Bernstein, Where the Postcrash Studies Went 
effort to deal with these complex risks relates not to world stock markets but instead to the international market for swaps and closely related hedging products.

Most of the risks associated with the swap market were borne by the international banks operating in New York and London serving as the linchpins of the western financial system. ${ }^{26}$ The failure of any of these banks might have immediate consequences on world liquidity and financial stability. Bank regulators believed in the need for quick action. ${ }^{27}$

The bank regulators were acting within the context of an international movement to enhance the ability of banks to deal with their "credit risks," the risks posed by bank customers defaulting on their loan, swap, and other obligations. This movement was premised on the notion that banks must have the amounts and types of capital deemed adequate in light of their respective credit risks. Ideally, this capital cushion would help banks stave off insolvency in the event of customer default. Unfortunately, unilateral action on the part of any

Wrong, Institutional Investor, Apr. 1988, at 173; Malkiel, The Brady Commission Report: A Critique, J. PorTfolio MGmT., Summer 1988, at 9; SEC Staff Study Blames Market Crash on House Tax Bill's Antitakeover Items, 21 Sec. Reg. \& L. Rep. (BNA) No. 658 (May 5, 1989).

On October 13, 1989, the Dow Jones Industrial Average fell 190 points, prompting more calls for the curbing of computerized trading techniques as well as an unprecedented degree of governmental intervention. See, e.g., Eichenwald, Outcry on Computerized Trades is Forcing Changes by Wall Street, N.Y. Times, Nov. 2, 1989, at 1, col. 3 " The outcry on Wall Street and Main Street over computerized stock trading ... has become so great that new market rules are being adopted and others appear imminent."); Uchitelle, Government Spreading Net to Break Market Free Falls, N.Y. Times, Oct. 30, 1989, at 23, col. 1 (stating that the emerging governmental intervention process includes a "handful of safety measures adopted since the 1987 crash" and quoting an economist as saying that following the 190-point plunge, "the Goverment held the market's hand and the investor's hand in a way that we have never seen before").

26 For example, approximately $70 \%$ of global swap exposure is concentrated in ten United States banks. See Ireland, Counting on your Counterparty, CoRP. Fin., Mar. 1989 , at 31. As of the end of 1988, the three largest commercial bank swap dealers accounted for more than $\$ 300$ billion of interest rate swaps. See Quint, Eliminating Risk of Rising Rates, N.Y. Times, July 31, 1989, at D1, col. 2.

The world's swap market is centered in London, New York, and Tokyo. Of these markets, the London market is the most highly developed. See Beckstrom, The Use of Computers and Technology in Swap Finance, reprinted in THE 1987 LONDON SwaPS SEMINAR 79 (1987) (transcript of address). For an up-to-date description of current market conditions, see Barclays Swaps, Barclays de Zoete Wedd, Ltd., 20 Questions and Answers - Interest Rate and Currency Swaps 25 (1988).

27 See infra note 91 and accompanying text; $f$. Council of Economic Advisers, Economic Report of the President 146-47 (1984) (describing relationship of bank failures to financial panics); Shirreff, The Fearsome Growth of Swaps, Euromoney, Oct. 1985, at 247, 247 (discussing effect of swaps on international financial stability). 
one country to impose stringent "capital adequacy" requirements on its own banks was impractical; by inflicting the costs of such requirements on its own banks, the banks of other countries would be at a competitive advantage in the global marketplace. Regulators realized that coordinated action was necessary and engaged in an intense effort to develop a framework which would promote common standards of capital adequacy. Not surprisingly, the most complex and controversial aspects of the framework involved swaps and related products.

Promulgated in July 1988 under the aegis of the Bank for International Settlements, ${ }^{28}$ the BIS Accord established minimum standards of capital adequacy for internationally active commercial banks. The central banking authorities of the Group of Ten western industrialized countries ${ }^{29}$ and Luxembourg agreed to implement these standards in their respective countries. The BIS Accord is widely considered paradigmatic in the sophistication of its regulation of complicated financial products and in its degree of international regulatory cooperation. ${ }^{30}$ In the United States, this new, enlight-

28 The Bank for International Settlements (BIS) is headquartered in Basel, Switzerland and promotes cooperation among central banks of member nations. Virtually all countries are members and the BIS manages a significant share of the world's official reserves. The BIS is commonly thought of as the "central bankers' central bank." See Bank for International Settlements: Flexible Mystique, Economist, June 17, 1989, at 94 [hereinafter Flexible Mystique]; Bederman, The Bank for International Settlements and the Debt Crisis: A New Role for the Central Bankers' Bank?, 6 INT'L TAX \& Bus. LAw. 92, 92-93 (1988).

29 The Group of Ten is composed of Belgium, Canada, France, West Germany, Italy, Japan, the Netherlands, Sweden, Switzerland, the United Kingdom, and the United States. See BIS ACCORD, supra note 2, at 1 n.1.

30 See Capital Adequacy: Playing by the Same Rules, Banking World, Jan. 1988, at 12; Cooke, The Co-ordination of Regulation, BANK ENGLAND Q. Bull., Aug. 1988, at 364; Kapstein, Resolving the Regulator's Dilemma: International Coordination of Banking Regulations, 43 INT'L ORg. 323, 323 \& 344 (1989); Moody's Investor Services, Common Bank Capital Standards: A Step Toward Global Financial Integration, Moody's Special Comment, May 9, 1988, at 1 \& 4; Spero, Guiding Global Finance, Foreign Pol'y, Winter 1988-89, at 114; Note, The Proposed Risk-Based Capital Framework: A Model of International Banking Cooperation?, 11 FoRdHAM INT'L L.J. 777, 801 (1988) (stating that the BIS proposal was an "exemplary model of international banking cooperation"); Nash, Agreement on Banks' Capital Set, N.Y. Times, July 12, 1988, at D1, col. 5; Melloan, Global Bank Regulation Fans New Debate, Wall St. J., Mar. 15, 1988, at 35, col. 3.

Securities regulators have lagged behind banking regulators in the coordination of policies on an international basis. For descriptions of current efforts to harmonize capital adequacy standards pertaining to securities firms, see, e.g., Hang loose, $M r$. Regulator, ECONOMIST, Sept. 30, 1989, at 15 (discussing efforts of world securities regulators to harmonize regulations); International Securities Regulation: Under Water Already, Economist, Sept. 23, 1989, at 96; Capital Adequacy Standards for Securities Firms: Report of the Technical Committee of the International Organization of 
ened era began on March 15, 1989, when Federal Reserve Board rules implementing the BIS Accord became effective. ${ }^{31}$

In Parts I and II this Article explains what "swaps" are and discusses those aspects of the BIS Accord and implementing regulations pertaining to swaps and related hedging products. Part III then demonstrates that the BIS Accord is subverted by the process of financial innovation in three related ways. First, the institutionalization of the innovation process causes a serious "mapping" problem with respect to the classification-based rules at the heart of the BIS Accord. The compelling need for administrative simplicity in classifications conflicts with the increasing heterogeneity of swaps and related hedging products. As a result, an increasingly diverse group of financial products will be subsumed within each classification. The consequence is that the capital adequacy requirement associated with a given classification will over time reflect increasingly badly the true risks of the products within that classification. ${ }^{32}$

Second, no formal mechanism is prescribed by the BIS Accord for changing the rules on a timely basis. The institutionalization of the innovation process and the dynamism of the financial markets will render the classifications and amounts of associated capital required under the BIS Accord increasingly obsolete. Because of the absence of such a mechanism for changing the BIS Accord stan-

Securities Commissions (Aug. 10, 1989) [hereinafter IOSC Technical Report]; infra note 149.

31 See Final Risk-Based Capital Guidelines, 54 Fed. Reg. 4,186 (1989) [hereinafter FRB Capital Guidelines] (to be codified at 12 C.F.R. pts. 208 \& 225) (Federal Reserve Board rules pertaining to state-chartered banks that are members of the Federal Reserve System, and to bank holding companies); $c$. Risk-Based Capital Guidelines, 54 Fed. Reg. 4,168 (1989) [hereinafter OCC Capital Guidelines] (to be codified at 12 G.F.R. pt. 3) (Office of the Comptroller of the Currency rules pertaining to national banks; effective December 31, 1990); Capital Maintenance: Final Statement of Policy on Risk-Based Capital, 54 Fed. Reg. 11,500 (1989) [hereinafter FDIC Capital Guidelines] (to be codified at 12 C.F.R. pt. 325) (Federal Deposit Insurance Corporation rules pertaining to Federal Deposit Insurance Corporation-insured, state-chartered banks that are not members of the Federal Reserve System; effective April 20, 1989); see also infra note 120 (supplemental capital adequacy system). The distinct regulatory aspects of bank holding companies is beyond the scope of this Article. Cf. FRB Capital Guidelines, supra, at 4194-96 (discussing applicability of BIS Accord to bank holding companies).

For information on the division of jurisdiction over banks and bank holding companies in the United States among regulators, see TASK Group on REgulation of Financial Services, Blueprint for Reform 18-19 (1984); J. Norton \& S. Whitley, Banking Law Manual $\S \S 1.03$ [2] \& 1.04[3] (1988); Scott, The Dual Banking System: A Model of Competition in Regulation, 30 Stan. L. Rev. 1, 7 (1977).

32 See infra notes 173-93 and accompanying text. 
dards, this obsolescence problem will be difficult to overcome on an internationally coordinated basis. ${ }^{33}$

Third, partly because there is no pre-clearance procedure for the introduction of new types of swaps and related products, capital requirements will, in effect, often be assigned to instruments without the benefit of information on the credit risk characteristics of those instruments. Regulators would inherently be playing a game of catch-up, always having to determine, after a bank has already introduced a new form of swap, whether the pre-existing classification structure continues to makes sense. Whatever informational problems regulators in a dynamic and secretive marketplace had to begin with are exacerbated by allowing banks to make the first move. ${ }^{34}$

Part IV of this Article begins by identifying the circumstances where the mapping, obsolescence, and informational problems are especially troublesome. Because any changes to the BIS Accord will need to be incremental in nature in the foreseeable future, one possible approach to ameliorating these problems is to supplement the capital adequacy system established by the BIS Accord with a mechanism which would operate only in those circumstances; ideally, the mechanism itself would involve incremental departures from existing practices. This Article briefly examines one way in which this might occur: a capital adequacy system supplemented by the escape valve of "surrogate regulation" 35 provided by a system of private insurers. Under this approach, the capital adequacy system would be applicable only as to those hedging products which regulators specifically designate; the regulators would in turn designate only those hedging products for which they believed the capital adequacy system works reasonably well. All other hedging products - most notably, new types of hedging products which arise subsequent to such designation - would be subject to an alternative regime. As to such nondesignated products, the swap dealer would be required to obtain insurance against losses on default of its customer from highly creditworthy financial guaranty insurers.

As this Article shows, the financial innovation process undermines the BIS Accord in a number of fundamental ways. The BIS Accord's capital adequacy approach will eventually need to be sup-

33 See infra notes $194-215$ and accompanying text.

34 See infra notes $216-258$ and accompanying text.

35 Cf. Abraham, Environmental Liability and the Limits of Insurance, 88 Colum. L. REv. 942, 954-55 (1988) (discussing how the incentives created by environmental liability insurers result in what Abraham refers to as "surrogate regulation"). 
plemented by an alternative regime in circumstances where the approach is clearly wanting or else totally replaced by a different system. This Article briefly analyzes the supplemental insurance scheme not because it favors adoption of such a scheme but as a way of illustrating some of the considerations and difficulties involved in devising a practical solution. That even a mechanism as incremental in scope and technique as this is so resistant to evaluation suggests the need for bank regulators to begin now to examine carefully the full range of possible solutions.

\section{The Swap and the Swap Dealer: Basic Concepts ${ }^{36}$}

Swaps are a potent tool for, among other things, coping with interest rate and currency rate fluctuations. By using swaps, a company can, in effect, change the interest rate and currency characteristics of its liabilities and assets at any time in ways previously inconceivable ${ }^{37}$. On the liabilities side, for instance, companies frequently issue debt on which they must pay rates of interest that float with some index of market interest rates. Despite having issued this floating rate debt, a company can fully insulate itself from the effects of rising interest rates through an "interest rate swap." Using such a swap, a company can, in effect, convert the interest on its debt from a

36 Materials submitted to the Federal Reserve Board and other federal banking agencies in connection with the development of capital adequacy rules constitute the most comprehensive publicly available analyses of the economics of swaps. This Article has relied, in part, on the data in these letters, copies of which were obtained through the Freedom of Information Act. See, e.g., infra note 57.

For more readily available introductions to interest rate and currency swaps, see Euromoney Swap Finance Service Update I (B. Antl ed. 1987); S. Henderson \& J. Price, Currency and Interest Rate Swaps (2d ed. 1988); R. Kopprasch, J. Macfarlane, D. Ross \& J. Showers, The Interest Rate Swap Market: Yield Mathematics, Terminology and Conventions 1-5 (1985); Price Waterhouse, Hedging: Foreign EXchange and Interest Rate Risk ManagementImplementation Guide 15-20 (1986); Swap Finance (B. Antl ed. 1986); J. WALMSLEY, supra note 7, at 125-47; Arak, Estrella, Goodman \& Silver, Interest Rate Swaps: An Alternative Explanation, FIN. MGMT., Summer 1988, at 12; Arnold, How to Do Interest Rate Swaps, Harv. Bus. Rev., Sept.-Oct. 1984, at 96; Bicksler \& Chen, An Economic Analysis of Interest Rate Swaps, 41 J. FIN. 645 (1986); Hammond, Recent Developments in the Swap Market, Bank of ENGLand Q. Bull., Feb. 1987, at 66; Henderson \& Klein, Glossary of Terms Used in Connection with Rate Swap, Currency Swap, Cap and Collar Agreements, Butterworth's J. Int'z Banking \& Fin. L., June 1987 (Supp.); Smith, Smithson \& Wakeman, The Market for Interest Rate Swaps, Fin. MGMT., Winter 1988, at 34.

37 See Ardalan, supra note 4, at 7. Companies can not only use swaps in connection with their liabilities (as discussed in the text) but also in connection with their assets. For discussion of how this might be done, see the references in infra notes 44 and 85 . 
floating rate to a fixed rate. Interest rate swaps also can allow companies to convert fixed rate debt to floating rate debt or convert an interest rate floating with one index of market interest rates to a rate floating with another index of market interest rates. By using currency swaps, a company can move beyond mere interest rate concerns and alter the currency characteristics of its assets and liabilities in order to protect itself from the fluctuations in currency exchange rates.

As might be expected, a company in the market for such complex financial instruments generally looks to swap dealers, usually large financial institutions or their affiliates. These financial institutions assume certain risks. In the simplest case, ${ }^{38}$ the primary risk is the "credit risk," the risk that the bank's customer will default on its obligations under the swap. This is the risk with which the BIS Accord is primarily concerned.

\section{A. The Swap as an Exchange of Cash Flows}

\section{The Interest Rate Swap}

In its most basic form, an interest rate swap involves: (1) one party (typically called the "fixed rate payor") agreeing to make periodic payments to the other party which are fixed in amount in return for (b) the other party (typically called the "floating rate payor" or the "variable rate payor") agreeing to make periodic payments to the first party that vary with the "prime rate," "LIBOR," or some other benchmark of market interest rates. ${ }^{39}$ The payments exchanged by the parties are analogous to interest payments on a purely hypothetical principal amount (typically called "notional principal amount" or "notional amount"). No payments analogous to principal payments are made.

This "plain vanilla" interest rate swap can be analogized to a bet. ${ }^{40}$ A party concerned primarily with interest rates rising should

38 This is the case in which a bank has interposed itself between perfectly matched parties, illustrated in Figure 4 and discussed infra text preceding note 57.

39 Broadly speaking, the "prime rate" is the rate of interest charged by a bank for loans made to its most creditworthy customers and "LIBOR" or London Interbank Offered Rate is the rate that major international banks charge each other for large loans of dollars outside the United States. See INTERNATIONAL Swap Dealers association, Inc., 1987 Interest Rate and Currency Exchange Definitions 22-23 (1987) (offering various technical definitions of the prime rate and LIBOR).

40 The term "plain vanilla," when used broadly, refers to any simple or common swap; when used more narrowly, the term refers to particular examples of such kinds of swaps. See Cross Report, supra note 3, at 265; A. SARwal, supra note 7, at 313; 
assume the role of the fixed rate payor. A party concerned primarily with interest rates falling should assume the role of the floating rate payor. Interest rates will either rise or fall subsequent to commencement of the swap:

(1) If interest rates were to rise, the floating rate payor's payments to the fixed rate payor (the "floating rate payments") would be larger than the fixed rate payor's payments to the floating rate payor (the "fixed rate payments"). ${ }^{41}$ On a net basis, the fixed rate payor would receive money on the swap. ${ }^{42}$ Thus, the fixed rate payor would be "in the money" on this swap, helping the fixed rate payor weather an environment of higher interest rates.

(2) If interest rates were to fall, the fixed rate payor's payments to the floating rate payor would be larger than the floating rate payor's payments to the fixed rate payor. On a net basis, the floating rate payer would receive money on the swap. The floating rate payor would now be "in the money" on this swap, helping protect the floating rate payor from a lower interest rate environment.

What might this bet between these "counterparties" look like in the real world? Assume that a savings and loan association has obtained its deposits by way of money market accounts paying depositors rates of interest that vary with market interest rates, and has in turn loaned the entire amount to home buyers in the form of fixed rate mortgages. If interest rates rise, the savings and loan will

Olander \& Spell, Interest Rate Swaps: Status under Federal Tax and Securities Laws, 45 Mp. L. REv. 21, 23 n.7 (1986).

The gambling flavor of swaps has caused some discomfort over the possibility that swaps violate gaming laws. See 2 G. Penn, A. Shea \& A. Arora, The Law and Practice of International Banking 247-50 (1987); Puleo, Recent Developments in Merchant Banking Activities of Banks and Bank Holding Companies, in 2 BankING LAW AND Regulation 1988 at 14 (F. Puelo \& B. Smith eds. 1988); cf. Fin. Mgmt., Spring 1987, at 21 (advertising the Third Annual Symposium on Cash, Treasury and Working Capital Management, held in Las Vegas).

41 This assumes a "par" interest rate swap, a swap in which the fixed interest rate on the swap is equal to the then current market swap rate. See Ferron \& Handjinicolaou, Understanding Swap Credit Risk: The Simulation Approach, J. INT'L. SEc. MARKETS, Winter 1987, at 135, 142.

42 For purposes of simplicity, the text assumes that the floating rate payor makes the floating rate payments to the fixed rate payor and the fixed rate payor makes the fixed rate payments to the floating rate payor. In practice, these payments are typically "netted" so that the party owing the greater amount simply pays the excess to the other party. See International Swap Dealers Association, Interest Rate and Currency Exchange Agreement § 2(c) (1987) (setting forth a typical "netting" clause). For discussions of swap documentation, see Henderson, supra note 22, at 385-87; infra note 82 . 
not be long for this world. This is so because an increase in interest rates will raise its cost of obtaining money while its income from the mortgages would remain fixed. ${ }^{43}$

Luckily for the savings and loan, there happens to be a consumer finance company that has an asset-liability mismatch which is reverse to that of the savings and loan. The finance company has obtained its funds by issuing bonds bearing a fixed rate and has lent to its customers on a floating rate basis. This finance company might want to avoid this asset-liability mismatch because of its concern over the possibility that interest rates might drop.

The needs of the finance company and the savings and loan are complementary. Figure 1 shows how an interest rate swap in which the savings and loan is the fixed rate payor and the finance company is the floating rate payor would benefit both parties. Pursuant to the swap (represented in the diagram by arrows linking the two entities), the savings and loan makes fixed rate payments to the finance company in return for floating rate payments.

If interest rates were to rise, the savings and loan would have to pay more to its depositors. However, a corresponding increase in the size of the floating rate payments that the savings and loan would receive pursuant to the swap could be used to pay the higher interest rates to depositors. Similarly if interest rates were to drop, the finance company would receive less from its customers. However, the finance company could continue to meet its obligations on its fixed-rate debt by using the fixed amounts it would receive pursuant to the swap to pay its bondholders. The ability to apply payments the parties receive under the swap to their respective liabilities has, in effect, insulated both parties from interest rate risk.

43 For discussions of asset-liability management policies and techniques, see $R$. Harrington, Asset and Liability Management by Banks (1987); R. Platt, Controlling Interest Rate Risk: New Techniques and Applications for Money MANAGEMENT (1986). 
(ASSETS)

(ASSETS)

savings and loan association customers who have fixed rate mortgages

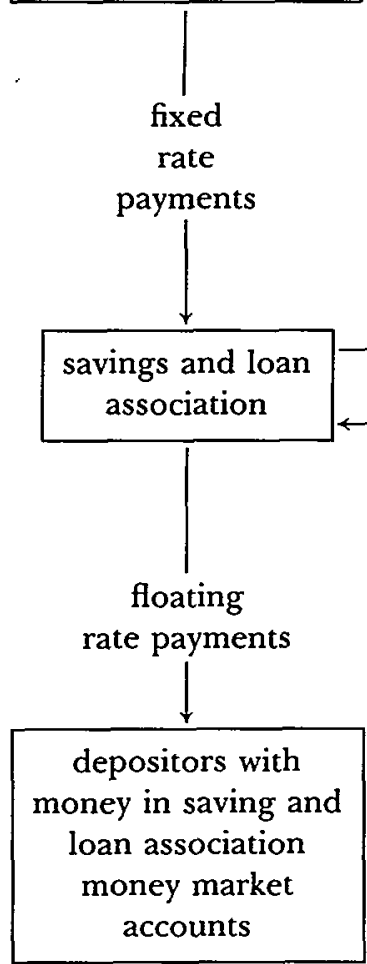

(LIABILITIES)

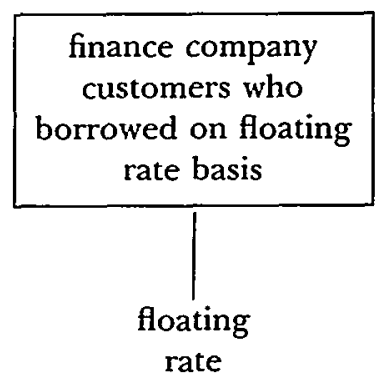

payments

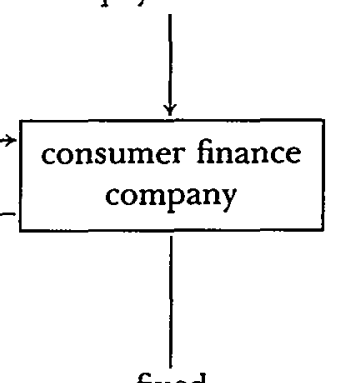

fixed

rate payments

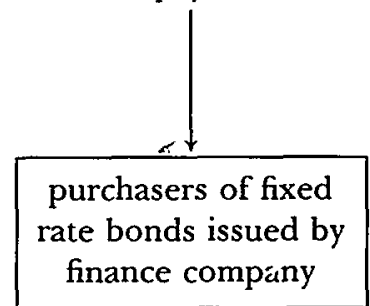

(LIABILITIES)

Figure 1.

While this example shows how interest rate swaps are useful as hedges against interest rate fluctuations, interest rate swaps can be used in other ways as well. For instance, swaps can allow corporations to "arbitrage" subtle economic, tax or regulatory differences in capital markets. ${ }^{44}$

44 Although this Article illustrates only the arbitrage use of swaps in connection with company liabilities, swaps are sometimes used as well in connection with company assets in order to create "synthetic securities." See A. SARwaL, supra note 7, at 324-29; Henderson, Economics of Swaps, in INTEREst RATE AND CuRRENCY Swaps 1987 at 18-23; Swapping Mad, Economist, Nov. 4, 1989, at 99; infra notes 53-55, 83 \& 
The classic example for illustrating this arbitrage use to swaps focuses on differences between the capital market for fixed rate borrowings and the capital market for floating rate borrowings. ${ }^{45}$ At bottom, the example involves an extension of the classical theory of comparative advantage from trade in goods to "trade" in money.

In the goods context, each party should produce goods in which it has a comparative advantage and then exchange those goods in the international market in order to reach its desired mix of goods. By obtaining the desired mix of goods through trade rather than producing the desired goods itself, each party reaches a higher level of welfare. ${ }^{46}$

Thus, assume that a borrower would prefer borrowing on a fixed interest rate basis to borrowing on a floating rate of interest basis. However, this borrower appears to have relatively better access to the capital market for floating interest rate borrowings than it has to the capital market for fixed interest rate borrowings. Since the borrower has a comparative advantage in floating rate money, it should borrow on a floating rate basis and then somehow "trade" the floating rate money for fixed rate money. The swap allows this kind of "trade" to occur: if the trade works as intended, the borrower can obtain fixed rate money more cheaply through the use of the swap than if it tried obtaining such money directly.

In Figure 2, a savings and loan has $\$ 100$ million dollars in deposits on which it pays a floating rate of interest equal to the sum of a specified prime rate ("Prime") and $3 / 4 \%$. The savings and loan is a typical savings and loan, living from day to day at the very edge. Since the capital market for fixed rate borrowings tends to be quite sensitive to credit quality, ${ }^{47}$ the savings and loan would have to pay a high rate of interest for fixed rate borrowing (say, $13 \%$ a year). On the other hand a finance company, because it is somewhat more

85, cf. infra notes 53-55, 83 and accompnaying text (discussing arbitrage opportunities).

45 Although most participants in the swap market subscribe to the kind of arbitrage analysis illustrated in the text, this analysis is not completely satisfying. For critiques of the standard swap arbitrage analysis, see Arak, Estrella, Goodman \& Silver, supra note 36, at 12; Smith, Smithson, \& Wakeman, supra note 36, at 41-42; Turnbull, Swaps: A Zero Sum Game?, Fin. MGmT., Spring 1987, at 15.

46 See, e.g., H. Grubel, InTERnational. Economics 11-23 (1981) (explaining world gains from trade and specialization).

47 See C. Beidleman, Financial Swaps: New Strategies in Currency and Coupon Risk Management 214-18 (1985); Tomlinson, Principles and Applications of Interest Rate Swaps, in THE 1987 London SwaPS SEMINAR, supra note 26, at 165 (transcript of address). But see Smith, Smithson \& Wakeman, supra note 36, at 41-42; Turnbull, supra note 45 , at 20. 
creditworthy than the savings and loan, can issue bonds in the principal amount of $\$ 100,000,000$ bearing interest of $11 \%$, a rate fully two percentage points lower than the savings and loan's cost of fixed rate borrowing. Of course, the finance company could have borrowed on a floating rate basis, as did the savings and loan. However, as an empirical matter, the finance company will only be able to do slightly better than the savings and loan when borrowing on a floating rate basis. The finance company can borrow at the sum of Prime plus $\mathrm{l} /$ $8 \%$, only $5 / 8$ of a percentage point lower than the rate obtained by the savings and loan. The possible alternatives for borrowing are shown in Table 1.

$\begin{array}{lcc}\text { savings and loan } & \text { floating rate } & \frac{\text { fixed rate }}{13 \%} \\ \text { finance company } & \text { Prime }+3 / 4 \% & 11 \% \\ \text { differential: } & \text { Prime }+1 / 8 \% & 2 \%\end{array}$

Table 1

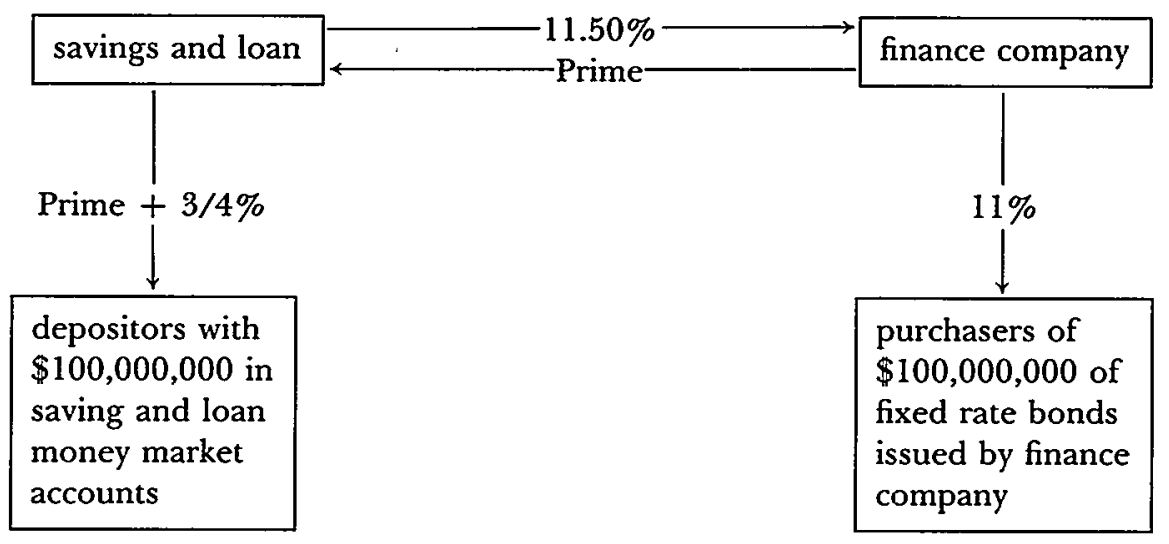

Figure 2.

Because the finance company is more creditworthy, it has an absolute advantage in borrowing money on either interest rate basis. However, the savings and loan has a comparative advantage in borrowing at a floating rate. As a result, the savings and loan should borrow at a floating rate, the finance company should borrow at a fixed rate, and the two entities should then "trade" through use of a swap. Such a swap might call for the savings and loan to make payments of $\$ 11.5$ million each year to the finance company in return 
for the finance company making annual payments equal to Prime on the hypothetical principal amount of $\$ 100,000,000$. The savings and loan would be effectively paying $11.5 \%$ "interest" on a "notional principal amount" or "notional amount" of $\$ 100,000,000$ and receiving "interest" equal to Prime applied to the same notional amount of $\$ 100,000,000$.

By entering into the swap, the savings and loan can effectively reduce its fixed rate of interest from $13 \%$ per year to $12.25 \%$ [e.g., (Prime $+3 / 4 \%)+(11.50 \%)-$ (Prime) $]$. At the same time the finance company can effectively reduce its floating rate of interest from Prime $+1 / 8 \%$ to Prime $-1 / 2 \%$ [e.g., (11\%) + (Prime) $11.50 \%]$.

\section{The Currency Swap}

With interest rate swaps, the parties never make any payments of principal. The only payments made can be characterized as de facto interest payments on a purely hypothetical principal amount. With the currency swap, however, there are exchanges of both interest and principal. By carefully structuring these exchanges, parties can hedge against both currency and interest rate fluctuations. The currency swap also may offer arbitrage possibilities. ${ }^{48}$ If a company has a comparative advantage in the fixed interest rate Deutsche mark capital market but prefers floating rate United States dollars, it could reduce its borrowing costs through a currency swap. The company can borrow in the fixed rate Deutsche mark capital market and then, through a currency swap, transform the fixed rate Deutsche marks to floating rate United States dollars. Obtaining such funds indirectly can be cheaper than doing so directly. A simple illustration is set forth in the footnote. ${ }^{49}$

48 See Ardalan, supra note 4, at 9; Hammond, supra note 36, at 71. But see supra note 45 .

49 Assume that an American company wants $\$ 50$ million at a floating rate of interest, say a specified prime rate ("Prime"). Unfortunately, this American company has relatively poor access to floating rate United States dollars; it would have to pay Prime $+1 / 8 \%$ for the money.

Assume further that, for historical and other reasons, this American company has relatively better access to the German capital market than the American capital market. The American company can borrow in the German capital market because of its comparative advantage in that market, and then "trade." Assume that there is a German company which wants DM100,000,000 at $4 \%$ fixed interest rate. Unfortunately, though, this German company happens to have relatively poor access to fixed rate Deutsche marks; it would have to pay $41 / 8 \%$ for the money. The 


\section{B. The Swap Dealer}

\section{Role}

The example about the savings and loan and the consumer finance company assumed that two parties with precisely complementary needs existed, that they would meet, that they would enter into a swap, and that they would live happily ever after. In the real world, needs may not be precisely complementary. One party's desires concerning the notional amount, the swap payments, and the

German company believes that it has relatively better access to the American capital market than the German capital market.

The two companies were meant for each other, as described below and shown in Figure 3. The German company can obtain floating rate United States dollars and the American company can obtain fixed rate Deutsche marks and then the two companies can "trade." Assuming that at the inception of the swap the exchange rate was two Deutsche marks to one United States dollar, the companies can trade in the following manner:

(a) At the inception of the swap (concurrent with the United States company's issuance of DM100,000,000 of bonds bearing interest at $4 \%$ in the German market and the German company's issuance of $\$ 50,000,000$ at Prime in the United States market), the United States company gives the DMI00,000,000 in offering proceeds to the German company in return for $\$ 50,000,000$ in offering proceeds from the German company. At time zero, the U.S. company thus has $\$ 50,000,000$ in its coffers and the German company has DM100,000,000 in its coffers.

(b) During the term of the swap (coinciding precisely with the terms of the two bond issues), the United States company pays an amount equal to interest at Prime on $\$ 50,000,000$ to the German company in exchange for DM4,000,000 (e.g., four percent of DM100,000,000) each year from the German company. Each company takes the swap payment it receives and gives to its bondholders. In effect, during the term of the swap, the United States company is paying "interest" equal to Prime (in United States dollars) and the German company is paying "interest" equal to $4 \%$ (in Deutsche marks).

(c) On the termination date of the swap (coinciding with the maturity dates of the bonds), the U.S. company pays the German company $\$ 50,000,000$ and receives DM100,000,000 from the German company. The German company takes the $\$ 50,000,000$ it receives in order to pay off its bondholders and the American company takes the DM100,000,000 it receives in order to pay off its bondholders.

As a result of this swap, the United States company effectively received $\$ 50,000,000$ from issuance of the bonds in Germany, paid interest at Prime during the term of the bond, and at maturity paid $\$ 50,000,000$. The German company effectively received DM100,000,000 from the issuance of the bonds in the United States, paid interest at four percent during the term of the bonds, and at maturity, paid DM100,000,000. This process occurs regardless of changes in the United States dollar/Deutsche mark currency exchange rate. The United States company has achieved its goal. 
beginning and end dates may be different from the desires of the other party. Even if two perfectly suited parties exist, there is no reason to suspect that they will find each other. Even if they find each other, there is no reason why these two parties may actually be willing to deal with each other. Furthermore, if they were to enter into a swap, there is a possibility that the party "losing" the bet would seek to repudiate the agreement.

Additionally, with respect to the putative arbitrage possibilities inherent in a swap, parties must be able to monitor world capital markets continuously, recognize subtle differences in those markets, determine how to take advantage of those differences, and actually take advantage of those differences. In the real world, few institutions, financial or otherwise, would find it worthwhile to engage in such an undertaking. ${ }^{50}$

In essence, the simple examples above assume away the need for a swap dealer, a combination of matchmaker, guarantor and wise man. ${ }^{51}$ Typically a major commercial or investment bank or an affiliate, the swap dealer is a party to the vast majority of swap agreements. ${ }^{52}$

The role of wise man is the swap dealer's most difficult. The

at inception

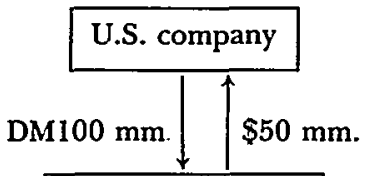

German company

(initial exchange of principal) during the term

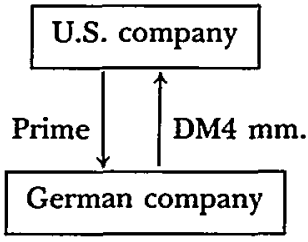

(periodic exchange of interest) at termination

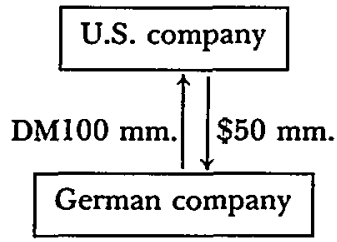

(final exchange of principal)

Figure 3

50 See Beckstrom, supra note 26, at 79; Stillit, Money for nothing arbitrage by Daiwa, CoRp. Fin., May 1987, at 24-25; Monroe, Firms Return in Force to Credit Markets With Debt Linked to Interest Rate Swaps, Wall St. J., Nov. 20, 1987, at 40, col. 3. But of. Keller, The Rocket Men are Still at Work, EuROMONEy, Sept. 1989, at 148 (concerning increasing sophistication of corporate customers as to swaps and related products).

51 These functions are separable. Some financial institutions participating in the swaps market, for instance, do not serve in a guarantor capacity. See BANK OF England, The Regulation of the Wholesale Markets in Sterling, Foreign Exchange and Bullion 38-39 (1988) [hereinafter Wholesale Markets]; Crabbe, Clearing House for Swaps, Euromoney, Sept. 1986, at 345, 347; Kolman, The Sultans of Swap, InSTITUTIONAl INVESTOR, Oct. 1985, at 258, 264.

52 One leading swaps dealer is affiliated with an insurer. See AIG Financial Hires 
constant monitoring of subtle differences in capital markets leads to strategies which can arguably offer opportunities to borrow at lower cost or obtain higher risk-adjusted returns. ${ }^{53}$ The opportunities can be highly transitory. Pepsico reportedly took advantage of one opportunity which existed for only three hours. ${ }^{54}$ Opportunities can also be difficult to detect and exploit. One $\$ 100$ million aircraft financing involved the use of 240 swaps. ${ }^{55}$

As a matchmaker, a bank may be able to find a party with needs complementary to its client's, a capacity derived from its world-wide information network. However, such knowledge may not be enough because the party with complementary needs might be unfamiliar to the client and might be of dubious credit standing. Consequently, the bank will typically have to serve as a guarantor, interposing itself between the two parties in such a way that it substitutes its credit standing for those of the parties.

An example will help illustrate the matchmaker and guarantor functions. In its matchmaker role, the bank may have determined that the savings and loan and the finance company in our example were perfect for each other. But the finance company's concern with the creditworthiness of the savings and loan may preclude it from entering into a swap directly with the savings and loan. The bank could break this impasse by simultaneously entering into two separate swaps, one with the finance company and one with the savings and loan. In its swap with the finance company the bank would make fixed rate payments and receive floating rate payments. In the "matching" or "mirror" swap with the savings and loan, the bank would receive fixed rate payments and make floating rate payments.

Eight; Plans to Expand Swap Effort this Year, SEC. WEEK, Mar. 7, 1988, at 9; AIGlobal to Service Multinational Firms, Bus. INs., Apr. 17, 1989, at 64.

Corporations appear to be increasingly able to bypass banks in even complicated financial transactions. See Roden, Forex Funding Free of Banks, Euromoney, May 1989, at 102-103.

53 See Lee, supra note 18; Wilson, Designing a Swap Package, in INSIDE THE SwaP MARKET 33-36 (3d ed. 1988); supra note 44; infra note 85 and accompanying text.

54 Fleet-footed Pepsico Exploits T-Bill Swap Window, Corp. Financing Week, May 8, 1989 , at 4 .

55 See A Deal with 240 Swaps, Euromoney, July 1, 1988, at 80; $f$. Kolman, supra note 51 , at 259 ("A single swap can blossom into a 'daisy chain' of as many as a halfdozen interrelated components that change constantly with the smallest interest rate fluctuations."); Wall St. J., Nov. 20, 1987, at 40, col. 3 ("The more legs you have on [a] transaction ... the more chances you have of some sort of [market] imperfection along the line."). 
The "mirror swaps" into which the bank would enter are described in the footnote ${ }^{56}$ and illustrated in Figure 4.

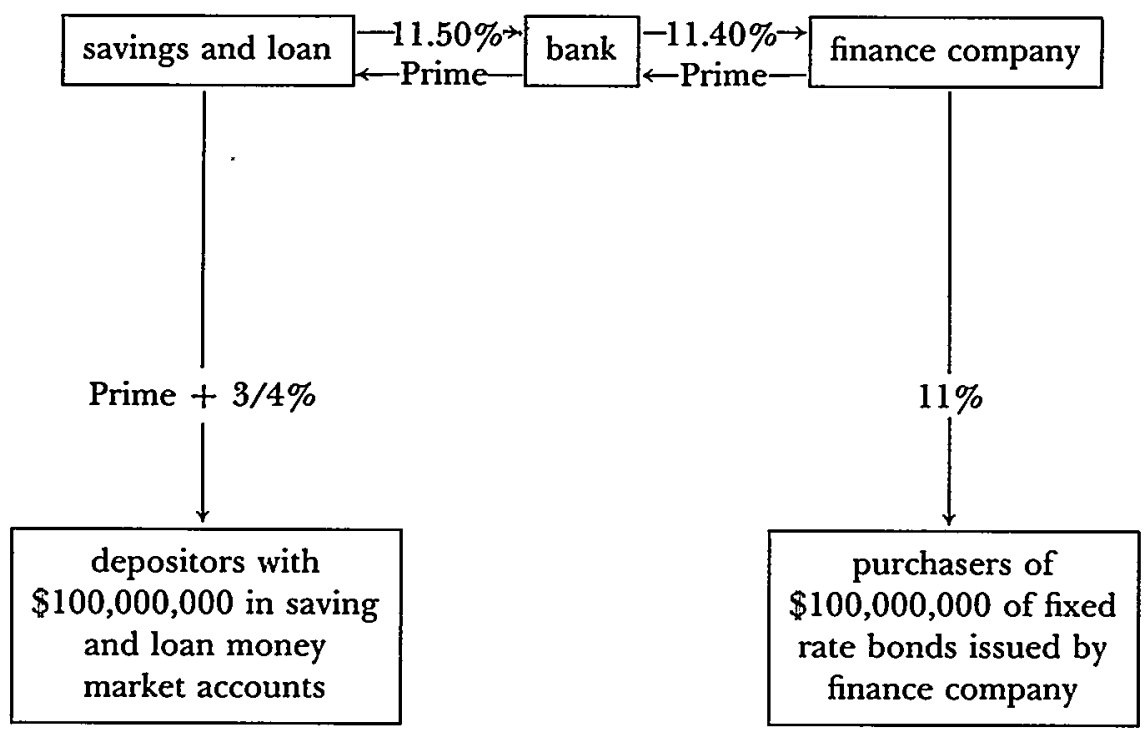

Figure 4.

With such perfectly matched mirror swaps, the bank is perfectly hedged, and need not worry about interest rates going up or down. If interest rates were to rise, the bank would pay more to the savings and loan than it received; at the same time, it would receive more than it paid on the "mirror swap" with the finance company. Similarly, if interest rates were to drop, the bank would pay more to the finance company than it received; at the same time, it would receive more than it paid on the "mirror swap" with the savings and loan. As long as neither the savings and loan nor the finance company defaults on its swap obligations, the bank will make money each time swap payments are made. In the example in Figure 4, the dealer has a profit margin of about $.10 \%$ a year.

56 Under the bank's agreement with the finance company, the bank would pay $\$ 11.4$ million a year to the finance company and the finance company would pay to the bank each year an amount equal to Prime applied to $\$ 100$ million. Under its separate and independent agreement with the savings and loan, the bank would receive $\$ 11.5$ million each year and would pay an amount equal to Prime applied to $\$ 100$ million. The bank, in effect, passes along the payment it receives from the savings and loan to the finance company (less the bank's $\$ 100,000$ slice), and passes along the payment it receives from the finance company to the savings and loan. 


\section{Risks for the Swap Dealer ${ }^{57}$}

In the real world, the swap dealer's life is not quite that easy. For instance, in the previous example, the bank was lucky enough to have found a party (the consumer finance company) whose needs were complementary to the savings and loan's in every respect. In the real world, the bank might not find such a perfect match. ${ }^{58}$ Indeed, instead of undertaking the matchmaking process, the bank may attempt to hedge its swap with the savings and loan "synthetically"59 with mathematical strategies involving publicly traded financial instruments. ${ }^{60}$ In the world of finance a perfect hedge is elusive: "[t]he only perfect hedge is in a Japanese garden."61

Apart from the interest rate or exchange rate risks, the swap dealer faces the risk that its customer will fail to perform according to the terms of the swap. The swap dealer is thus exposed to "credit

57 The risk analysis has been simplified considerably. In the analysis of credit risk, for instance, this Article will not refer to the replacement costs of "matched pairs" of swaps or the bankruptcy and contract law complications which can affect the quantification of credit risk. See supra note 40 (effect of prohibitions on gambling); infra note 63 (portfolio issues); infra note 154 (ultra vires defense to enforcement of certain swaps); infra note 163 \& 229 (effects on swaps of bankruptcy laws); infra note 221 (tax-driven swaps). The most detailed publicly available analyses as to the credit, interest rate, exchange rate, and other risks assumed by swaps dealers are found in the comment letters referred to in supra note 36 . More readily available materials include Ardalan \& Seigel, Swap Exposure and Regulatory Concerns, Euromoney Corp. Fin., Nov. 1985, at 82; Balman, Risk Assessment and Control, in The 1986 Annual London Swaps Seminar 70 (1986); Ferron \& Handjinicolaou, supra note 41; d'Souza, Managing Risks in Swaps, in The 1987 London Swaps SEMINAR, supra note 26, at 121; Potential Credit Exposure on Interest Rate and Foreign Exchange Related Instruments [hereinafter $F R B / B O E$ Credit Exposure Memorandum], reprinted in INTEREST RATE AND Currency Swaps 1987, at 325; Whittaker, Interest Rate Swaps: Risk and Regulation, Econ. REv., Mar. 1987, at 8-10 (published by the Federal Reserve Bank of Kansas City).

58 The bank may find, for example, that the savings and loan wants a notional amount of $\$ 100$ million while the finance company desires a notional amount of only $\$ 20$ million. The bank may need to find parties in addition to the finance company who are willing to make floating rate payments on a swap. Moreover, the savings and loan may want a swap period which differs from the swap period desired by the other parties. To the extent that the swaps entered into by the bank are not perfectly complementary, the bank is taking some interest rate or currency risks in addition to the credit risk.

59 See International Swaps: Has the Swap Market Moved Full Circle?, INT'L Fin. REv., Apr. 27, 1985, at 927; Lawton \& Metcalfe, Portfolio Approach to Swapping Swaps, in Euromoney Swap Finance Service - Update I, at 13 (B. Antl ed. 1987).

60 See Gelber, Elementary Hedging Techniques for Swaps, in THE 1986 ANnual LONDON SWAPS SEMINAR, supra note 57, at 107 (transcript of address); Smith, Smithson \& Wakeman, supra note 36, at 259.

61 Surviving the Meltdown: Rotberg on Risk, INT'L Frn. REv., Nov. 28, 1987, at 727. 
risk." 62 This risk is present even in the simple world of the perfectly complementary savings and loan and consumer finance company swaps. Credit risk is inherent in being a swap dealer. No matter how lucky it is in finding parties whose needs are complementary or how clever it is in its hedging, the swap dealer is always exposed to the possibility that its customer will default. It is this kind of risk with which the BIS Accord was primarily intended to deal and to which we now turn. ${ }^{63}$

The credit risk faced by a bank on a given swap is most easily analyzed by examining two related concepts, "current exposure" and "potential exposure." The "current exposure" of the bank on a swap as of any date refers to the extent to which the bank would suffer if its customer were to default on the swap on that date. If, for instance, interest rates were to rise and the finance company (the floating rate payor) breached, the bank would lose its source for the floating rate payments which it needs to make payments to the savings and loan pursuant to the mirror swap. Indeed, since the bank will pay more on the mirror swap than it receives from the savings and loan the bank will lose money acting as swap dealer. The bank has lost the benefit of the bargain with the finance company at a time when the finance company was losing its bet with the bank.

A rough approximation of the bank's loss would be the cost for the bank of replacing the defaulted swap with its economic equivalent. That is, the bank's damages are the cost of making

62 See Financial Accounting Standards Board, Proposed Statement of Financial Accounting Standards: Disclosures of Information about Financial INSTRUMENTS With OFF-BaLANCE-SheET Risk aNd Financial INSTRUMENTS WITH Concentrations of Credit Risk 3 (July 21, 1989).

63 Cf. supra note 51 (describing how some financial institutions avoid this "guarantor" role and hence credit risk).

This Article does not discuss the effect on bank risk of diversification within swap portfolios or diversification of bank activities generally. See, e.g., FIRST INTERSTATE Bancorp, Technical Supplement [hereinafter First Interstate Technical SUPPLEMENT] (attachment to Letter from James F. Burns, Jr., Executive Vice President, First Interstate Bancorp to William W. Wiles, Board of Governors of the Federal Reserve System (May 7, 1987)) (illustrating effects of failure to capture interest and exchange rate diversification effects within a swaps portfolio on estimate of credit exposure); Technical Paper: Average Potential Exposure vs. Near-Maximum Potential Exposure for Interest Rate Swap Portfolios (attachment to Letter from Michael P. Esposito, Executive Vice President and Chief Financial Officer of the Chase Manhattan Corporation, to William W. Wiles, Board of Governors of the Federal Reserve System (June 1, 1987)) (illustrating how portfolio effects can complicate measurement of potential credit exposure of swaps); Litan, Evaluating and Controlling the Risks of Financial Product Deregulation, 3 YALE J. ON REg. 1, 10-19 (1985) (discussing how financial institutions can reduce risk through diversified portfolios of various banking and non-banking activities). 
arrangements to pay $\$ 11.4$ million a year in return for Prime on a $\$ 100$ million notional amount for the remaining life of the original swap. If the original swap is a fairly common one - a plain vanilla swap - the bank could simply buy a swap from another swap dealer with the precise economic characteristics as the original swap with the finance company. ${ }^{64}$ In contract terms, the bank can simply enter into a cover transaction and ask the finance company to pay the cost of cover ${ }^{65}$ This lump sum amount - typically called the "mark-tomarket" value - would be the measure of damages suffered by the bank on default by the finance company.

The current exposure of the bank to the finance company is thus approximately equal to the mark-to-market value of the swap at that time. As one would expect, the more interest rates increase from commencement of the swap, the more "credit" the bank is effectively extending to that party and the more the "mark-to-market" amount will be.

Of course, if interest rates were to remain stable, or if they were to drop, a default by the finance company'would expose the bank to little or no credit risk. Indeed, if interest rates were to drop, the bank would not have to pay a swap dealer anything to enter into the replacement swap. Instead, a swap dealer would be willing to pay the bank to enter into a swap on what would be extremely favorable terms. Thus, if interest rates drop, the finance company is effectively extending "credit" to the bank rather than the other way around; the "mark-to-market" value would be a negative number.

The "potential exposure" of the bank on a swap as of any date does not refer to the credit risk to which the bank is actually subject on that date. Instead, the term refers to the extent to which the bank would be exposed to its customer if interest rates or exchange rates were to move in the wrong direction. Broadly speaking, the current exposure on a given day can be analogized to the temperature on

64 See, e.g., International Swap Dealers Association, User's Guide to the STANDARd Form AgreEments 8-11 (1987) (discussing how loss calculated in standard documentation when one party to a swap defaults); see also S. Henderson \& J. Price, supra note 36, at 101-121; Gooch \& Klein, Damages Provisions in Swap Agreements, INT'L Fin. L. Rev., Oct. 1984, at 36; Henderson, Termination Provisions of Swap Agreements, INT'L FIN. L. REv., Sept. 1983, at 22.

65 For example, assume that Prime has risen to $20 \%$ at the time of default by the finance company. No swap dealer would be willing to enter into a swap paying Prime on $\$ 100$ million in return for a payment of $\$ 11.4$ million, the payment terms of the original swap between the bank and the finance company. The bank would have to sweeten the deal with a lump sum payment, and then attempt to recover this payment from the finance company. 
that day. The potential exposure on that day would reflect just how hot it might reasonably get in the future.

Clearly, it is much easier to state what the temperature is now than to predict tomorrow's high temperature or even to express that prediction in a simple way. The meteorologist can determine with absolute certainty what the temperature is at the moment. On the other hand, in order to predict what the high may be the following day, she must develop a model of weather systems. However sophisticated her modelling, she cannot state what the precise high will be, but will, at best, only be able to give a range of statistical probabilities. $^{66}$

Similarly, current exposure as to a plain vanilla swap is easy to quantify. Phoning a swap dealer to see what it would charge is analogous to looking at a thermometer. ${ }^{67}$ Potential exposure, however, is not as easy to determine or express.

The modeling is not only technically difficult but is susceptible to personal judgments. Such models depend on a wide variety of assumptions, ranging from assumptions about how interest rates and exchange rates fluctuate to assumptions about how these fluctuations relate to the risk of default on the part of bank customers. ${ }^{68}$ Quanti-

66 See Note, Social Science Statistics in the Courtroom: The Debate Resurfaces in McCleskey v. Kemp, 62 Notre Dame L. Rev. 688, 695 (1987) (describing the measures of central tendency and the measures of dispersion).

67 The only major problems likely to emerge from measuring current exposures pertain to "exotic" swaps, for which only a limited number of swap dealers may be willing to give quotations. Thus, in the early days of the swap market, when quotes were less available, there was reluctance to use a mark-to-market concept in case of counterparty default. Even now, there are provisions for alternative damage remedies in case a sufficient number of reliable quotations is unavailable. See INTERNational Swap Dealers Association, supra note 42, at 12; cf. infra notes 23233 and accompanying text (concerning possible mispricing of certain hedging products by major money center bank).

68 See, e.g., British Banker's Association, Convergence of Capital Adequacy IN THE UK aNd US: Memorandum on the Consultative Papers Issued bY the BanK of ENGland and the U.S. Federal AUthorities 8-9 (May 1987)[hereinafter 1987 BBA MEMORANDUM] (criticizing as overly conservative the proposed uses of "stringent" confidence limits and data on volatilities observed during the early 1980s); First Interstate Technical Supplement, supra note 63, at 5 (describing how small changes in United States dollar interest rate volatility drastically affect swap exposure); Ardalan \& Seigel, supra note 57, at 82-83 (asserting a vast distinction between the use of statistical data from the 1973 to 1980 period and the use of such data from the 1978 to 1985 period).

The methodology ultimately used by regulators to assess risk is not clearly set forth in the BIS Accord. Inferences can be drawn from a preliminary model released by the Federal Reserve Board and the Bank of England in March 1987, the comment letters filed in response thereto, and the regulations eventually implementing the BIS Accord. See FRB/BOE Credit Exposure Memorandum, supra note 57. 
fication of these assumptions involves answering questions that do not lend themselves to scientific resolution. ${ }^{69}$

Whatever the models and assumptions used, the potential exposure is more difficult to express than the current exposure. The current exposure of a bank on a swap is captured quite well by a single number, the mark-to-market value of the swap. The potential exposure on the same swap is intended to give some sense as to how high the exposure might reach; if the potential exposure on a swap is characterized by a single number, implicit in that number is some judgment as to the acceptable level of statistical improbability. ${ }^{\mathbf{7 0}}$

As this discussion illustrates, the credit risks assumed by a bank entering into a swap are quite different from those assumed when making a traditional variable rate term loan. ${ }^{71}$ With such a loan, the maximum amount the bank could lose at any moment is identifiable and constant in magnitude: even in the worst case scenario, the most the bank can lose if the borrower defaults is the principal amount. ${ }^{72}$

69 For good discussions of the subtleties of potential exposure, see First Interstate Technical Supplement, supra note 63; Garbade, An Appreciation of the Analysis of Credit Exposure on Single-Currency (U.S. Dollar) Fixed-floating Interest Rate Swaps in Treatment of INTERest Rate and Exchange Rate Contracts in the Risk Asset Ratio and Potential Credit Exposure on Interest Rate and Exchange Rate RELATEd INSTRUMENTS (Mar. 1987) (attachment to Letter from George J. Vojta, Executive Vice President, Bankers Trust Company, to William W. Wiles, Board of Governors of the Federal Reserve System (May 12, 1987)); Letter from Donald S. Howard, Executive Vice President, Citicorp, to William W. Wiles, Board of Governors of the Federal Reserve System, Appendix I (June 1, 1987); Comments on Federal Reserve Board Proposed Rulemaking, Docket No. R-0567: Incorporation of Credit Risks From Interest and Exchange Rate Contracts in Risk Based Capital Measure (attachment to Letter from John F. Kooken, Vice Chairman \& Chief Financial Officer, Security Pacific Corporation, to William W. Wiles, Board of Governors of the Federal Reserve System (May 29, 1987)).

Analogous problems can arise in the technological decisionmaking context. See, e.g., McGarity, Substantive and Procedural Discretion in Administrative Resolution of Science Policy Questions: Regulating Carcinogens in EPA and OSHA, 67 GEo. L.J. 729, 732 (1979) ("The proceedings are characterized by very few 'hard facts,' many assumptions and inferences, large uncertainties, and the unavoidable exercise of policy judgment.").

70 Cf. Financial Accounting Standards Board, Proposed Statement of Accounting Standards: Disclosures Abouti Financial Instruments 17 (Nov. 30, 1987) (defining the concept of reasonably possible credit loss).

71 See Ferron \& Handjinicolaou, supra note 41, at 135-36 (discussing credit risk differences between swaps and traditional variable rate bank loans).

72 Strictly speaking, the bank also could lose accrued interest and unreimbursed enforcement costs and, possibly, suffer from the impact of such a default on the bank's overall mix of assets and liabilities. In addition, under certain narrow circumstances, the bank may actually find itself having liability to the borrower or to others from having entered into a lending transaction. See, e.g., 42 VAND. L. Rev. 855-983 (1989) (articles on various aspects of lender liability); Quentel, The Liability of Finanical Institutions for Hazardous Waste Cleanup Costs Under CERCLA, 1988 WIS. L. 
Using swap terminology, the "current exposure" on a loan is fixed in magnitude and is equal to the "potential exposure" on the loan.

In contrast, the current exposure of a swap can vary from hour to hour as interest rates and exchange rates fluctuate. The potential exposure is more difficult to assess and to express. The potential exposure will depend on the forecasting model, the assumptions underlying the model, and, if a single number is used to express the potential exposure, the level of statistical improbability selected.

\section{Model Twins: The Swap and the BIS Accord}

\section{A. Swaps: Uses and Growth}

Introduced in quite some secrecy in the late 1970s, swaps became vital to corporate and international finance in the $1980 \mathrm{~s}^{73}$ With disclosure in 1981 of some of the particulars of a currency swap between IBM and the World Bank and the disclosure in 1982 of the details of an interest rate swap involving Deutsche Bank Luxembourg, the swap soon flourished. ${ }^{74}$ In two years, the swap market "shot from infancy to middle-age."75. The figures as to interest rate swaps are illustrative. As of the end of 1982, $\$ 3$ billion of interest

REv. 139 (describing how lenders can face potential liability for their borrowers' hazardous waste cleanup costs).

73 Some observers speculate that the first swap was a currency swap in August 1976 between clients of Continental Illinois Limited and Goldman Sachs. In an effort to protect the proprietary nature of the product, the parties apparently shunned publicity, See S. Henderson \& J. Price, supra note 36, at 4; see also $A$ Back Door to Fixed Rate Loans, Bus. WK., Dec. 13, 1982, at 85 (discussing the closely guarded nature of swaps); Hammond, supra note 36, at 66 ("[I]solated examples of swap agreements date back to the mid-1970s.").

There is some dispute over when the first interest rate swap was entered into. See, e.g., S. Henderson \& J. Price, supra note 36, at 4 (stating that the first interest rate swap occurred in 1981); R. Kopprasch, J. Macfarlane, D. Ross, \& J. Showers, supra note 36, at I (suggesting that the first interest rate swap occurred in the late 1970s). Moreover, it is not clear who invented or first introduced the interest rate swap. See McGough, Scratch My Greenback, Forbes, July 18, 1983, at 129 ("Somebody invented [the interest rate swap] . . . and by three cocktail parties later everybody on The Street had invented it." (quoting First Boston's Dexter Senft)); cf. First Swap, Euromoney: A Special 20th Anniversary Supplement, June 1989, at 246 ("Who started swaps, and when? There are many claimants for that particular honour, and the truth is certainly obscure.").

74 See S. Henderson \& J. Price, supra note 36, at 4-5; Price, Keller, \& Neilson, Exchanges of Borrowings, in Swap Financing Techniques 17 \& 30-31 (B. Antl ed. 1983); see also Shirreff, supra note 4 , at 60 (discussing the initial swaps). For a discussion of the importance of the World Bank's decision to enter into a currency swap, see Tait, It Takes Two to Tango, Euromoney, Feb. 1983, at 75, 77.

75 Shirreff, Swaps: Managing the Future, Euromoney, Oct. 1984, at 202 (quoting Bank of America's Richard Davis). 
rate swaps were outstanding: ${ }^{76}$ two years later, this had grown to $\$ 90$ billion. ${ }^{77}$ By the end of 1988, one trillion dollars of interest rate swaps were outstanding. ${ }^{78}$

While the phenomenal rate of growth is difficult to explain, ${ }^{79}$ the popularity of the swap was not entirely surprising. The extraordinary interest rate and exchange rate volatility of the past decade increased the demand for hedging products. As a hedging device, the swap was outstanding in a number of respects. Not only did swaps have the technical virtue of providing hedging on a long term basis, ${ }^{80}$ they also quickly became user-friendly and inexpensive. Newly aggressive financial institutions looking for business would not only show puzzled corporations how to protect themselves against these risks by using swaps but would also tailor the amount, type, and term of the swap to the precise needs of the customer. ${ }^{81}$ The benefits of such guidance and custom-made hedging would often trump such alternatives as publicly-traded options and futures with their standardized terms and conditions. Such tailor-made hedges became increasingly inexpensive to bank customers with increasing standardization of legal documentation and price competition among swap dealers. ${ }^{82}$

The fact that the swap proved to be useful beyond its simple

76 See Rogers, supra note 5 , at 397.

77 See id.

78 See ISDA Press Release, supra note 6 . The figures as to currency swaps and closely allied products like "caps" and "floors" are suggested by supra notes 3 \& 6 .

One major swaps dealer claims that "[f]rom their origins in the early part of this decade, the swap markets have grown at a faster annual rate than any other area of the financial market both before and since." Westpac, Interest Rate and Currency Swaps: A Presentation 1 (June 1988) (on file with the University of Pennsylvania Law Review).

79 See Smith, Smithson \& Wakeman, supra note 36, at 34.

80 See When the Swap Meets the Option, Euromonex, Apr. 1989 (supplement), at 26 ("If you want to hedge currencies long term, swaps are the only instruments liquid out to 10 years.").

81 Cf. For the Client, A Black Box or Something Transparent?, Euromoney, Apr. 1989 (supplement), at 23 (development of teams with time, skills and computer power to analyze clients' problems). The deregulation of capital markets, the attendant globalization of finance, and competition from the internal staff of their own corporate clients all seemed to contribute to the growth of entrepreneurial spirit within major financial institutions. See Germany \& Morton, supra note 3, at 743; Sillem, A Central Bank View of Innovations in the Financial Markets, WORLD BANKIng, Nov.-Dec. 1986, at 12 \& 16; Stillit, What Are the Limits of Disintermediation?, CoRP. Fin., Oct. 1986, at 67.

82 For a discussion of efforts to standardize swap legal documentation, and of the increasing use of swap master agreements, see British BANKERs' Association, INTEREST RATE Swaps (Aug. 1985) (usually referred to as "BBAIRS" terms); Cunningham, Swaps: Codes, Problems and Regulation, InT'L Frn. L. Rev., Aug. 1986, at 
hedging uses also contributed to its popularity. As capital markets worldwide were deregulated, arbitrage opportunities emerged whereby the swap could be employed to take advantage of subtle differences in capital markets. This technique became the key to many debt issuances, saving the astute borrower significant interest costs. $^{83}$ By the end of 1986 , some $70 \%$ of all new international bond issues were "swapped out." 84 The swap has also proven to be very useful in creating other financial instruments. ${ }^{85}$

The exponential growth in the speed and sophistication of computer hardware and software in the 1980s went hand in hand with the growth of the swaps market. Advanced computers facilitated the computations necessary to help banks develop complex new types of swaps and manage their payment streams and their hedging activities. $^{86}$

Finally, in the early years, participants believed that few regulatory requirements existed at either the product level or at the financial institution level. ${ }^{87}$ Any financial institution that decided it had

26; Henderson, supra note 22, at 385-87; Selby, Standardizing Caps and Collars, INSTITUTIONAL INVESTOR, Apr. 1989, at 28.

For a discussion of the decreasing profit margins of swap dealers, see Weiner, Bankers Cite Edge over Rivals in Competitive Swaps Market, AM. Banker, Apr. 6, 1988, at 1 (tracing decline of bid-offer spread on a five-year plain vanilla swap from 22 basis points in 1983 , to 12 basis points in 1984 , and eventually to a mere 10 basis points in the $1985-1988$ period).

83 See supra notes 44, 53-55 and accompanying text. But see supra note 45 .

84 See Ebert, supra note 4, at 23-24; see also A Little Local Difficulty, EсоNomist, Mar. 18, 1989, at 84 ("Few Eurobonds are launched without at least one swap behind them to give the borrower cheaper or in some way more desirable funds.").

85 See Lee, Why Investors Are Missing Profits, Euromoney, Apr. 1989, at 56; Smith, Smithson \& Wakeman, supra note 36 , at 43 ; see also supra note 44 .

86 See, e.g., Backstrom, supra note 26, at 83 (suggesting that no matter how complex the swap business of a particular bank, a need for computer technology exists); A Bank Has to Know Its Way around the Globe, EuromonEY, Apr. 1989 (supplement), at 5 (discussing the resources such as computer technology that a bank must possess in order to act as a risk manager); Selling Fridges to Eskimos, supra note 4, at 55 (discussing the types of computer hardware and software being used by the banks in the swap industry); supra note 10.

87 See Regulators Expected to Require More Disclosure, Regulation of Swap Market, Wash. Fin. Rep. (BNA) No. 14, at 531 (Apr. 7, 1986) (quoting an officer of an investment bank as saying that swaps are "one of the few major unregulated financial instruments"); Raiding of the Rate Swappers, N.Y. Times, Jan. 14, 1986, at D1, col. 3 ("Clearly, one of the reasons why this [swap] market has grown so rapidly is because it's unregulated." (quoting Charles M. Lucas of the Federal Reserve Bank of New York)). For a discussion of regulation in the early years of the swap market, see infra note 88.

In more recent years, regulators have been paying increasing attention to the swap market. For instance, in 1987, the Commodity Futures Trading Commission took actions which suggested it might ultimately require many swaps to be traded on 
the contacts and the expertise could choose to be a swap dealer. Neither capital adequacy requirements nor deposit insurance premiums applied to bank swap activities. Nor did regulators prescribe the terms and conditions of swap agreement. It was virtually a free market. It was too good to last.

\section{B. The BIS Accord and the New Generation of Financial Regulation}

\section{The Rationale for Regulation}

Soon after the existence of swaps became public knowledge, regulators began considering possible courses of action. In the United States, commodities and securities regulators refrained from intervening in the offer, sale or trading of the products. ${ }^{88}$ It was U.S.

federally designated exchanges and otherwise subject them to its jurisdiction. See Young \& Stein, Swap Transactions under the Commodity Exchange Act: Is Congressional Action Needed?, 76 GEO. L.J. 1917, 1918-20 \& 1943-45 (1988). To the delight of the swaps industry, in July 1989 the Commodity Futures Trading Commission recognized a broad non-exclusive safe harbor; if a transaction comes within the safe harbor, the Commission will take no action to regulate it. The safe harbor can be met by the vast majority of swap transactions. See Policy Statement Concerning Swap Transactions, 54 Fed. Reg. 30694 (1989) [hereinafter CFTC Swaps Policy Statement]; Dorff, The CFTC's Swaps Policy Statement: A Safe Harbor for Off-Exchange Instruments, FIA Review, Sept.-Oct. 1989, at 14; see also infra notes $201 \& 215$ and accompanying text (discussing commodity swaps).

For examples of other recent regulatory or quasi-regulatory actions in the United States taken outside of the capital adequacy area, see FFIEC Interest Rate Swap Proposal Opposed by Bankers and Accountants, 52 Banking Rep. (BNA) 320, 321 (Feb. 6, 1989); Saunders, "It's the Right Thing to Do," Forbes, Apr. 17, 1989, at 104; Weiner, '89 Will Bring Closer Scrutiny of Swap Products: Regulators, Tax Authorities Concerned over Implications for Banking Industry, AM. BANKER, Jan. 3, 1989, at 3; $f$. THE 1987 LONDON Swaps SEminar, supra note 26, at 90-92 (Bank of England official referring to three United Kingdom regulators with swap responsibilities); WhOLESALE MARKETs, supra note 51, at 38-44 (1988) (Bank of England establishing general standards for swap market); Morton \& Creamer, FSA: The Scheme for Derivative Instruments, INT'L FIN. REv., Oct. 1989, at 30, 30-31 (describing applicability of Britain's Financial Services Act 1986 to swaps and other financial products).

88 The most notable actions on the part of commodities regulators in this area occurred in 1987, when the Commodity Futures Trading Commission took actions which seemed to suggest that it might ultimately require many swaps to be traded on federally designated exchanges, and in 1989, when it effectively elected not to regulate the vast bulk of swap transactions. See supra note 87 and infra notes 201, 215-16 and accompanying text. The most notable action taken by securities regulators in this area was an undated, unpublished, and unissued "no-action letter" pertaining to the "net capital" of a broker dealer. See SEC Considering Interest Rate Swap Guidelines Opposed by Industry, SEC. WEEK, Mar. 11, 1985, at 3; Taylor, Interest Rate and Currency Swaps, 2 Rev. FIN. Servs. Reg. 107, at 109 (1986); Taylor, Regulatory Valuation of Swap Exposure, in INTEREST RATE AND CuRrency Swaps 1986, at 369 \& 
commercial bank regulators, often in close coordination with their foreign counterparts, who were to become the dominant actors.

Why should governments regulate the affairs of commercial banks at all? Governments are not supposed to intervene in the success and failure of private firms. Individual successes and failures are part of the proper functioning of a free enterprise system in which the race goes to the swift. ${ }^{89}$ Yet, in virtually all western industrialized countries, the banking industry is more heavily regulated than any other, and virtually all economists believe that the safety and soundness of banks is sufficiently important to warrant such intrusion..$^{90}$

Two arguments for governmental intervention are especially prominent. The first relies on application of the basic "externalities" argument for government intervention. Proponents believe that failure of a bank has social costs which far exceed the private costs of such failure; the "externalities" from failure are higher than those arising from the failure of a typical industrial enterprise. Based on experience from the Depression, some argue that the failure of an individual bank, especially a large bank, could lead to bank runs throughout the economy and ultimately lead to a disastrous financial panic. ${ }^{91}$ Other economists focus on the fact that widespread bank

453-55 (D. Cunningham chairman 1986) (reprinting the draft no-action letter); infra note 149 .

For background on the early history of swap market regulation and the possible application of securities and commodities laws to swaps, see Dutt, Interest Rate Swaps Face Scrutiny by Commodities Regulators, CoRP. Financing WEek, Sept. 16, 1985, at 1; Gilberg, Regulation of New Financial Instruments Under the Federal Securities and Commodities Laws, 39 VAND. L. Rev. 1599 (1986); Henderson, US Authorities Decide Not to Issue Ruling, Int'l Banking L. Bull., Feb. 1985, at 55; Klein, Interest Rate and Currency Swaps: Are They Securities?, INT'L Fin. L. Rev., Oct. 1986, at 35; McGough, supra note 73, at 129; Olander \& Spell, supra note 40, at 21; Taylor, Interest Rate and Currency Swaps, 2 Rev. Fin. Serv. Reg. 107 (1986).

89 See Macey \& Miller, Bank Failures, Risk Monitoring, and the Market for Bank Control, 88 Colum. L. REv. 1153, 1155 (1988) ("In a market economy, when an enterprise fails, the resources previously devoted to a firm will find other, more efficient uses.").

90 See R. Dale, The Regulation of International Banking 53 (1986).

For discussion of the full range of reasons for governmental intervention as to the soundness of banks, see, e.g., Clark, The Soundness of Financial Intermediaries, 86 YALE L.J. 4, 10-26 (1976); Macey \& Miller, supra note 89, at 1155-65.

91 See Corrigan, $A$ Framework for Reform of the Financial System, Fed. Reserve Bank New YoRk QUaRT. Rev., Summer 1987, at 1, 3; Garten, Banking on the Market: Relying on Depositors to Control Bank Risks, 4 YALE J. ON REg. 129, 160-63 (1986); Wall, Regulation of Banks' Equity Capital, Econ. Rev., Nov. 1985, at 4-5. But see G. BENSTON \& G. Kaufman, Risk and Solvency Regulation of Depository Institutions: Past Policies ANd Current Options 18 (1988); Fischel, Rosenfield, \& Stillman, The 
failures could cause the money supply to drop unexpectedly, thereby causing unemployment to rise and output to fall. ${ }^{92}$

The second set of reasons favoring bank regulation, a variation on the externalities argument, arises from the existence of the explicit or implicit governmental safety net for banks. ${ }^{93}$ Because of the existence of governmental deposit insurance, the costs of a bank failure would be borne by the healthy institutions paying premiums or, if the insurance funds are depleted, taxpayers. Deposit insurance premiums, being fixed at a flat rate rather than adjusted for the risks being taken by the individual financial institution, give financial institutions incentives to take undue risk. Decisions that major money center banks were simply too large to be allowed to fail may similarly encourage shareholders and managers to engage in excessive risktaking because the costs of failure would be borne by third parties. ${ }^{94}$

Regulation of Banks and Bank Holding Companies, 73 VA. L. Rev. 301, 310-11; Macey \& Miller, supra note 89, at 1157 .

A version of the externalities argument helped motivate the $\$ 300$ billion congressional rescue of the savings and loan industry in August 1989. See Hershey, Savings Bill Expected to Cut Premium Rates on Deposits, N.Y. Times, Aug. 8, 1989, at 1, col. 2 ("Over 30 years, the plan will cost about $\$ 300$ billion, with taxpayers picking up $\$ 225$ billion and the healthy portion of the industry paying the rest."); Nash, After Savings and Loan Rescue, Lawmakers Go Home, N.Y. Times, Aug. 6, 1989, at 14, col. 3 (quoting an observer who contended that "[i]f at any time along the way the Congress had wavered at all on making good on the deposits, you would have seen massive runs from banks and S. \& L.'s"').

92 See Fischel, Rosenfield, \& Stillman, supra note 91, at 311.

93 See Macey \& Miller, supra note 89, at 1162-63. For other discussions of the moral hazard justification for bank regulation, see UNITEd STATES GENERAL Accounting Office, Deposit Insurance: Analysis of Reform Proposals (1986); G. Benston \& G. Kaufman, supra note 91, at 23-26; Fischel, Rosenfield, \& Stillman, supra note 91, at 314-16; Goodman \& Shaffer, The Economics of Deposit Insurance, 2 YALE J. ON REg. 145 (1984); Litan, supra note 63, at 20-21; Lovett, Moral Hazard, Bank Supervision and Risk-Based Capital Requirements, 49 Oнго Sт. L.J. 1365 (1989); Macey \& Garrett, Market Discipline by Depositors: A Summary of the Theoretical and Empirical Arguments, 5 YALE J. ON REG. 215 (1988); see also infra note 121.

94 The "moral hazard" argument implicitly suggests that bank management engages in risk-taking that is excessive from the social standpoint despite the existence of a number of factors militating in favor of very risk-averse behavior. $C f$. Litan, supra note 63 , at 21-22 (describing reasons why bank managers may wish to avoid excessively risky undertakings); Tussing, The Case for Bank Failure, 10 J.L. Econ. 129, 130-31 (1967) (referring to studies a generation ago which found that banking firms were "dominated by submissive, nonaggressive, security-oriented personalities").

Governmental deposit insurance has spawned an additional, related argument for bank regulation. The argument is that the government, by providing deposit insurance, is a stakeholder in the bank and, as such, has a right to protect its interests; " $[t]$ he federal deposit insurance system, by guaranteeing deposits, in essence takes on the role of a bank liability holder and has an interest in bank capital similar to that of private liability holders in an uninsured firm." Furlong \& Keeley, Bank Capital 
This moral hazard problem contributed to Congress including an express limitation on the ability of savings and loans to invest in "junk bonds" in the August 1989 legislation bailing out the savings and loan industry. ${ }^{95}$

Both of these arguments in favor of bank regulation generally apply to the financial innovation activities of banks. Because of the difference between social and private costs of failure and because of the governmental safety net, banks acting in the best interests of shareholders would have the incentive to knowingly incur more risk as to financial innovations than society would want them to take.

This problem would be worse - and the need for governmental intervention heightened - if banks were in fact taking on even higher levels of risk. Regulators believed that this was occurring. First, some regulators believed that the "off-balance sheet" nature of the new financial instruments might encourage banks to assume more risks than would be the case if the full nature and extent of the risks were fully understood by and disclosed to the market. ${ }^{96}$ Second, some regulators believed that financial institutions were involved in complex and exotic instruments but did not understand the risks the instruments posed to the financial institutions themselves. In 1985, one official at the Federal Reserve Bank of New York highly active in the financial innovations area stated that he was "convinced that no one at the top levels" of the banks entering into swaps and other new financial products had a "thorough understanding of the risk proper-

Regulation and Asset Risk, in Fed. Reserve Bank San Francisco Econ. Rev., Spring 1987, at 20, 22; see also infra note 121 .

95 See Financial Institutions Reform, Recovery, and Enforcement Act of 1989, Pub. L. No. 101-73, § 222, 103 Stat. 183, 269-73 (1989) [hereinafter FIRREA].

FIRREA has directed the Secretary of the Treasury to explore the feasibility of establishing variable rate deposit insurance as part of a study of the federal deposit insurance system. See FIRREA, Pub. L. No. 101-73 at $\S 1001(\mathrm{a})-(\mathrm{b}) ;$ cf. Litan, supra note 63 , at $21 \& 39-40$ (concerning difficulties of establishing variable rate deposit insurance as a means of solving moral hazard created by current deposit insurance system); Avery \& Belton, A Comparison of Risk-Based Capilal and Risk-Based Deposit Insurance, ECON. REV., Winter 1987, at 20 (comparing risk-based capital scheme with variable rate deposit insurance); infra note 266 (describing, among other things, difficulties of governmental insurance schemes).

96 See, e.g., Cross REPort, supra note 3 , at 231 ("The absence of widely accepted and recognised accounting practices ... with respect to off-balance-sheet items ... raises the issue of whether firms have been willing to assume more risks than if their positions were disclosed and understood by the market."); see also Andrews \& Sender, Off Balance Sheet Risk: Where is it Leading the Banks?, InSTITUTIONAL InvESTOR, Jan. 1986, at 75, 76 ("Has the attention paid to simple capital-asset ratios driven risks off balance sheet - and is off balance sheet also out of mind?" (quoting Paul Volcker)). 
ties of these instruments."97 Other regulators focused on pricing at levels which seemed to be below those justified by the risks assumed and on the failure to adjust the swap prices for the creditworthiness of bank customers. ${ }^{98}$ Sudden collapses in the markets for various exotic securities and massive losses by the likes of Merrill Lynch in trading exotic securities exacerbated these fears. ${ }^{99}$

\section{Constraints on Unilateral Intervention and the Emergence of the BIS Accord}

Bank regulators chose not to develop a regulatory system specifically addressed to these products. Instead they took advantage of,

97 Hiltzik, Banks Enter New World of High Risk, L.A. Times, Oct. 27, 1985, pt. 5, A1, col. 6; id. at D6, col. 1 (quoting Charles Lucas of the Federal Reserve Bank of New York); see also Sillem, supra note 81, at 16 (quoting another central banker who said "[i]t is doubtful whether top management is always fully aware of the risks assumed by financial specialists. The situation becomes even more alarming if the remuneration of these specialists is partly linked to the financial results achieved by them"); cf. Cooke, supra note 30 ("I am sure I am not alone in expressing the hope that senior management really is on top of the use made of these sophisticated" techniques. Perhaps I may be excused from evidencing a little of the supervisors' twitch on this subject. Senior management and supervisors have to work hard to keep up with these developments.").

Stanley Ross, managing director of Deutsche Bank Capital Markets, recently made the following entry for 7:15 a.m. in his daily journal:

Directors' meeting linked to head office. Swaps specialist propounds complex multistage swap. Entire table nods wisely. Wonder if all as confused as I. Again think, "This is a young man's game."

Ross, Bright Sun, Clear Seas, Blue Skies . . ., Euromoney: A Special 20th ANniversary SuPPLEMENT, June 1989, at 263.

98 See Cross Report, supra note 3, at 3; Ireland, RJR bids focus attention on swap credit risk, Corp. Fin., Dec. 1988, at 13. But see Smith, Smithson, \& Wakeman, supra note 36 , at 43 ("We see no convincing evidence that swaps are mispriced.").

99 See Crabbe, Perpetual Commotion, Euromoney, Jan. 1987, at 5; Spragins \& Farrell, The Big Loss at Merrill Lynch: Why It was Blindsided, Bus. WK., May 18, 1987, at 112 (stating that the investment bank's April 1987 trading loss of $\$ 250$ million resulted in part from the inability "to understand and manage the risks of the complex business it is in"); $A$ Third of a Billion Dollars Wiser at Merrill, InSTITUTIONAL Investor, Aug. 1988, at 136; see also OfFice of THE Comptroller of the CuRRency, The Director's Book: The Role of a National Bank Director 31 (1987) ("Management should be fully conversant in [highly technical risk reduction techniques, such as swaps, futures, and options] before it engages in them."); Shale, The great risk-management systems failure, EUROMONEY, Feb. 1989, at 66, 67 (quoting a former head of equity-block trading for a major investment bank as saying "[m]anagement is simply not spending enough time on risk-management"); of. Klynveld Peat Marwick Goerdeler, Global Capital Markets 33 (1988) (stating that sixty percent of large financial institutions surveyed were not satisfied as to the adequacy of their risk management systems); The 1987 London Swaps Seminar, supra note 26, at 92 (comments of the Bank of England's Carol Sergeant on the importance of "systems"). 
and contributed to, the momentum that had been building since the 1970 s for internationally-coordinated efforts at enhancing the safety and soundness of major banks generally. This momentum consisted of three related elements: (1) regulation on an international basis; (2) the emergence of a massive movement in favor of capital adequacy standards as a solution to perceived problems in the safety and soundness of banks; and (3) incorporation of the regulation of swaps and related hedging products into this movement. Each of these elements is examined in turn.

Regulation of bank activities on an international basis helps resolve a fundamental problem of international public goods. A safe and sound international financial system has elements of what economists would refer to as a "public good." 100 Because it is impossible to exclude those who do not pay for a pure public good from also benefiting from that good, each party will have incentives not to pay its fair share of the benefit. Deterrence against enemy aggression offers a classic illustration of a public good: everyone benefits from such deterrence, even an individual who refused to pay taxes. Because each individual would be protected if everyone else contributed their share of national defense, there are likely to be "free riders." If each person acts rationally from his own point of view, far too little will be spent on defense from the perspective of society as a whole.

The maintenance of a healthy financial system for the western industrialized countries has similar public goods elements. Particularly in view of the explosive growth in interdependence among capital markets in the past decade or two, ${ }^{101}$ each country has an interest in the maintenance of a healthy international financial system and is

100 For concise introductions to public goods issues, see R. MUsGrave \& P. Musgrave, Public Finance in Theory and Practice 49-80 (2d ed. 1976); E. Stokey \& R. Zeckhauser, A Primer for Policy ANalysis 305-308 \& 315-16 (1978); Conybeare, International organization and the theory of property rights, 34 INT'L ORG. 307, 327 (1980); Sandler \& Cauley, On the Economic Theory of Alliances, 19 J. Confuict Res. 330 (1975).

A body of literature implicitly applying these theories to the international regulation of bank safety is emerging. See R. Bryant, InTERnational Financial INTERMEDIATION 128-50 (1987); B. CoHEN, IN WhOSE INTEREst? INTERNATIONAL Banking and American Foreign Policy 303 (1986); R. Dale, supra note 90, at 17172; Lichtenstein, Introductory Note, Bank for International Settlements: Committee on Banking Regulations and Supervisory Practices' Consultative Paper on Proposals for International Convergence of Capital Measurement and Capital Standards, 27 INT'L LEGAL Mat. 524 (1988).

101 See Spero, supra note 30, at 115 (referring to the "dramatic increase in international market activity" during the 1980s); supra notes 15, 24-26 \& 81 . 
willing to contribute in some fashion to its maintenance. A country may, for instance, be willing to impose controls on its own banking institutions to further this international goal. However, since the benefits of a healthy financial system will, to a certain extent, benefit all industrialized countries whatever their individual contribution to such a system, each country may be tempted to free-ride to a certain extent on the efforts of other countries. To further complicate matters, while the regulators of all countries have an interest in international stability, they also have an interest in minimizing the cost to their own nation's banks. This latter tendency may result in a race towards laxity in regulation in an effort to give an advantage to home institutions. ${ }^{102}$

International coordination was needed to prevent this kind of shirking by individually rational but internationally troublesome regulatory behavior. With the increasing globalization of the capital markets, this became more of a problem. A sea change occurred because of the 1974 failures of West Germany's Bankhaus Herstatt and the Franklin National Bank of New York. ${ }^{103}$ In December 1974, the central bank governors of the Group of Ten countries and Switzerland established a committee under the auspices of the Bank for International Settlements to promote international cooperation in the monitoring and supervisory coverage of international banking activities. This, the Committee on Banking Regulations and Supervi-

102 See Risk-Based Capital Requirements for Banks and Bank Holding Companies: Hearing Before the Subcomm. on General Oversight and Investigations of the House Comm. on Banking, Finance and Urban Affairs, 100th Cong., 2d Sess. 5 (1988) (statement of William Taylor, Division of Banking Supervision and Regulation, Federal Reserve Board) ("[W]e simply cannot ignore the impact of differing regulatory standards on U.S. banks' ability to compete worldwide. More consistent supervisory standards among countries can contribute to greater competitive equality and, in the long run, to a safer and more stable banking system."); R. BRYANT, supra note 100, at 141 ("The supply of international regulatory cooperation is likely to fall short of what would be mutually beneficial because each nation, acting rationally on an individual basis, ignores the potential benefits of the greater cooperation for others."); B. CoHeN, supra note 100, at 303 (explaining that in the 1960's and 1970's governments "became engaged in a kind of 'competition in laxity' in the hope of avoiding any competitive disadvantages for their national banking systems"); Shirreff, The Fearsome Growth of Swaps, Euromoney, Oct. 1985, at 247, 253 (quoting Charles Lucas of the Federal Reserve Bank of New York as stating that central banks must harmonize their regulation of swaps, for "[o]therwise the busness will simply be driven to the least regulated markets"); of. Romano, The State Competition Debate in Corporate Law, 8 Cardozo L. Rev. 709 (1987) (article discussing competitive behavior on the part of the states with regard to incorporation laws).

103 See Kapstein, Resolving the Regulator's Dilemma: International Coordination of Banking Regulations, 43 INT'L ORG. 323, 328-29 (1989). 
sory Practices, or the "Cooke Committee," has centerposted international supervision of banks ever since. ${ }^{104}$

The Cooke Committee, United States bank regulators, and the Bank of England created, through a series of interdependent actions, an irresistible momentum toward the international coordination of bank safety and soundness through a capital adequacy approach. In June 1982 the Cooke Committee presented a paper which argued that "in the current and prospective environment further erosion of capital ratios should, on prudential grounds, be resisted; and that, in the absence of common standards of capital adequacy, supervisors should not allow the capital resources of their major banks to deteriorate from their present levels, whatever those levels may be."105 The Cooke Committee continued its work on capital adequacy amidst calls from regulators from around the world for strengthening the capital base of banks. ${ }^{106}$

104 Peter Cooke, an Associate Director of the Bank of England, was chairman of this Committee from 1977 to 1988. See Bank of England, ANnual Report Under THE BANKING ACT FOR 1988/89, at 20 (1989) [hereinafter 1989 BANK of ENGLAND ANNUAL REPORT]; see also R. BRYANT, supra note 100, at 145 (stating that the Cooke Committee is "[t]he most important forum for catalysing consultations and cooperation among banking supervisory authorities"); Norton, Capital Adequacy Standards: A Legitimate Regulatory Concern for Prudential Supervision of Banking Activities?, 49 OHг ST. L.J. 1299, 1339 (1989) (calling the Committee a "centrifugal force for creating a worldwide network for the exchange of information and the discussion of issues regarding bank prudential supervision").

The Cooke Committee represented a significant break with prior international practice. See, e.g., R. BRYANT, supra note 100, at 145 (explaining that before the formation of the Committee, "consultations among [national banking] authorities were infrequent and primarily bilateral"); B. CoHEN, supra note 100, at 303 (suggesting that the formation of the Cooke Committee marked a shift in international attitudes towards bank regulation); Duffy, Regulators Assess Group of 10 from Humble Start to Global Plan, AM. BANKER, July 27, 1988, at 1 (reporting Peter Cooke's belief that at the first meeting of the Committee, none of the banking supervisors from the Group of Ten industrial countries had ever met each other).

For a description of the purposes of the Committee, see Cooke, The Basle "Concordant" on the Supervision of Banks' Foreign Establishments, 39 AussenwIRTSCHAFT 151, 151 (1984) (stating the main purpose "is to work towards cohesion of arrangements for supervising the activities of banks operating in international markets .....").

105 Norton, supra note 104 at $1339-40$ (quoting CommitteE on Banking Regulations and Supervisory Practices, Report on INTERnational DeVElopments in Banking Supervision 1982, at 3 (1983)).

106 See, e.g., Lamfalussy, Is Change Our Ally?, Banker, Sept. 1986, at 24 (quoting the general manager of the Bank for International Settlements as referring to the need to "radically strengthen ... the capital base of all financial intermediaries and of banks in particular"); Norton, The Work of the Basle Supervisors Committee on Bank Capital Adequacy and the July 1988 Report on "International Convergence of Capital Measurement and Capital Standards," INT'L Law., Spring 1989, at 245, 253-54. 
At around the same time, Congress and the federal banking agencies had also become concerned with declining levels of capital in relation to assets. The International Lending Supervision Act of $1983^{107}$ called on the Chairman of the Federal Reserve Board and the Secretary of the Treasury to work with other countries to strengthen the capital adequacy of banks involved in international lending and required the federal banking regulators to establish minimum levels of capital domestically. ${ }^{108}$ The federal banking regulators responded with a series of capital adequacy rules. ${ }^{109}$ Unfortunately, these capital rules were not very specific on how they might be adjusted for the risk profile of individual banks. ${ }^{110}$ Countries such as France, Britain, and West Germany had more sophisticated capital adequacy approaches. ${ }^{111}$ In 1986, federal regulators proposed a revised system which explicitly took into account the riskiness of bank assets. ${ }^{112}$

The international collective goods issue raised its head and came to dominate the capital adequacy efforts. Many of the banks which commented on the proposal argued that, without similarly stringent risk-based capital standards in other countries, United States banks would be at a competitive disadvantage. Coincidentally, the Bank of England was also in the process of revising its capital adequacy system, a system that was conceptually similar to the United States proposal. The answer was at hand. In the fall of 1986, United States authorities deferred action on their own proposal to work with the Bank of England toward a common approach. On Jan-

10712 U.S.C. $\$ 3901$ (Supp. V 1987).

108 See id. at $\S 3907$. For a discussion of the pre-existing capital adequacy guidelines, see Note, International Banking: United States - United Kingdom Capital Adequacy Agreement, 28 HARv. INT'L L.J. 499, 501 n.2 (1987).

109 See 50 Fed. Reg. 16,057 (1985) (rules of the Federal Reserve Board); 50 Fed. Reg. 11,128 (1985) (rules of the Federal Deposit Insurance Corporation); 50 Fed. Reg. 10,207 (1985) (rules of the Office of the Comptroller of the Currency); see also Norton, supra note 104 , at 1327.

110 See Norton, supra note 104, at 1331 (noting that the capital adequacy rules "explicitly indicate that the regulators ... should factor into their capital analysis an assessment of institutional risks on a case-by-case basis").

111 See Bardos, The Risk-based Capital Agreement: A Further Step Towards Policy Convergence, Fed. Reserve Bank New York Q. Rev., Winter 1987-88, at 26, 27. The discussion in the text as to the historical background of the BIS Accord relies heavily on Bardos, supra.

112 See Comptroller of the Currency, Minimum Capital Ratios; Risk-Based Capital Standards for National Banks, 5 I Fed. Reg. 10,602 (1986); Federal Deposit Insurance Corporation, Capital Maintenance; Supplemental Adjusted Capital Proposal, 51 Fed. Reg. 6,126 (1986); Federal Reserve System, Bank Holding Companies and Change in Bank Control; Capital Maintenance; Supplemental Adjusted Capital Measure, 51 Fed. Reg. 3,976 (1986). 
uary 8,1987 , United States bank regulatory authorities and the Bank of England announced that they had agreed to request public comment on a proposed risk-based capital framework for banks and bank holding companies that had been jointly developed by federal bank regulators and the Bank of England. ${ }^{13}$ Regulators in the United States and the United Kingdom were aware that simply achieving a "level playing field" between the two countries would not do. There was concern that this effort to strengthen the regulatory framework in the United States and the United Kingdom would undermine the international competitiveness of banks from those countries. ${ }^{14}$ The regulatory authorities in the other major financial countries were forced to consider these concerns when United States and United Kingdom regulators deferred action on the joint proposal in order to seek the agreement of a larger number of countries. ${ }^{115}$ This joint U.S.-U.K. proposal also added pressure to the Cooke Committee

113 See Comptroller of the Currency, Federal Deposit Insurance Corporation, and Federal Reserve Board, Joint News Release, reprinted in INTEREST RATE AND Currency Swaps 1987, supra note 57, at 207. This agreement led to, among other things, Federal Reserve Board revision of its 1986 proposal. See Federal Reserve System, Capital Maintenance; Revision to Capital Adequacy Guidelines, 52 Fed. Reg. 5,119 (1987); Norton, supra note 106, at 258; $c$. Comptroller of the Currency, Minimum Capital Ratios; Issuance of Directives, 52 Fed. Reg. 23,045 (1987); Federal Deposit Insurance Corporation, Capital Maintenance; Risk-Based Capital Proposal, 52 Fed. Reg. 11,476 (1987).

114 See 1987 BBA Memorandum, supra note 68 , at 1 ("There is . . . a real danger that a strengthening of the regulatory framework in the U.K. and U.S. may undermine the competitive position of banks in those countries unless the supervisory authorities in other major countries introduce comparable arrangements."); Letter from Patrick de Saint-Aignan, Chairman, International Swap Dealers Association, Inc., to Brian Quinn, Head of Banking Supervision, Bank of England and William W. Wiles, Secretary, Board of Governors of the Federal Reserve System, at 10 (May 28, 1987) [hereinafter 1987 ISDA Letter] ("Any distortion of costs and pricing caused by an uneven regulatory playing field will have an immediate effect on competition"), reprinted in The 1987 London Swaps SEMINaR, supra note 26; see also Matthews \& Naylor, US Banks Seek Equal Treatment as Capital Talks Move to Japan, AM. BANKer, Jan. 12, 1987, at 1 (stating that at the time of the promulgation of the United States-United Kingdom proposal, the president of Federal Reserve Bank of New York was "reportedly discussing capital adequacy ratios with central banking officials in Japan, whose major banks have long operated with lower capital levels than those of many of their international competitors"); Regulating Swaps: Capital Punishment, Economist, May 30, 1987, at 78-79 ("British and American bankers fear that while they have to raise costly capital to meet the new rules, French, West German and Japanese Banks may carry on under their old rules.").

115 See Comptroller of the Currency, Federal Deposit Insurance Corporation, and Federal Reserve Board, Joint News Release (Dec. 10, 1987) [hereinafter December 1987 Joint News Release]. 
process. ${ }^{116}$ In April 1987, the Cooke Committee took the joint U.S.U.K. proposal under consideration and addressed the possibility of expanding the agreement to include all the countries represented on the Committee. ${ }^{117}$ In December 1987, the Cooke Committee set forth the conclusions of its discussions in the form of a proposal which broadly paralleled the U.S./U.K. proposal. ${ }^{118}$ In March 1988, the federal banking agencies issued for public comment a revised capital adequacy scheme based on the Cooke Committee proposal. In July 1988, following additional changes, the members of the Cooke Committee set out an agreed framework for measuring capital adequacy and a minimum capital standard which the members would implement in their respective countries. This framework was subsequently endorsed by the central bank Governors of the Group of Ten. ${ }^{119}$ In the United States, implementing regulations in turn were adopted by each of the primary federal banking regulators for their respective commercial bank and bank holding company charges. ${ }^{120}$

116 See Norton, supra note 106 , at 258.

117 See Bardos, supra note 111 , at 28.

118 See Committee on Banking Regulations and Supervisory Practices, Bank for International Settlements, Proposals for International Convergence of Capital Measurement and Capital Standards (Dec. 1987); December 1987 Joint News Release, supra note 115 . The proposals, however, did incorporate certain changes in the methodology dealing with swaps and related products. For instance, the proposals provided that no capital was required to cover the potential credit exposure on single currency floating/floating interest rate swaps; the credit exposure on these contracts would be evaluated solely on the basis of their mark-to-market value (that is, the current exposure). See id. annex 3, at 4.

119 See Banking Supervision Division, Bank of England, Implementation of the Basel Convergence Agreement in the United Kingdom 1 (1988) [hereinafter BOE Caprtal Guidelines]; Norton, supra note 106, at 262.

120 See supra note 31 . Federal bank regulators plan on supplementing the riskbased capital adequacy system contemplated by the BIS Accord with modified versions of the pre-existing non-risk-based capital adequacy rules. If a bank were subject only to the risk-based capital adequacy requirements, the bank would be able to operate with very low absolute levels of capital if its assets were subject to zero or low capital requirements (such as government securities). A supplemental, non-riskbased capital adequacy system based on minimum capital to total asset ratios could prevent this from occurring. Matters pertaining to this supplemental capital adequacy system have been highly controversial and, as of the beginning of November 1989, not fully resolved. See FDIC Capital Guidelines, supra note 31, at 11,508; FRB Capital Guidelines, supra note 31, at 4,193; OCC Capital Guidelines, supra note 31, at 4,171; Minimum Capital Ratio, 54 Fed. Reg. 46,394 (1989) [hereinafter OCC Supplemental Capital Requirement Proposal] (notice of proposed rulemaking as to existing Office of the Comptroller of the Currency capital-to-totalasset ratios); OCC Proposes Minimum Leverage Ratio; Capital Standards Debated, 28 Control BANking $\$ 6.4$ (Sept. 15, 1989) (describing OCC proposal of a $3 \%$ minimum capital-to-total assets ratio to supplement the current risk-based guidelines); see also infra note 133 (concerning Office of the Comptroller of the 
This broadly based international regulatory movement subsumed concerns about swaps and related hedging products. Swaps proved particularly troublesome to the regulators because of the complexity of evaluating their credit risk. One Bank of England regulator asserted that regulators "had a more thorough and longer running debate with the swaps market on the sort of capital requirements to apply to them than [they] have had with almost any other sector of the banking market."121 Although it was clear that swaps exposed banks to credit risk, by late 1985 United States bank regulators had not yet developed a practical way of incorporating a measure of this risk in a risk-based capital framework. ${ }^{122}$ Initial international regulatory efforts were limited mostly to gathering information on reporting mechanisms and on the extent to which banks were involved in financial innovation activities. Banks were also called upon to strengthen training programs and monitoring with respect to the risks associated with these activities. ${ }^{123}$ More sophisticated analyses followed. ${ }^{124}$ In the course of the work prior to

Currency's interest rate risk argument for supplemental capital adequacy system); $c f$. Regulatory Capital, 54 Fed. Reg. 46,845 (1989) (interim final rule adopted by the Office of Thrift Supervision as to minimum regulatory capital regulations for savings and loan associations).

The European Community has engaged in parallel efforts to harmonize "solvency" ratios among the twelve member states. See 1989 BanK of ENGLand ANNUAL REPORT, supra note 104, at 21-23; Clearing up the Confusion (or muddying the waters?), EuRomaRkET ReP., Apr. 24, 1989 (available on LEXIS); EC Ministers Agree on Capital Adequacy Definition, In Move Toward Harmonization, 51 Banking Rep. (BNA) 1041 (1988); Second Banking Directive Agreed, INT'L Banking REP., July 1989 (available on LEXIS) [hereinafter EC Efforts]; European Community Council, Common Position Adopted by the Council on 24 VII 1989 with a View to the Adoption of the Directive on a Solvency Ratio for Credit Institutions [hereinafter EC Council Common Position].

121 The 1987 London Swaps Seminar, supra note 26, at 92 (remarks of Carol Sergeant, Banking Supervision Division, Bank of England); see also Mayer, The Currency Options Snafu, Am. BANker, Aug. 4, 1988, at 1 ("The recent Basel agreement of the central banks to set new capital requirements for their wards grows mostly from the regulators' concern about the risks involved in these swaps and options."):

122 See Bardos, supra note 111 , at 33.

123 See Cooke, Co-operation Between Regulatory Authorities, in New Financial INSTRUMENTS: DisclosuRE AND ACCOUNTING 205-206 (Organisation for Economic Co-operation and Development ed. 1988); see also Banking Supervision Division, Bank of England, Off Balance Sheet Business of Banks: Consultative Paper by THE Bank of England (Mar. 1986) [hereinafter 1986 Consultative Papers] ("The Bank is keenly aware that it does not currently receive statistics on many types of offbalance sheet business except on an ad hoc basis."), reprinted in INTEREST RATE AND Currency Swaps 1987, supra note 57, at 400.

124 See, e.g., 1986 Consultative PAPER, supra note 123, at 385-86 (preliminary report on off-balance sheet risk prepared by the Basel Supervisor's Committee); Cross RePort, supra note 3, at 37-60 (report of study group established by the central banks of the Group of Ten countries on new financial instruments). 
the January 1987 United States-United Kingdom announcement, a special task force comprised of representatives of the Bank of England, the Federal Reserve Board, and the Office of the Comptroller of the Currency was established to develop a measure of credit risk acceptable to both countries. ${ }^{125}$ Even then, the task force could not agree on an appropriate measure of swap risk by the time of the United States-United Kingdom proposal. ${ }^{126}$ The American and British regulators did proclaim that it was their "firm intention" to include the "credit equivalent exposure on interest rate and foreign exchange rate related transactions in the risk asset ratio as soon as possible." 127

On March 7, 1987, the Federal Reserve Board and the Bank of England published an agreed proposal on the measurement of credit risk on swaps and other related instruments. ${ }^{128}$ Subsequently, regulators from a much wider group of countries ${ }^{129}$ joined in the swap discussions; the center of discussion moved to the Cooke Committee. ${ }^{130}$ During multilateral discussions on this proposal, several members of the Cooke Committee objected to the United StatesUnited Kingdom approach. There was a compromise: in both the December 1987 Cooke Committee proposals and the BIS Accord, two alternative ways of calculating swap credit risk were adopted, one simple and one complex. The International Swap Dealers Association and individual banks were active throughout the process. ${ }^{131}$

These three factors - the international collective action problem, the underlying movement to use capital adequacy to ensure the safety and soundness of banks, and the specific capital adequacy actions pertaining to swaps and related products - led to the definition of the swaps "problem" primarily in terms of credit risk. Under the BIS Accord then, banks were to have capital sufficient to absorb losses that might arise in connection with defaults by their customers

125 See Bardos, supra note 111 , at 27.

126 See id. at 27-28.

127 Agreed Proposal of the United States Federal Banking Supervisory Authorities and the Bank of England on Primary Capital and Capital Adequacy Assessment, reprinted in INTERest Rate and CURRenCy Swaps 1987, supra note 57, at 278 (citations omitted).

128 See FRB/BOE Credit Exposure Memorandum, supra note 57, at 325; see also Staff Memorandum, Treatment of Interest Rate and Exchange Rate Contracts in the Risk Asset Ratio (Mar. 3, I987), reprinted in Interest Rate and Currency Swaps 1987, supra note 57, at 289 (describing the proposal).

129 See The 1987 London Swaps Seminar, supra note 26, at 93 (statement of Carol Sergeant, Bank of England).

130 See id.

131 See, e.g., supra note 36 (concerning comment letters). 
on their swaps and related products. ${ }^{132}$ Other kinds of risks, such as the interest rate risk which might arise from not finding perfectly matched counterparties, basically were left for another day. ${ }^{133}$

\section{The BIS Accord: Theory and Operation}

\section{a. Conceptual Underpinnings of the Capital Adequacy Approach}

Thus far, we have seen how the regulators embraced a riskbased capital adequacy approach as a way of enhancing the soundness of the international banking system. In order to evaluate the capital adequacy system established by the BIS Accord, we need to understand in greater detail how increasing the amount of capital is supposed to increase bank safety. We must also examine why it is important from society's point of view that the amount of capital required be set at appropriate levels. We turn now to these two issues.

Those who believe that capital adequacy requirements can enhance bank safety ${ }^{134}$ typically rely on three related grounds. ${ }^{135}$

132 See BIS ACCORD, supra note 2, Annex 3, at 2.

133 See id. at 3; cf. OCC Supplemental Capital Requirement Proposal, supra note 120 (Office of the Comptroller of the Currency noting that one of the reasons for a capital adequacy system supplemental to that contemplated by the BIS Accord is the need to take interest rate risk into account); Regulatory Capital, 54 Fed. Reg. 46,845 (1989) (the Office of Thrift Supervision stating in November 1989 that it anticipated publishing in "the near future" a notice of proposed rule-making dealing with interest-rate risk faced by savings and loan associations); Adequacy of Examination Levels and Compensation: Hearing Before the Subcomm. on Financial Institutions Supervision, Regulation and Insurance of the House Comm. on Banking, Finance and Urban Affairs, 101st Cong., 1st Sess. 169 \& 214-19 (1989) [hereinafter Banking Supervision Hearings] (regulatory analysis of the interest rate risk of savings and loan associations); supra note 43 (concerning asset-liability management policies); supra note 16 (describing interest rate risk generally); supra note 59 (describing interest rate risk which can arise in swap context from imperfectly matched swaps).

134 Although the world-wide movement to the capital adequacy approach would suggest otherwise, the usefulness of the usual accounting-based capital adequacy approach in assuring the safety and soundness of banks has been the subject of fierce theoretical debate and is not settled. Analysis of the deficiencies of the capital adequacy approach, other than as the approach relates directly to the financial innovation process, is beyond the scope of this Article. For some illustrative critiques of capital adequacy as a regulatory tool, see G. BENSTON \& G. KaUFMAN, supra note 91, at 38-42 \& 47-53; Clark, supra note 90, at 63-64 ("[T] capital measure continues, apparently in the belief that capital cushions must have something to do with bank soundness."); Gilbert, Stone \& Trebing, The New Bank Capital Adequacy Standards, Rev. Federal Reserve Bank St. Louis, May 1985, at 12 \& $\mathrm{n.5}$ ("There is remarkably little evidence ... that links the level of capital or the ratio of capital to assets with bank failure rates."); Koehn \& Santomero, Regulation of Bank Capilal and Portfolio Risk, 35 J. FIN. 1235, 1244 (1980) ("[A] case could be argued that 
The first ground is based on accounting notions. Under accounting conventions, losses suffered by a bank are first deducted from the bank's capital account. Thus, the argument goes, during lean times capital can serve as a cushion to absorb losses and ward off insolvency. ${ }^{136}$ Increases in the size of the cushion would reduce the chances of balance sheet insolvency. Moreover, to the extent that people believe that the amount of bank capital is correlated with bank safety, a high capital standard will help foster confidence in the bank; a perception of stability has independent value. ${ }^{137}$

The second ground is based less on such balance sheet notions and more on the ability of a bank with low levels of capital to meet its debt and other obligations on a continuing basis. Generally speaking, to the extent that a bank relies on outside funding to finance bank operations, a bank can do so either by obtaining capital (such as by issuing shares of common stock) or by incurring liabilities (such as by issuing bonds or obtaining additional deposits). Shareholders are not entitled to fixed payments from the bank while bondholders and

the opposite result can be expected to that which is desired when higher capital requirements are imposed.").

135 According to the United States General Accounting Office:

Greater capital levels will help institutions absorb losses, since capital provides a buffer to protect depositors and the funds from decreases in the value of assets or earnings declines. If the increased capital is raised in the public markets, it should provide more impetus for market discipline as more outsiders have a financial stake in the performance of depositary institutions. As a result of this discipline, riskier institutions may find it harder to grow as rapidly. An additional advantage associated with capital is that it is far less destabilizing to rely on investors, shareholders, or other long-term creditors to bear risk and impose market discipline on bank and thrift behavior than to rely on the more volatile uninsured short-term depositors.

1 U.S. General Accounting Office, Deposit Insurance: Analysis of Reform Proposals 102 (1986) (quoting January 1985 Cabinet Council Recommendations for Change in the Federal Deposit Insurance System); see also Y. Orgler \& B. WolkowITZ, BANK CAPITAL 14-18 (1976); Wall, supra note 91, at 8-12 (noting that "[i]ncreased capital can protect banks from insolvency by providing a cushion to absorb losses"); $c f$. Crouhy \& Galai, An Economic Assessment of Capital Requirements in the Banking Industry, $10 \mathrm{~J}$. BANKING \& FIN. 231 (1986) (describing four different roles attributed to bank capital by those who believe in capital adequacy approach); Mingo, Capital Ratios: The Reg Q Fiasco of the Fulure?, 4 Banking Expansion Rep. (CCH) 8, 9 (Jan. 21, 1985) (describing the three major purposes capital serves according to regulators).

136 See G. Benston \& G. KAufman, supra note 91, at 38; Wall, supra note 91, at 4; cf. Gilbert, Stone \& Trebing, supra note 134, at 13 (noting difference between "accounting" definition of capital and "economic" definition of capital).

137 Cf. Wall, supra note 91 , at 38 (noting that equity capital "protects against illiquidity resulting from deposit runs" and is a factor in "helping to maintain depositor confidence"). 
depositors are entitled to their principal and interest regardless of economic conditions. The familiar result is that, everything else held equal, the larger the amount of funding by way of capital, the more likely the bank will be able to meet its obligations to the liability holders. ${ }^{138}$ While the government does not usually interfere with a private firm's decision on how much capital it ought to have, there are externalities and moral hazard problems which affect bank decisions in this area. The failure to take into account the effects of its failure on society and the reliance on the governmental safety net cause bank management to elect to have too little capital from the standpoint of society as a whole. ${ }^{139}$

The third ground is based on the notion of subjecting management to the financial discipline of the market for equity capital. If a bank wishes to grow it may first have to meet the market test of being able to obtain new capital. Capital adequacy requirements may thus have the effect of helping curb bank expansion. ${ }^{140}$

In order for capital adequacy requirements to operate as intended, those requirements must be set at the right levels. If the capital adequacy requirement of a particular activity is set too low, it is unlikely to contribute to the safety and soundness of the financial system. If, for instance, the mandated capital requirement were equal to or lower than the amount of capital the bank itself would have selected, a capital adequacy requirement would have no effect at all. Indeed, there may be a perverse effect: to the extent that financial institutions view the legally established capital requirements as officially sanctioned estimates of riskiness, the underestimation of risk for regulatory purposes will seep into commercial bank decisions. ${ }^{141}$

138 Cf. W. Klein \& J. Coffee, JR., Business Organization and Finance: Legal and Economic Principles 285-86 (3d ed. 1988) (explaining effects of leverage); Furlong \& Keeley, Bank Capital Regulation and Asset Risk, EcoN. REv., Spring 1987, at 20, 22 (describing effect of greater amounts on capital on likelihood of bank meeting obligations to its liability holders).

139 See Shome, Smith \& Heggested, Do Banks Have Adequate Capital?, Bankers MAG., July-Aug. 1989, at 21; Wall, supra note 91, at 5-7; supra notes 91-99 and accompanying text.

140 But see G. Benston, R. Eisenbeis, P. Horvitz, E. Kane \& G. Kaufman, Perspectives on Safe \& Sound Banking: Past, Present, and Future 175-76 (1986) (arguing that evidence provides "only tenuous support for the view that stockholders are a significant force for conservative operation"); Litan, supra note 63, at 35-36 (noting that shareholders are ineffective monitors of bank risk-taking because they are likely to be willing to take more risks than federal insurance agencies).

141 See BIS AcCORD, supra note 2, at 10 ("[T] regarded as a substitute for commercial judgement for purposes of market pricing of the different instruments."); The 1987 London Swaps SEminar, supra note 26, at 99- 
There are also serious consequences for setting too high a capital standard, all of which substantially derive from the costs imposed by such a standard. A bank, like any other enterprise, seeks to operate with a capital structure that is optimal from its own point of view, a structure that maximizes its value. While the capital structure of a firm will not affect its value in a world of highly restrictive economic assumptions, ${ }^{142}$ in the real world of taxes and other imperfections, theorists postulate that an optimal capital structure does exist (even if it is difficult to determine). ${ }^{143}$ To the extent that regulation forces a deviation from the optimal capital structure, opportunity costs are imposed on the bank shareholders. ${ }^{144}$

From a public policy viewpoint, there can be two effects of an overly restrictive capital adequacy requirement. First, to the extent that capital requirements are too high as to a particular activity, banks will not engage in a socially optimal amount of that activity. The profit margins on swaps are extremely thin; even slight increases in the capital requirements would unnecessarily increase prices or

100 (statement of David Gelber, Chemical Bank International); $c f$. infra notes 145 and 264.

142 See Modigliani \& Miller, The Cost of Capital, Corporation Finance and the Theory of Investment, 48 AM. EcoN. REv. 261, 261-63 (1958). For additional discussions, see R. BREALEy \& S. Myers, supra note 16, at 383-402; Black, Miller \& Posner, An Approach to the Regulation of Bank Holding Companies, 51 J. Bus. 379 (1978).

143 See R. Brealey \& S. Myers, supra note 16, at 437 (arguing that "[t]here is no neat formula that you can plug in to find the optimal capital structure" but that one should consider such factors as taxes and risk); Jensen \& Warner, The Distribution of Power Among Corporate Managers, Shareholders, and Directors, 20 J. Fin. ECoN. 3, 5 (1988); Stillit, The Perfect Capital Siructure: Does it Exist?, CoRP. FIN., Nov. 1988, at 54.

144 See Stillit, supra note 143 , at 54. 
decrease availability. ${ }^{145}$ Financial innovation would also be unnecessarily dampened. ${ }^{146}$

Second, there is a danger of misallocations in the economy arising from too much equity and not enough debt in the capital structure of banks. ${ }^{147}$ A capital adequacy standard that is too high from the social point of view would unnecessarily increase the cost of funds for the banking industry. The overall efficiency of the financial system would be affected. ${ }^{148}$

145 The regulatory "price" with respect to amount of capital required can affect the price actually charged by banks for their swaps. See, e.g., Capital Adequacy: Japanese feel the pinch, INT'L FIN. REv., Apr. 23, 1988, at 1339 (discussing effect of capital adequacy requirements on willingness of Japanese banks to enter into currency swaps); Cooper, Still Plenty of Room to Grow, Euromoney, Oct. 1988, at 35, 36 (discussing in-house analysis by Shearson Lehman Hutton on effect of rules on the spreads for currency swaps and interest rate swaps); Donaldson, The G10 capital adequacy requirements, BANkING WorLD, Aug. 1988, at 42, 43 (Morgan Guaranty officer asserting that new capital requirements constitute a cost which will be reflected in price of swaps); Levis \& Suchar, What Those Guidelines Mean, Euromoney, Sept. 1989, at 215 (analyzing effect of the BIS Accord's capital requirements on the market for currency swaps and interest rate swaps); What price capital adequacy?, CoRP. Fin., Jan. 1989, at 13-14 (indicating in a table the impact of different capital adequacy requirements on required "spread"); id. at 13 (noting that some banks have already stopped making markets in currency swaps as a result of increased capital adequacy requirements); Letter re: Interest Rate and Exchange Rate Contracts from Kenneth N. LaVine, Jr., Chief Financial Officer, Chemical Bank to William W. Wiles, Board of Governors of the Federal Reserve System, at app. (May 27, 1987) (attachment to letter illustrating the pricing implications of capital adequacy requirements); $f$. Staff Memorandum, supra note 128, at 10-11 (expressing concern over impact of capital adequacy requirements on swap pricing). But see Cooper, supra, at 35 (stating that most commercial banks would swallow a lower rate of return on swaps rather than raising prices and losing business to the investment banks not subject to such capital adequacy rules).

146 Evaluating the social benefits and costs of a new financial product is extremely difficult. The literature on the evaluation of the social benefits and costs of product innovations generally is only now emerging. See Trajtenberg, The Welfare Analysis of Product Innovations, with an Application to Computer Tomography Scanners, $97 \mathrm{~J}$. POL. Econ. 444, 445 (1989) (stating that the "literature on product innovations is very scanty"). The absence of a fully accepted explanation of why swaps even exist would hinder a completely convincing analysis of the social benefits and costs of swaps. For some illustrative analyses as to the social value of financial innovations, see Impact of the Stock Market Drop and Related Economic Developments on Interest Rates, Banking, Monetary Policy and Economic Stability: Hearing Before the House Comm. on Banking, Finance and Urban Affairs, 100th Cong., 1st Sess. 18 (1987) (statement of Professor John Kenneth Galbraith); Cross REPORT, supra note 3, at 187-254; Brown \& Smith, Recent Innovations in Interest Rate Risk Management and the Reintermediation of Commercial Banking, Fin. MGMT., Winter 1988, at 45, 56-57; Keeley, Financial Innovation and Social Benefit, in Finance and the International Economy: The AMEX Bank Review Prize Essaxs 117-35 (J. Calverley \& R. O'Brien eds. 1987).

147 See Stillit, supra note 143 , at 54.

148 See Wall, supra note 91, at 12. Moreover, such a deterioration in the competitive position of banks may mean that "banks will forgo some share of the 


\section{b. The BIS Accord's Operative Provisions}

The BIS Accord is designed to result in minimum levels of capital for internationally active banks. ${ }^{149}$ These capital adequacy ratios are being phased in, with interim figures and stringent final requirements which must be met by the end of 1992. National authorities are permitted to set ratios which are higher than the minimums prescribed in the BIS Accord, but may not set lower ratios.

The ratios are meant to ensure that each bank has a ratio of "capital" to "aggregate credit risk" which is no less than that specified by the BIS Accord. Thus, if a bank makes more loans, its aggregate credit risk (that is, the denominator) would increase. If the bank had been operating with the minimum permissible amount of capital, it would have to increase the amount of capital (that is, the numerator) in order to remain in compliance. The amount of capital and the

market for various financial services" and thus "the government's ability to protect the money supply could be undermined." Id. at 12-13. For a fuller exposition of the costs imposed both on banks and on society as a whole by a forced overcapitalization of banks, see Santomero \& Watson, Determining an Optimal Capilal Standard for the Banking Industry, 32 J. Fin. 1267, 1272-77 (1977).

149 See BIS AcCORD, supra note 2, at 3. In the United States, federal bank regulators elected to apply the BIS Accord system to all commercial banks instead of restricting its application only to internationally active banks and decided to retain a supplementary, non-risk based capital adequacy system. The regulations pertain as well to bank holding companies. See supra notes 31 and 120.

The BIS Accord stated that its fundamental objectives were "firstly, that the new framework should serve to strengthen the soundness and stability of the international banking system; and secondly that the framework should be fair and have a high degree of consistency in its application to banks in different countries with a view to diminishing an existing source of competitive inequality among international banks." BIS ACCORD, supra note 2, at 2.

The capital adequacy rules spawned by the BIS Accord do not apply to investment banks in the United States. Indeed, the Securities and Exchange Commission's efforts to ensure the capital adequacy of investment banks with respect to swap exposure have been narrow in scope and have lagged behind those of the commercial bank regulators. See Swaps Players on the Sidelines, INT'L. FIN. Rev., Mar. 14, 1987 , at 913,915 ; supra note 30 . Nevertheless, the number and thoughtfulness of the comment letters filed by investment banks in connection with the proposals which ultimately led to the BIS Accord indicate that investment banks believe those commercial bank rules will ultimately affect them in some way as well. Cf. Swap Players on the Sidelines, supra (describing how investment banks do not want to be seen as inadequately capitalized by the Federal Reserve Board); $f f$. IOSC Technical Report, supra note 30 , at $3 \mathrm{n} .3$ (noting possibility of securities firms dealing in swaps through unregulated affiliates). For current and proposed Securities and Exchange Commission net capital rules, see Securities and Exchange Commission, Net Capital Requirements for Brokers or Dealers, 17 C.F.R. § 240.15c3-1 (1989); Net Capital Rule, Exchange Act Release No. 27,249, 52 Fed. Reg. 38,322 (1989); see also Haberman, Capital Requirements of Commercial and Investment Banks: Contrasts in Regulation, Fed. Reserve Bank New York Q. Rev., Autumn 1987, at 1. 
amount of credit risk a bank is considered to have must be calculated in the manner prescribed by the BIS Accord.

In calculating what constitutes "capital" for the purposes of the ratios, the BIS Accord emphasizes equity capital and disclosed published reserves from post-tax retained earnings. This "Tier l," or core capital, is considered to be the only element common to all countries' banking systems, wholly visible in the published accounts. Other forms of capital - such as unpublished reserves, loan loss reserves and certain subordinated debt - may count towards the capital requirement, but only to a limited extent.

The denominator is intended to reflect the credit exposure of the bank. Roughly speaking, the most a bank can lose on a traditional loan is the principal amount. Consistent with this, under the BIS Accord, for most bank loans the credit exposure figure associated with a traditional loan is simply the amount of the loan. However, because borrowers vary in creditworthiness, loans of equal principal amounts in fact can differ in riskiness. The BIS Accord recognizes this in a broad brush way.

For a typical loan to a corporation, the full amount of the loan will be used for the denominator; in other words the "risk weight" is one hundred percent. With a loan in local currency to a central government of the Organization for Economic Cooperation and Development (the "OECD"), on the other hand, there is presumed to be no credit risk; in other words the "risk weight" is zero percent and no capital need be held against these sorts of loans. There are also intermediate points. For example, assets consisting of claims on banks incorporated in the OECD are assigned a risk weight of $20 \%$ while claims on banks incorporated outside the OECD with a residual maturity of over one year are given a risk weight of one hundred percent. Because of the disparity in weights, a $\$ 5$ million loan to an OECD bank will generally trigger a capital requirement equal in amount to a $\$ 1$ million long-term loan to a non-OECD bank.

Swaps and related products had to be treated differently from loans. As discussed previously, ${ }^{150}$ the amount of credit exposure a bank has on a swap, unlike the credit exposure the bank has on a loan, constantly fluctuates in size with hour to hour movements in interest rates and exchange rates. Moreover, the notional amount of a swap is merely one of many factors to be taken into account in calculating credit exposure; the principal amount of a loan, however, is in and of itself a fairly good measure of the maximum possible loss

150 See supra notes $64-72$ and accompanying text. 
on customer default. Recognizing this, the BIS Accord adopts for swaps and related products the notion of "credit equivalents." Swaps and related products are put through a two-step procedure: they are first converted into "credit equivalents" and then risk weights are applied to these credit equivalents.

Unfortunately, the regulators of the Group of Ten Countries could not agree on how to calculate credit equivalents. ${ }^{151}$ They adopted two alternative methods, both of which depend to some extent on a classification-based approach to assigning a capital price to individual swaps.

The "original exposure" method to determining credit equivalents 152 is the simpler of the two. This method does not rely at all on the mark-to-market values for current exposure or separate measures to reflect potential exposure as discussed earlier. ${ }^{153}$ Instead, this method simply assumes that the credit exposure is equal to the notional amount of the bank's swap multiplied by specified numbers (called "conversion factors"). Thus, a bank would merely apply one of the two sets of conversion factors indicated in Table 2 to the notional principal amounts of each instrument according to the nature of the instrument and its maturity. Once the credit equivalent is calculated, it is multiplied by the applicable risk weight. A swap dealer's swap with an OECD bank, for instance, would have its credit equivalent multiplied by twenty percent. However, because most regulators believed that customers of swap dealers were creditworthy, a maximum of weight of fifty percent is applied with respect to customers who would otherwise attract a one hundred percent weight. ${ }^{154}$

151 See Bardos, supra note 111, at 34; cf. EC Council Common Position, supra note 120 , at Annex II (discussing the "marking to market" approach and the "original exposure" approach).

152 See Intermational Regulation, in Inside the SwaP Market 95, 99 (3d ed. 1988).

153 See supra text accompanying notes $65 \& 66$.

154 The International Swap Dealers Association specifically lobbied for $50 \%$ weighting for this reason. See Letter from Mark C. Brickell, Chairman, International Swap Dealers Association, Inc., to William W. Wiles, Board of Governors of the Federal Reserve System, at 5 (May 13, 1988) [hereinafter 1988 ISDA Letter]; 1987 ISDA Letter, supra note 1 14, at 8-9. Until recently, the extent of defaults in the swaps area had been relatively limited. See Weiner, Survey Shows Losses Are Low in Swap Market, AM. BANKER, July 20, 1988, at 2.

Default statistics can change quickly as to new financial products. On November 1, 1989, Britain's High Court reportedly ruled that swaps entered into by Hammersmith \& Fulham (a local council in London) were ultra vires and unenforceable. As of the time of judgment, Hammersmith \& Fulham's swap portfolio totalled almost three billion pounds. An appeal is being brought by $\mathbf{3 5}$ banks involved in swap transactions with that local council. As of early November, 
Maturity

Less than one year

One year or more but less than two years

For each additional year
Interest Rate

Contracts

$0.5 \%$

$1.0 \%$

$1.0 \%$
Exchange Rate

Contracts

$2.0 \%$

$5.0 \%$

$3.0 \%$

Table 2

This original exposure approach to calculating credit equivalents will often generate numbers bearing only the most tenuous relationship to the true credit exposure on any individual swap. At the commencement of a typical swap, for instance, the actual credit exposure is almost negligible because the swap terms correspond to the prevailing market conditions; yet the original exposure approach assigns the same weight at commencement as at subsequent, "riskier" points in time. In addition, because interest rates and exchange rates will always be fluctuating, the mark-to-market value of the swap can vary considerably over the life of a swap. Because a swap dealer's true economic exposure on a swap at any given time depends on the mark-to-market value of the swap, the exposure will vary as well from time to time. By way of contrast, under this regulatory approach, movements in the actual mark-tomarket values of a given swap are totally ignored. As a result, only through happenstance will the figure calculated under this regulatory approach equal the true exposure faced by the dealer.

This original exposure approach thus cannot not be accurate as to any individual swap. The justification for this approach would have to be grounded on the notion that, viewing a bank's swap portfolio in the aggregate, the figures generated under this approach should provide estimates of credit risk which are accurate enough for regulatory purposes. Since currency swaps are generally riskier than interest rate swaps of the same notional amount and duration, higher capital requirements are imposed on currency swaps. Since the credit risks of swaps generally increase with notional amount and

industry sources reported that 20 local authorities had officially suspended swap transactions. See A Little Local Difficulty, Economist, Mar. 18, 1989, at 84; Britain's highcourt swap-shop, Economisr, Nov. 4, 1989, at 93; Dumping Britain's Local-Council Swaps, Economist, May 6, 1989, at 71; Evans, 35 Banks Prepare for Their Appeal in UK Swap Case, Am. Banker, Nov. 14, 1989, at 6; Swaps in the Town Hall, Bus. L. Brief, July 1989 , at 6; N.Y. Times, Nov. 6, 1989, at 25, col. 3. 
duration, the capital required increases as well. Simplicity is the chief virtue of this original exposure approach. ${ }^{155}$

The United States and the United Kingdom went down a different, more sophisticated path ${ }^{156}$ of calculating credit equivalents for swaps and related products. The United States and the United Kingdom divide these products into two broad categories: "interest rate contracts," like interest rate swaps and related interest rate hedging instruments, and "exchange rate contracts," like currency swaps and related currency hedging instruments. ${ }^{157}$ Although designated the "current exposure" method, this method in fact relies on measures both of current and potential exposures. ${ }^{158}$ The credit exposure is deemed to consist of both a "current exposure" element and a "potential exposure" element. Specifically, the regulators assumed, over the objections of some in the swaps industry, ${ }^{159}$ that the credit

155 There are a number of other problems associated with the original exposure method's approach to estimating the credit risk of swaps. See, e.g., Ferron \& Handjinicolaou, supra note 41 , at 145-46; 1988 ISDA Letter, supra note 154, at 4.

156 See BOE CAPITAL Guidelines, supra note 119, at 10; FDIC Capital Guidelines, supra note 31, at 11,515; FRB Capital Guidelines, supra note 31, at 4,205 \& 4,217; OCC Capital Guidelines, supra note 31 , at 4,182.

157 Under the Federal Reserve Board rules implementing the BIS Accord, applicable to banks and bank holding companies, the special rules applicable to swaps and related products are applicable as well to the following instruments:

I. Interest Rate Contracts

A. Single currency interest rate swaps.

B. Basis swaps.

C. Forward rate agreements.

D. Interest rate options purchased (including caps, collars, and floors purchased).

E. Any other instrument that gives rise to similar credit risks (including when-issued securities and forward deposits accepted).

II. Exchange Rate Contracts

A. Cross-currency interest rate swaps.

B. Forward foreign exchange contracts.

C. Currency options purchased.

D. Any other instrument that gives rise to similar credit risks.

See FRB Capital Guidelines, supra note 31 , at 4,205 \& 4,217; see also BOE CAPrTAL Guidelines, supra note 119, at 10 (Bank of England categorizations of "exchange rate contracts" and "interest rate contracts"); FDIC Capital Guidelines, supra note 31 , at 11,515 (Federal Deposit Insurance Corporation definitions of "foreign exchange rate related contracts" and "interest rate related contracts"); OCC Capital Guidelines, supra note 31 , at 4,178 (Office of the Comptroller definitions of "exchange rate contracts" and "interest rate contracts").

158 See supra text accompanying notes 63-65.

159 For some of these objections, see Ferron \& Handjinicolaou, supra note 41 , at 142-48; 1987 ISDA Letter, supra note 114, at 3-4.

This Article does not attempt to provide a full description of the true credit risks 
risk equals the sum of the "mark-to-market" valuation (representing current exposure) and an "add-on" (representing potential exposure). With the vast majority of swaps, a bank calculates the "credit equivalent amount" by adding:

(a) the total replacement cost (obtained by doing mark-tomarket valuations) ${ }^{160}$ of all of its contracts with positive value; and

(b) an amount (an "add-on") for potential future credit exposure calculated on the basis of the total notional principal amount of its book (including contracts with positive, zero, and negative value), split by residual maturity as follows:

Residual Maturity

Less than one year

One year and over
Interest Rate Contracts nil $0.5 \%$
Exchange Rate Contracts $1.0 \%$ $5.0 \%$

Table $3^{161}$

With the current exposure method, as with the original exposure method, once the "credit equivalent" amount of a swap is calcu-

of swaps, but instead abstracts some of the factors which help determine credit risk in the context of the financial innovation process. See supra note 57. Similarly, this Article does not provide an overall critique of the BIS Accord's evaluation of swap credit risk. The comment letters filed over the years in connection with the BIS Accord, its antecedents and the implementing regulations provide the best analysis with respect to these broader issues. See supra note 36 .

160 Neither the Bank of England nor United States banking authorities specifically mentioned how mark-to-market values would be calculated. It is the understanding of the British Bankers' Association that the Bank of England intended to have discussions with individual institutions to ensure consistency of approach, instead of simply publishing a formula. See British Bankers' Association, Memorandum to the Bank of England on the Bank's Explanatory Paper issued IN JANUARY, 1988, at 7 (Apr. 1988).

161 Certain products thought to involve less credit risk are excluded from this calculation, and as such either do not trigger capital requirements or trigger only less stringent capital requirements. These products include interest rate swaps in which the payments exchanged are based on floating rate indices; exchange rate contracts which have an original maturity of no more than fourteen days; and instruments subject to daily margining which are traded on exchanges. See, e.g., BIS Accord, supra note 2, annex 3, at 22; BOE CAPITAL. GuIDELINEs, supra note 119, at $10 \mathrm{nn} .1-2$.

The Bank of England and federal banking regulators adopted the precise percentages set forth in the BIS Accord rather than a higher percentage. This was not surprising given the natural desire of regulators not to handicap their own domestic financial institutions relative to those of other nations. See, e.g., BritisH Bankers' Association, Memorandum on the Consultative Paper issued by the Basle CommitTee in December 1987, at 2 (Apr. 1988) (stating that it "will be essential for national supervisory authorities to build on [the common system] in the same way"). 
lated, a risk weight is applied. In the United States and the United Kingdom, this risk weight will be fifty percent in the usual case. ${ }^{162}$

A simple example, using plain vanilla interest rate swaps, may be helpful. ${ }^{163}$ Assume that a swap dealer enters into two interest rate swaps with two of its regular corporate customers. Each swap has a term of three years and is in the notional amount of $\$ 10,000,000$. In a swap into which the bank enters with customer A on January 1, 1990 , the swap dealer is the floating rate payor and customer $A$ is the fixed rate payor. In a swap into which the bank enters with customer $B$ on July 15, 1990, the roles are reversed: the swap dealer is the fixed rate payor and customer B is the floating rate payor. During the fall of 1990, if interest rates were to fall the swap dealer would pay less money than it would receive from customer $A$ and it would

162 See FDIC Capital Guidelines, supra note 31, at 11,517; FRB Capital Guidelines, supra note 31, at 4,205 \& 4,217-18; OCC Capital Guidelines, supra note 31 , at 4,182; see also supra note 154 (describing the rationale for a $50 \%$ risk weight and the subsequent Hammersmith \& Fulham ruling).

163 This example is adapted from FRB Capital Guidelines, supra note 31, at 4,208 (Attachment V). In this example, the swap dealer has entered into only one swap with each counterparty. In the real world, a swap dealer may well enter into two or more swaps with a particular counterparty.

The impact of the American bankruptcy laws and the capital adequacy system in the latter type of situation is particularly troublesome. If a counterparty subject to the Bankruptcy Code becomes insolvent, the trustee in bankruptcy would likely try to assume all swaps in which the swap dealer is the net payor and reject all swaps in which the counterparty is the net payor. On the other hand, the swap dealer would, at a minimum, prefer that all swaps be aggregated so that the trustee would have to either assume or reject all of the swaps as a whole. The uncertainty under the Bankruptcy Code with respect to whether swaps would be aggregated creates uncertainty as to the true credit exposure of a swap dealer. This uncertainty in turn affects the amount of capital regulators should require of banks involved in multiple swaps with a single counterparty.

Swap dealers have been active on both the bankruptcy front and the bank capital adequacy front. They have been helping promote the use of carefully drafted swap documentation and statutory changes that would minimize this and other bankruptcy risks and have been seeking to convince bank regulators to weigh the net rather than the gross exposure arising out of swaps with the same counterparties. For background on the bankruptcy aspects of swaps, see FIRREA, supra note 95, Pub. L. No. 101-73 at § 212; Cunningham \& Rogers, The Status of Swap Agreements in Bankruptcy, in INTEREST RATE AND CURRENCY SWAPS 1988, at 187, 211-26; Henderson, supra note 22, at 396-97; Pollard, Treatment of Swaps in Bankruptcy, Butrerworth's J. Int'l Banking \& Fin. L., Dec. 1988, at 514; Senate Judiciary Panel Urged to Amend Bankruptcy Code to Honor Swap Contracts, 52 Banking Rep. (BNA) 870 (1989). For background on how bankruptcy issues can affect bank capital adequacy requirements, see BIS ACCORD, supra note 2, annex 3, at 24; BOE CAPITAL GuIdElines, supra note 119, at 3; FDIC Capital Guidelines, supra note 31, at 11,507; FRB Capital Guidelines, supra note 31, at 4,192; OCC Capital Guidelines, supra note 31, at 4,174; 1988 ISDA Letter, supra note 154, at 3. See generally S. Henderson \& J. Price, supra note 36 , at 163-64 (discussing netting). 
pay more money than it would receive from customer B. The swap dealer would be "in the money" on the first swap, while customer B would be "in the money" on the second swap. As a result of such interest rate movements, assume that the mark-to-market value of swap with customer A is (plus) $\$ 200,000$. This is the amount of damages that the swap dealer would suffer if customer $A$ breached. The value of the swap with customer $B$ is negative; assume that this is (negative) $\$ 250,000$. The capital required under the BIS Accord would be calculated as follows:

\section{Potential Exposure $\quad$ Current Exposure}

\begin{tabular}{|c|c|c|c|c|c|}
\hline $\begin{array}{l}\text { Notional } \\
\text { principal } \\
\text { amount } \\
\text { (dollars) }\end{array}$ & $\times \begin{array}{c}\text { Potential } \\
\text { exposure } \\
\text { conversion }\end{array}$ & $\begin{array}{r}=\text { Potential } \\
\text { exposure } \\
\text { (dollars) }\end{array}$ & $\begin{array}{c}\text { + Replacement } \\
\text { cost }\end{array}$ & $\begin{array}{c}\text { Current } \\
\text { exposure } \\
\text { (dollars) }\end{array}$ & $\begin{array}{l}\text { Credit } \\
\text { equivalent } \\
\text { amount } \\
\text { (dollars) }\end{array}$ \\
\hline $0,000,000$ & .005 & 50,000 & 200,000 & 200,000 & 250,000 \\
\hline $0,000,000$ & .005 & 50,000 & $-250,000$ & - & 50,000 \\
\hline
\end{tabular}

The "credit equivalent amount" of the two swaps collectively would be $\$ 300,000$. We apply the risk weight of fifty percent to the $\$ 300,000$ and find that the swap would require as much capital as the typical loan in the principal amount of $\$ 150,000$.

The amount of capital required for currency swaps is an order of magnitude higher than that required for interest rate swaps. As can be surmised from the fact that the "add-on" for currency swaps is ten times the "add-on" for interest rate swaps, regulators felt that currency swaps were much riskier than interest rate swaps. By way of example, assume that a currency swap was written for $\$ 10,000,000$. Fifteen months into the seven year swap, rates had moved against the dealer so far that the mark-to-market value was eighty-five percent of the notional amount. ${ }^{164}$ At that point in time, the "credit equivalent" amount would be equal to the sum of $\$ 8,500,000$ and $\$ 500,000$, or $\$ 9,000,000$. The amount of capital which would be required on that currency swap, only fifteen months in on a sevenyear obligation, would be equal to that for a $\$ 4,500,000$ loan.

The sets of "conversion factors," "add-ons," and "risk weights" embraced by the regulators are classification-based rules by which regulators assign capital requirements. The conversion factors, to

164 See, e.g., Cooper, Image, Fiction and Fact About Swaps, Euromoney, Jan. 1987 (supplement), at 21 (swaps officer found to his horror that a movement of this magnitude had occurred on a currency swap into which his bank had entered fifteen months earlier). 
which the regulators following the original exposure method adhere, reflect what regulators presume to be the overall credit risk associated with a swap. The add-ons, to which regulators following the current exposure method adhere, reflect what regulators presume to be the potential exposure component of the credit risk associated with a swap. The risk weights reflect a general assessment on the part of regulators in both camps as to the general credit quality of the customers of swap dealers. For convenience, we will refer to these three sets of figures as the "weights" in the BIS Accord.

These weights are not permanent. For instance, the Cooke Committee warned that it "will keep a close eye on the credit quality of participants in these markets and reserves the right to raise the [risk] weights if average credit quality or if loss experience increases." 165 The "add-ons" and "conversion factors" are to be "regarded as provisional" and "may be subject to amendment as a result of changes in the volatility of exchange rates and interest rates." 166 Several months after the BIS Accord was signed, in his parting remarks as he retired from the Cooke Committee, Peter Cooke stressed that the capital formulas were still subject to review. ${ }^{167}$

\section{The Financial Innovation Process and the BIS Accord}

As we have seen, the swaps-related rules of the BIS Accord are complex. There are two reasons for this. First, regulators recognized that if a risk-based capital adequacy approach is going to be effective, ${ }^{168}$ the regulatory "pricing" of subject instruments must be accurate. Capital requirements which are too high or too low in relation to the true credit risk of particular instruments can, in the aggre-

165 BIS Accord, supra note 2, annex 3, at 6; see also FRB Capital Guidelines, supra note 31, at 4,192 (noting that " $[\mathrm{t}]$ he Federal Reserve intends to monitor the quality of credits in [swap] markets and, in the future, might consider, if circumstances so warrant, assigning a 100 percent risk weight to credit equivalent amounts of rate contracts"). See supra note 154 (Hammersmith \& Fulham litigation).

166 BIS ACCORD, supra note 2, annex 3 , at 4.

167 See Huid Muller Takes Over at the Basel Committee, InstrTutional INvestor, Nov. 1988, at 18. Cf. Hearing of the Senate Banking Committee, Federal News Serv., Oct. 25, 1989 (available Nov. 19, 1989, on LEXIS, Nexis library, Omni file) ("The international organization is now studying risk-based [standards] to add additional standards ... . [T] hey haven't even completed their work.") (testimony of L. William Seidman, chairman of the Federal Deposit Insurance Corporation on Oct. 25, 1989).

168 This Article attempts to demonstrate that the process of innovation must be considered if attempts to regulate swaps are to be successful. This Article does not examine any of the purported defects of the BIS Accord apart from those directly related to the financial innovation process. See supra notes 134 \& 159. 
gate, create unacceptable economic results. ${ }^{169}$ These credit risks are complex and so the pricing rules end up that way as well. Second, these swaps-related rules served as the primary mechanism for solving difficult international collective action problems. Absent adherence to such rules - or to the extent that regulators use their judgment in individual cases to override these rules - the international bank regulatory system will be back to the regulatory free-forall which had existed prior to the BIS Accord. Even if there were two approaches to determining credit equivalents - the original exposure method and the current exposure method - they were at least rules which would constrain inappropriate regulatory behavior. Differences in the capital requirements which would be generated under the alternative approaches were predictable and tolerable sacrifices to avoiding regulatory chaos. ${ }^{170}$

Given the complexity of the existing capital adequacy rules, it was not surprising that regulators did not attempt to address the underlying process of financial innovation. The BIS Accord framework, with its reliance on formal rules adopted and kept current by regulators, is largely indifferent to this process. This Article argues that this process undermines the basic integrity of the framework in three related ways.

First, the compelling need for formal rules which regulators of widely differing sophistication can administer will lead increasingly to results that no regulator intends. ${ }^{171}$ The compelling need to avoid complicated rules will generate increasingly heavy social costs. As existing forms of hedging products evolve and new forms arise, more and more products will be squeezed into a single classification. The regulatory "prices" will bear little relation to the true credit risks in a growing number of cases. Constraints on the subtlety of an internationally agreed-upon classification system in the face of the increasing heterogeneity of financial products will result in an increasing difficulty in the "mapping" of any individual type of swap to a correct regulatory price. ${ }^{172}$

I69 See supra notes $141-42$ and accompanying text.

170 For criticism of the existence of two approaches to calculating capital requirements, see Letter from John F. Kooken, Vice Chairman and Chief Financial Officer, Security Pacific Corporation, to William R. Wiles, Board of Governors of the Federal Reserve System, app. 2, at 3-4 (May 10, 1988); 1988 ISDA Letter, supra note 154 , at 4; infra note 173 (discussing effect of judgmental supervision).

171 Cf. M. Kelman, A Guide to Critical Legal Studies 15-63 (1987) (explaining the distinction between use of formal rules and use of ad-hoc situation sensitive decision making).

172 See Powers, Formalism and Nonformalism in Choice of Law Methodology, 52 WASH. 
Second, there is no formal mechanism for changing the capital adequacy requirements on a timely basis. Even if the regulations could mirror changes in volatilities and our theoretical understanding of the ways such volatilities translate to credit risk, it would not be enough. The regulations must also change with the character of hedging products and the relative importance of these products. The BIS Accord fails to establish a formal mechanism to facilitate such revisions. The only way major changes can occur on a coordinated basis is through time-consuming, open-ended negotiations among the regulators of at least the twelve countries involved in the BIS Accord. Absent an unprecedented degree of cooperation, the rules will continually suffer from regulatory lag.

Third, there are subtle informational difficulties, related in some ways to the previous problem. The BIS Accord does not require financial institutions to obtain clearance from regulatory authorities before introducing new products or changing the relative composition of the products they offer. This practice raises two informational difficulties. To begin with, products which arise or become popular only after the BIS Accord will be assigned weights based on a classification system which does not in any way reflect information about their risk characteristics. Moreover, because financial institutions will take the initiative in introducing products, regulators - like competing financial institutions - will necessarily obtain or generate information about the product with a lag. Because of the complexity of these products, the lag could be intolerably long.

\section{A. Formal Rules, Constraints on Subtlety, and the Mapping Problem}

The BIS Accord establishes a formal decisionmaking process under which regulators must, at least in the first instance, ${ }^{173}$ decide

L. Rev. 27, 30-31 (1976) (defining the "mapping" problem); $c f$. Simons, Overinclusion and Underinclusion: $A$ New Model, 36 UCLA L. Rev. 447, 448-49 (1989) (examining the constitutionality of governmental classifications and the "fit" between means and ends, especially with respect to the overinclusiveness and underinclusiveness of the classification).

173 Regulators, of course, can avoid the mispricings generated by the blind application of formal rules by making individual judgments as to the appropriate amount of capital. Indeed, regulators have made clear that such judgments will be made in applying the BIS Accord generally. See FRB Capital Guidelines, supra note 31, at 4,187; FDIC Capital Guidelines, supra note 31, at 11,501; OCC Capital Guidelines, supra note 31 , at 4,169 .

This "solution" has a number of fundamental problems, stemming largely from the kinds of international collective goods problems identified in Part II.B.2. If regulators depart from the formal rules of the BIS Accord in a large number of individual cases, it becomes very difficult to ensure that banks world-wide are 
mechanistically the capital required to be allocated to any given swap by applying simple rules to a limited number of facts. ${ }^{174}$ The amount of capital required on account of a swap is, in the usual case, determined by whether it is an interest rate or a currency swap, its maturity, and its notional amount. This classification system substantially screens from regulatory consideration all other information pertaining to the swap.

Any such rule-bound decisionmaking can result in undesirable results in individual cases because once adopted, the rule alone becomes the source of decision, blind to the policies which generated it. ${ }^{175}$ For example, if we assume that the purpose of a voting age requirement is to screen out immature voters, allowing only those older than eighteen to vote will screen out some who are mature while granting a vote to some who are immature. ${ }^{176}$ However, in deciding to set a voting age, as in other such decisions, the benefits of predictability, ease of application by limiting the scope of relevant information, freedom from arbitrary power and discretion and similar factors ${ }^{177}$ can outweigh the costs of inequitable results in individual cases.

With the BIS Accord, the need for simplicity in the rules was a result of the fact that the rules had to be administrable by even the least sophisticated of regulators and financial institutions in the twelve countries. Since the financial innovation process is most advanced in the United States and the United Kingdom, regulators in other countries do not have the same degree of experience. ${ }^{178}$ Indeed, even the relatively simple classification system originally proposed by the United States and the United Kingdom in $1987 \mathrm{had}$

contributing equally to the maintenance of a healthy international financial system. Unlike the capital adequacy approach, with its heavy reliance on published and objectively verifiable numbers, there is no easy way of comparing the individualized judgments made by regulators. The incentives for regulators to "cheat" in an effort to help their home institutions will serve as a centrifugal force tearing at the burdensharing concepts at the heart of the BIS Accord. Moreover, to the extent that regulators are required to coordinate their departures from the rules in some fashion so as to eliminate cheating, variations on the mapping, obsolescence, and informational problems associated with the BIS Accord arise.

174 See M. Kelman, supra note 171 , at 15 .

175 See Powers, supra note 172, at 28.

176 See M. Kelman, supra note 171 , at 15 .

177 See id.; Powers, supra note 172, at 29-30.

178 See Sillem, supra note 81, at 12-13; see also Shreeve \& McDougall, Quality, Not Quantity, BANKER, Aug. 1987, at 12, 13 (noting that Bank of England "prides itself on having outdistanced other regulatory authorities in providing a formula for assessing the true credit risk" of swaps). 
to be further simplified upon objections of other regulators. ${ }^{179}$ In the end, not even the final BIS Accord system was simple enough. Some countries rejected the "current exposure" approach in favor of the far simpler "original exposure" method, a method which is less accurate from a standpoint of approximating credit risk. ${ }^{180}$

Regulators felt that a relatively simple system would have to suffice, ${ }^{181}$ even though mapping problems with respect even to existing swaps and related financial products were readily apparent. For example, the BIS Accord ignores the type of currencies involved in currency swaps. For example, the movements of the United States Dollar and the Canadian Dollar are more highly correlated than the movements of the United States Dollar and the Swiss franc. The chances of a swap dealer becoming exposed to a large credit risk on the United States Dollar/Canadian Dollar currency swap is, therefore, much lower than on the U.S. Dollar/Swiss franc currency swap. Yet, under the BIS Accord, they are treated alike for purposes of the capital adequacy requirements. ${ }^{182}$

The mapping problems can be especially serious as to more complicated swaps. The notional amounts, specified cash flows, and duration of such swaps could all vary in ways which are not fully captured by the simple categorizations adopted by the BIS Accord. For

179 See Bardos, supra note 111 , at 34 (discussing objections).

180 See supra note 155 and accompanying text.

181 This point was emphasized by Andrew Pople, Banking Supervision Division, Bank of England, in a discussion with the author in London on July 7, 1988. See also The 1987 London Swaps Seminar, supra note 26, at 110 (Carol Sergeant, Banking Supervision Division, Bank of England, noting the need "to produce something that people can understand - the people that operate it in the bank and the supervisors"); cf. Staff Memorandum, Treatment of Interest Rate and Exchange Rate Contracts in the Risk Asset Ratio, reprinted in INTERest RATE and CURRency Swaps 1987, at 289, 297 (1987) [hereinafter Staff Memorandum] (noting that "proposed conversion factors for calculating potential exposure reflect an attempt to strike a reasonable balance between precision and complexity").

182 See Staff Memorandum, supra note 181, at 297; letter from Michael P. Esposito, Jr., Executive Vice President and Chief Financial Officer, to William W. Wiles (June l, 1987).

Under the original exposure approach, the credit equivalent for these two swaps will always be identical. This is so because the credit equivalent is dependent only on the conversion factors, and these factors are the same for United States Dollar/ Canadian Dollar and United States Dollar/Swiss Franc swaps. The results under the current exposure method are likely to be somewhat better. Under the current exposure method, the credit equivalent is dependent on both add-ons and the markto-market values. Although the add-ons for the two swaps are the same, the mark-tomarket value for the United States Dollar/Swiss franc swap will fluctuate more over time. For this reason, under the current exposure approach, the more volatile swap will typically generate a higher credit equivalent. 
example, with respect to the notional amount, there are "drawdown swaps," in which the notional amount increases over the life of the swap to match drawdowns on an extension of credit; "rollercoaster swaps," in which the notional amount first increases and then decreases over the life of the instrument; and "saw tooth swaps," in which the notional amount varies according to a predetermined schedule. ${ }^{183}$ As to specified cash flows, "superfloater swaps" allow parties to exchange payments based in part on a multiple of a floating rate index, while "arrears reset swaps" permit the floating rate payor to pay on the basis of a floating rate index set at the end of each interest period rather than at the beginning. ${ }^{184}$

The durational characteristics of swaps are already quite diverse. In its simplest form, a "puttable swap" allows one of the parties to terminate the transaction before completion of the full term while a "callable swap" gives the fixed rate payer the option of cancelling the agreement, usually on a specified date. ${ }^{185}$ More generally, bank purchases and sales of "swaptions" (swaps with various option features) have become important. ${ }^{186}$ With the exotic commencement and termination features of these instruments, it is doubtful that the general rules of the BIS Accord will lead to accurate regulatory prices.

Moreover, the BIS Accord applies to more than just swaps. Instruments which are closely related to swaps, such as interest rate options and currency options are also subject to the BIS Accord's classification system. Although the payment terms of these contracts are substantially different from those of swaps and the risk characteristics can differ as well, ${ }^{187}$ regulators apparently felt that these products were not important enough to consider separately. ${ }^{188}$ As these

183 See A. Sarwal, supra note 7, at 320-23; When the Swap Meets the Option, EUROMONEY, Apr. 1989 (supplement), at 26, 32.

184 See Puleo, supra note 40, at 32-33.

185 See A. Sarwal, supra note 7, at 320.

186 See Cooper, Still Plenty of Room to Grow, Euromoney, Oct. 1988, at 35, 38; When the Swap Meets the Option, supra note 183, at 32.

187 See, e.g., Shirreff, Caps and Options: The Dangerous New Protection Racket, Euromoney, Mar. 1986, at 26, 33-34; Weiner, supra note 87, at 16 (noting that the pricing of interest rate caps become better understood in 1988).

188 See Swap market regulation: Banks' response to proposed capital ratios must not be overly negative, says Fed, INT'L Fin. REv., May 2, 1987, at 1497, 1499 (noting that the Federal Reserve "did not devote much attention to options because they did not think they loomed large in swaps activity, or large enough to influence risk-weighted capital assessments"). It is unclear to what extent regulators considered the risk characteristics of these other instruments. See, e.g., FRB/BOE Credit Exposure Memorandum, supra note 57, at 325; Staff Memorandum, supra note 181, at 292. 
newer hedging products grow in relative importance, the overall mapping problems associated with the BIS Accord may increase. ${ }^{189}$

The regulators thus established a classification system which was intended to be substantially correct when used to evaluate the simplest and most common types of interest rate swap and currency swaps. Although the evidence is sparse, it appears that the mathematical models on which they relied were fundamentally premised on the kind of "plain vanilla" swaps described in Part I, rather than the more sophisticated types of swaps. ${ }^{190}$

The mapping problem described will only get worse. Of course, as with any rule-based system, there will be an incentive to "walk the line," to try to use the rules to one's own advantage. ${ }^{191}$ But the financial innovation process itself causes a far more fundamental problem. Since current administrative and political realities may prevent a more complex classification system and since the diversity of financial products will grow as financial innovation continues, ${ }^{192}$

189 For example, the market for "caps," "floors," and "collars" is no longer insignificant. Fueled by leveraged buyouts and recapitalizations, these instruments reached $\$ 290$ billion in outstandings by the end of 1988. See Forde, LBOs Spur Rise in Rate Protection Deals; Cap Agreements Surpassed \$290 Billion Last Year: Study, Am. Banker, Mar. 13, 1989, at 2.

Under certain conditions, a bank does not incur any credit risk from entering into these non-swap hedging transactions. For instance, if a bank simply sells an option to a corporation, the corporation is taking a chance on the creditworthiness of the bank, not the other way around.

190 See, e.g., FRB/BOE Credit Exposure Memorandum, supra note 57, at 325-26. In a discussion with the author in London in July 1988, a swaps officer who preferred to remain nameless contended that the Federal Reserve and the Bank of England only looked at "uncomplicated structures."

191 See M. KELMAN, supra note 171, at 41-43 (noting "walking the line" behavior in response to income tax rules); cf. Fingleton, Mutual Admiration, Euromoney, Sept. 1989 , at 27, 27 (author referring to certain Japanese practices in response to the BIS Accord as "doing Trojan work hoovering up the Japanese banks' various BIS-related capital issues").

192 While revolutionary financial products are increasingly less likely to emerge as a general matter, innovation can be expected to continue in the area of swaps and related products. Banks compete not only on the price but on the ability to provide creative new products. Creativity in the swaps and related markets is rewarded by recognition among peers and new business. See, e.g., Cooper, They're Teaching the Old Swap New Tricks, Euromoney, Apr. 1989, at 43 (noting that "the swaps crowd certainly knows how to repackage an old concept, dress it up with new technology, give it a jazzy name, and find new applications all over the globe"); Shegog, Who's Top in Swaps?, Euromoney, Jan. 1987, at 25, 29 (ranking swap houses as to who is the "most innovative in problem-solving"); Strong Pru-Bache Drive Relies on Hi-Tech, Pru Backing, INT'L FIN. REv., Sept. 21, 1985, at 2,315 (noting the preference for sophisticated, "value-added" transactions); The Busy Folks at SecPac Hoare Govett, INT'L FIN. Rev., Jan. 3,1987, at 22 (stating that creativity is rewarded with new business); Tholstrup, Recent Innovations in the Global Swap Markets, reprinted in THE 1987 LONDON 
the system will assign improper regulatory prices with increasing frequency. ${ }^{193}$

\section{B. The BIS Accord and Obsolescence}

Institutionalization of change, as well as the operation of a highly dynamic marketplace, will cause serious problems of regulatory obsolescence. The emergence of new products, and changes in the relative importance of both existing and new products as well as changes in the real or understood riskiness of such instruments all contribute to the need to revise continually the BIS Accord's classification system and the associated weights. ${ }^{194}$ The BIS Accord does not provide a clear mechanism for dealing with this issue.

Even in the purely domestic setting, it is difficult for regulators to keep up with the changing financial scene. ${ }^{195}$ Despite tremendous growth in the swaps market and substantial uncertainty in the law, no Internal Revenue Code section, regulation, or revenue ruling directly addressed the tax treatment of interest rate swaps until the

Swaps SEminar, supra note 26, at 9 (referring to an "onus" on every swap department to innovate and analogizing such departments to the research laboratories of pharmaceutical companies); Weiner, supra note 87, at 16 (highlighting one bank officer who noted the increasing importance of designing interest rate protection products for specific corporate needs); When the Swap Meets the Option, supra note 183, at 26 (quoting a swaps officer as saying that there are now "very few revolutionary products in swaps"); infra note 231 (discussing diffusion of information pertaining to swaps). But of. Keller, supra note 50, at 52 (stating that much financial technology "has become almost run-of-the-mill").

Observers generally believe that new financial products will continue to emerge, although there is dispute over the rate at which this will occur. See CROSS RePort, supra note 3, at 184-86; Finnerty, supra note 3, at 31; Miller, supra note 1, at 471; Muehring, Why Investors are Losing Their Appetite for Eurobonds, INSTITUTIONAL INVESTOR, Oct. 1987, at 281, 285 (describing investor distaste for exotic financial products); $c f$. Rosenberg, The Impact of Technological Innovation: A Historical View, in THE Positive Sum Strategy: Harnessing Technology for Economic Growty 17 (R. Landau \& N. Rosenberg eds. 1986) (quoting the Commissioner of the Patent and Trademark Office as saying in 1899 that "[e]verything that can be invented has been invented").

193 Countries that follow the "original exposure" method for determining capital adequacy will be especially susceptible to this problem. This susceptibility will stem from the fact that under the "original exposure" method, the requisite amount of capital is established entirely by the weights fixed by regulation. In contrast, with the "current exposure" method adopted by the United States and the United Kingdom, the amount of capital is determined by two components; one component (the "add-on") is fixed by regulation and the other component (the "mark-to-market") is established by market forces.

194 Cf. Powers, supra note 172 , at $32 \mathrm{n} .23$ (noting the costs of changing rules).

195 Cf. W. Eskridge \& P. Frickey, Cases and Materials on legislation: Statutes and the Creation of Public Policy 844-91 (1988) (analyzing statutory obsolescence in domestic setting). 
end of 1986. This was nearly eighteen months after the New York State Bar Association Tax Section asked the Internal Revenue Service to rule that payments made pursuant to an interest rate swap are not subject to a thirty percent withholding tax. ${ }^{196}$ The Internal Revenue Service has publicly complained about having to pigeon hole the sophisticated hedging transactions of the 1980s to categories and labels developed in the far less sophisticated financial world of the 1950s and 1960s. ${ }^{197}$

The problem is far worse in the international setting. There is no world banking regulator ${ }^{198}$ with the authority to keep standards current, nor did the BIS Accord establish any mechanism for doing so. By default, the only way the BIS Accord can be updated is through formal or informal coordination among the twelve countries. This process, especially in view of the absence of any explicit attempt to narrow the scope of such renegotiations to "technical" issues of risk assessment, is certain to be cumbersome and untimely. Further, the transaction costs are likely to be enormous in light of the number of parties involved. ${ }^{199}$

The fragmentation of legal and political authority is daunting. Fragmentation of authority in the United States alone has often presented impediments to quick decision making in the area of financial innovations. Turf battles and policy disputes among federal regulatory bodies in the United States foreshadow even greater difficulties within an international system. The experience of the Commodity Futures Trading Commission ("CFTC") in its battles with the Securities and Exchange Commission and others is illustrative. Turf battles appeared early in the CFTC's existence: the dis-

196 See I.R.C. $\S \S 871,881$ (1982 \& Supp. V 1987); Brown, Tax Consequences of Interest Rate Swaps: Characterization by Function, Not Prejudice, 6 INT'L TAx \& Bus. Law. 122, 123-24 (1988).

197 See IRS Official Cites Difficulty Fitting New Financial Products into Tax Code Labels, Daily Tax Rep. (BNA) No. 74, at G-1, G-2 (Apr. 19, 1989).

198 Establishing such an authority at this time would probably be politically impractical. Moreover, if such a regulatory authority were estabished, the likelihood of its behaving in an optimal fashion would have to be studied. Cf. Central Bankers, Bureaucratic Incentives, and Monetary Policy (E. Toma \& M. Toma eds. 1986) (analyzing central bank behavior in accordance with economic theory of bureaucracy); Bruff, Legislative Formality, Administrative Rationality, 63 TEx. L. REv. 207, 227-50 (1984) (discussing internal and external influences on administrative agency decisionmaking); Macey \& Garrett, supra note 93, at 215 (article discussing various bureaucratic and political incentives which cause regulators not to seek optimal level of safety).

199 See Ehrlich \& Posner, An Economic Analysis of Legal Rulemaking, 3 J. Legal STuD. 257, 267 (1974) ("Transaction costs tend to increase rapidly with the number of parties whose agreement is necessary for the transaction to occur."). 
pute over one product extended over a period of years and had to be resolved by congressional action. ${ }^{200}$ New turf battles continue to break out, sometimes spilling over into litigation. ${ }^{201}$

Just as there is not a single regulator responsible for the safety and soundness of United States financial institutions, the world does not have a single regulator overseeing the soundness of global financial institutions. ${ }^{202}$ The closest thing to such an international authority is the Cooke Committee itself. ${ }^{203}$ The Cooke Committee, however, has no formal charter or other legal mandate, ${ }^{204}$ no direct authority over individual private financial institutions, no formal governance or dispute resolution mechanism, ${ }^{205}$ and no direct power to implement any changes in national laws or regulations. ${ }^{206}$ The

200 See Markham \& Stephanz, The Stock Market Crash of 1987 - The United States Looks at New Recommendations, 76 GEO. L.J. 1993, 2025-26 (1988).

201 See, e.g., Markham \& Stephanz, supra note 200, at 2025 n.213 (describing litigation arising from Securities and Exchange Commission's actions "[i]n apparent retaliation" for a controversy over a financial product); see also Chicago Mercantile Exch. v. S.E.C., 883 F.2d 537, 548-50 (7th Cir. 1989) (holding that index participations are futures contracts subject to the jurisdiction of the Commodity Futures Trading Commission, rather than the jurisdiction of the Securities and Exchange Commission); Freitag, Key Ruling on "Basket" Securities, N.Y. Times, Aug. 21, 1989, at D1, col. 5 (noting that the decision in Chicago Mercantile is expected to "set off a turf battle that may not be resolved without legislation that sets forth specific regulatory roles for each agency or that merges the two").

The Commodity Futures Trading Commission and the Securities and Exchange Commission have had their disagreements over swaps as well. See SEC Criticizes CFTC Draft Proposal to Extend Regulation to Hybrid Products, 20 Sec. Reg. \& L. Rep. (BNA) 1348 (Aug. 26, 1988); supra notes 87 \& 88 .

202 See, e.g., R. Pecchioli, Prudential Supervision in Banking 32 (1987) (discussing "the need for an adaptation of the supervisory framework" of international financial institutions); Hackney \& Shafer, The Regulation of International Banking: An Assessment of International Institutions, 11 N.C.J. INT'L L. \& COM. REG. 475, 475 (1986) (noting that "various institutions address different aspects of international banking regulation").

203 See supra note 104.

204 See Bench \& Sable, International Lending Supervision, 11 N.C.J. INT'L L. \& CoM. REg. 427, 431 (1986).

205 The Bank for International Settlements does provide the secretariat for the Cooke Committee. See Flexible Mystique, supra note 28, at 94. As of mid-1989, the institution employed only 360 staff members. See Bank for International Settlement (Advertisement), EcoNOMIST, July 1, 1989, at 79. For an example of an international financial organization with the explicit governance arrangements absent from the Cooke Committee, see generally J. Gold, Voting and Decisions in the INTERNATIONAI MONETARY FUND (1972) (work discussing governance of the International Monetary Fund).

206 See Note, The Proposed Risk-Based Capital Framework: A Model of International Banking Cooperation?, 11 FordhaM INT'L L.J. 777, 783, 795-6 (1988); Cooke, supra note 104, at 151 ("The [Cooke] Committee does not undertake a formal supranational 
Committee derives whatever efficacy and power it has from its stature.

Modifying the BIS Accord would be a lengthy process. First, one or more national regulatory authorities must determine that their problems are so serious that a formal revision is necessary. Second, members of the Cooke Committee must agree to any proposed change. Third, an opportunity for notice and comment on the proposed revision by the financial communities of each respective member country presumably would be given. Fourth, the Cooke Committee must determine the precise contours of the final regulation in light of the respective comments. Finally, the individual national banking authorities must implement the changes. Following a similar process, the original BIS Accord took two years to complete.

Of course, only the most serious changes to the BIS Accord would be subject to this sort of revision process. Moreover, if this sort of process occurs again, it should move at a faster pace because regulators are now more familiar with the issues. Whether the rules under the BIS Accord capital adequacy system are changed through a formal process or more informal means, internationally agreed upon changes are likely to occur slowly. As discussed previously, bank regulators play a dual role. While they are concerned with global financial stability, each regulator also has an interest in promoting the competitive interests of local financial institutions. This conflict of interest, as well as heterogeneity in political, legal and administrative traditions, accounting practices, ${ }^{207}$ financial structures and sophistication among regulators, likely make negotiations difficult. ${ }^{208}$

supervisory role; its conclusions do not have, and were never intended to have, legal force.").

207 The Governor of the Bank of England stated that "[e]ach of us had, at the outset, a fairly clear view that our existing concept of capital adequacy was not only the most appropriate to our individual national circumstances, but also the right one." Leigh-Pemberton, Convergence of Capital Standards and the Lessons of the Market Crash, Bank England Q. Bull., May 1988, at 220.

208 See R. PecchIol, supra note 202, at 21 (discussing different approaches by members of different countries to the supervision of financial institutions); see also Banging heads together, BANKER, July 1989, at 176 (stating that subsequent to the BIS Accord, arguments have "started to break out over the detailed rules governing what should be allowed as capital").

For illustrative examples of problems which have occurred in international coordination as to interpretation and modifications of the BIS Accord, see Keller, Need Capital, Banks? Here's How, Euromoney, Apr. 1989, at 59, 62 (appointment of a formal subcommittee to make a determination as to whether certain securities met BIS Accord's definition of Tier 1 capital). 
The failure of the BIS Accord to make explicit some of the more "political" judgments inherent in its classification system and weights also makes such negotiations difficult. For instance, in establishing the "add-ons" or, in the case of the original exposure method, the "conversion factors," the regulators had in mind some notion of the probability thresholds which should be used to gauge potential exposure as a matter of political judgment. ${ }^{209}$ Had those statistical levels been explicitly set out in the BIS Accord, subsequent negotiations would not need to revisit this key issue. Subsequent negotiations would then have been confined largely to the more "technical" issues having to do with generating the new add-ons and conversion factors consistent with those statistical levels. Because of the failure to explicitly set out the relevant probabilistic thresholds, ${ }^{210}$ subsequent negotiations are much more likely to occur on a far broader front.

The foregoing factors make the maintenance of up to date classifications and weights on either the domestic or international levels difficult. Indeed, even though the BIS Accord was only entered into in mid-1988 and the implementing regulations were not adopted in the United States until early 1989, obsolescence appears to have already appeared as to a previously obscure segment of the swaps market. With "commodity swaps," the cash flow payments are tied to fluctuations in the price of commodities rather than fluctuations in the interest rates or exchange rates. An airline, for instance, may wish to protect itself against a rise in the price of jet fuel by using a commodity swap where the cash flows are tied to the price of jet fuel. ${ }^{211}$

As with interest rate and currency swaps, banks may stand in the middle and thus be exposed to credit risk. Despite this credit risk, the BIS Accord and the United States implementing regulations

209 Staff Memorandum, supra note 181, at 289, 290.

210 Cf. 1988 ISDA Letter, supra note 154, at 6 (swap dealers expressing puzzlement over the theoretical justification for differences in the relative weights for interest rate swaps and currency swaps under the original exposure method and the relative weights under the current exposure method); Scott, Scholarship in Banking Law: An Introduction to the Symposium, 49 OHı ST. L.J. 1183, 1186 (1989) ("[T] he final target capital figure (eight percent of risk-adjusted assets), in particular, apparently floated down from Mt. Sinai (or Mont Blanc), for no theoretical or empirical foundation was given.").

211 For descriptions of commodity swaps, see Brody, Commodity Financiers Sharpen Up, Euromoney, Aug. 1989, at 38; Commodity Swaps: A Risky Business, ECONOMIST, Sept. 2, 1989, at 76 [hereinafter Risky Business]; Ireland, Mexcobre Loan Deal Repays Debt, CoRp. FIn., Aug. 1989, at 11; Angrist, Big-Stakes Hedge Starts Branching Out, Wall St. J., Sept. 26. 1989, at C1, col. 2. 
appeared to have ignored commodity swaps for purposes of establishing the classification system and in generating the weights. The BIS Accord applies to "interest rate contracts" and "exchange rate contracts." These terms in turn are defined to include various identified hedging products pertaining to interest rate risk and exchange rate risk as well as "similar instruments." 212 The United States implementing regulations use similar formulations. Absent an expansive reading of the "similar instruments" language, commodity swaps fall outside of the swaps-related capital adequacy provisions. ${ }^{213}$ Similarly, there is no indication whatsoever that anything but interest rate and exchange rate volatilities were used to generate the weights adopted by the BIS Accord and the implementing regulations. Only through happenstance would those volatilities correspond to the volatilities associated with the price of jet fuel or other commodities. Finally, recognizing that regulators are likely to deem that the swap capital requirements are applicable to commodity swaps, a prudent bank will have to determine whether to classify a commodity swap as a currency swap or an interest rate swap and to resolve other difficulties in calculating the amount of capital required.

This omission was understandable. While regulators were aware of the existence of commodity swaps even prior to the BIS Accord, the market was relatively small and obscure. ${ }^{214}$ Taking these commodity swaps into account may have introduced unwarranted complexity into the capital adequacy system. However, the July 1989 decision on the part of the Commodity Futures Trading Commission ("CFTC") not to regulate these commodity swaps (under specified conditions) gave impetus to an increase in the

212 BIS AcCord, supra note 2, at annex 3.

213 See supra note 120 and accompanying text. Bank regulators are likely to read the language expansively, especially in view of pre-BIS Accord suggestions that commodity swaps would be subject to capital adequacy requirements. See National Bank Acting as Principal in Commodity Price Index Swaps with Customer, Comptroller of the Currency No-Action Letter, [1988-89 Transfer Binder] Fed. Banking L. Rep. (CCH) I 84,034, at 76,641 (July 20, 1987) [hereinafter Chase Letter].

214 The Chase Manhattan Bank, for instance, requested and obtained a "no objection" letter in mid-1987 from the Office of the Comptroller of the Currency allowing Chase to engage in commodity swaps under certain specified circumstances. See Chase Letter, supra note 213 , at 76,638 . For a sense of the size of the swaps market prior to the July 1989 CFTC decision, see Cooper, They're Teaching the Old Swap New Tricks, Euromoney, Apr. 1989, at 46 (describing the origins of commodity swaps); Horowitz, Bankers and Brokers Gear Up for Action in Fledging Market for Commodity Swaps, AM. BANKER, July 20,1989, at 1 (estimating that only 130 commodity swaps had been consummated in the previous two year period and noting that such numbers "pale in comparison" to those of the interest rate and currency swaps market). 
number of participants in and the expected number of commodity swaps. ${ }^{215}$ The BIS Accord and implementing regulations had, through their silence, become obsolete as to an important segment of the swaps market. As of October 1, 1989, no domestic or international rules had yet been generated as to precisely how much capital should be allocated to these swaps.

\section{Informational Hurdles}

Ideally, regulators should assign regulatory prices to hedging products on the basis of current and accurate information about such instruments. Regulators "cannot ride a bicycle to reach their conclusions while the market is driving a Porsche."216 Daunting as the informational problems are in formulating rational regulatory policies in general, ${ }^{217}$ the BIS Accord and the financial innovation process combine to create extraordinary informational burdens.

\section{Bank Initiative and Informational Lags}

Generally speaking, banks may develop a swap or related product without any clearance from or registration with banking authorities. $^{218}$ There is an inevitable informational lag built into the system. $^{219}$ Banks typically invent and introduce the product first.

215 See Angrist, supra note $21 \mathrm{I}$ (quoting former counsel to the chairman of the CFTC as saying that "[c]ommodity swaps have progressed faster and further in the two months since the CFTC policy statement than did interest-rate swaps in two years when they began"); Horowitz, supra note 214, at 1 (stating that several commercial and investment banks are planning to "lunge into the emerging commodity swaps market following the Commodity Futures Trading Commission's decision"); Risky Business, supra note 211, at 76 (noting that more banks will act in a principal capacity as commodity swaps after the CFTC action); CFTC Swaps Policy Statement, supra note 87 (discussing the July 1989 CFTC action). But cf. Brody, supra note 211 , at 42 (commodity swaps were flourishing even prior to July 1989 CFTC action).

In contrast to the BIS Accord and the United States implementing regulations, FIRREA explicitly recognizes commodity swaps. See FIRREA, supra note 95, Pub. L. No. 101-73, § 212, 103 Stat. 125, 127 (1989) ("commodities contracts" and "swap agreement" placed in the same category of financial contracts).

216 Cook, Risk Assessment and Disclosure: Discussion Summary, in New Financial InSTRUMents: Disclosure and ACCOUNTING 209, 210 (1988).

217 See S. Breyer, Regulation aNd Its ReForm 109-12 (1982); McGarity, Regulatory Analysis and Regulatory Reform, 65 TEx. L. REv. 1243, 1276-84 (1987); Sappington \& Stiglitz, Information and Regulation, in Public Regulation: New Perspectives of Institutions and Policies 3-13 (E. Bailey ed. 1987).

218 See Puleo, supra note 40, at 28; cf. supra note 87 and accompanying text (discussing minimal regulation of new bank swap products).

219 Cf. Hiltzik, Banks Enter New World of High Risk, L.A. Times, Oct. 27, 1985, Part V, at 1 , col. 6 (quoting a regulator from the Office of the Comptroller of the 
The regulators must become aware of the existence of the product and then obtain or generate information on the risk characteristics of the new product so as to determine whether the existing classification and weighting system assigns a proper capital price.

If history is any guide, this lag can be lengthy. For instance, one Japanese regulator conceded in late 1986 that it was "only recently" that he and his colleagues had become aware of the implications of swaps. ${ }^{220}$ Internal Revenue Service officials were "alarmed, even infuriated" by certain tax-driven swaps whose use had been widespread but kept "under wraps" for months. ${ }^{21}$ Regulators' information about risks also lagged. As late as April 1986, the associate director of Economic and Policy Analysis at the Office of the Comptroller of the Currency stated that he "definitely [did not] have sufficient data to evaluate the risk" posed by interest rate swaps. ${ }^{222}$

Information lags have also been pervasive as to financial innovations in general. An officer at the Internal Revenue Service has conceded that financial markets have been inventing new products faster than the Internal Revenue Service can keep up with. ${ }^{223}$ The general counsel of the Commodities Futures Trading Commission learned about one form of instrument arguably within his jurisdiction when he read about it in the Wall Street Journal. ${ }^{224}$

Even among private financial institutions themselves there have been serious information lags. Toward the end of 1986, the most sophisticated of the swap houses realized that the fundamental theo-

Currency as stating that "if you believe in a free-market system, you'll always have regulators catching up with the market").

220 See Fingleton, Worrying About a Crash, Euromoney, Sept. 1986, at 110, 117; see also Shegog, Riding Cross-currents in Swaps, Euromoney, Sept. 1987, at 222, 226 (noting that "regulators have only just got up to speed with the first couple of generations of swaps"); Shirreff, The Fearsome Growth of Swaps, Euromoney, Oct. 1985, at 247, 253 (discussing the invitation of swaps officers to the Federal Reserve Board in 1984 to explain the swap market).

221 See Belton, Troubled Waters Ahead for Tax-Driven Swaps, Investment Dealers' Digest, Nov. 14, 1988, at 17, 19; cf. Winkler, IRS Acts to Plug Big Loophole on InterestRate Swaps, Wall St. J., Feb. 13, 1989, at CI, col. 3 (reporting the new IRS ruling closing the loophole). This IRS ruling is set out in I.R.S. Notice 89-21, 1989-8 I.R.B. 23 (Feb. 21, 1989).

222 See Regulators Expected to Require More Disclosure, Regulation of Swap Market, 46 Wash. Fin. Rep. (BNA) 531, 532 (Apr. 7, 1986); cf. Mayer, supra note 121, at 15 (suggesting that "bank examiners are at the mercy of the banks in determining the value of options and swaps"); Miller, When Swaps Unwind, Institutronal INvestor, Nov. 1986, at 165, 166 ("Of course, when we talk to central banks, we always say there isn't any [risk]. ..").

223 See Evans, Legislative Solutions Needed for New Financial Producls Problems, 40 TAX Notes 332, 332 (1988).

224 See Roberts, supra note 22, at 16. 
ries used to analyze the cash flows generated during the life of a swap were wrong. ${ }^{225}$ They quickly began using more advanced theories which gave them a strong competitive advantage for quite some time. ${ }^{226}$ Such knowledge apparently gave the big houses a pricing edge of three to ten basis points over the houses which were unaware of the newer thinking, ${ }^{227}$ a remarkable advantage relative to the margins then prevailing. ${ }^{228}$ Similarly, some dealers came to understand more quickly than others the subtle bankruptcy problems associated with swaps ${ }^{229}$ and the credit risks of swaps generally. ${ }^{230}$

Although the maturation of the swap and related markets and the continuing diffusion of pertinent information ${ }^{231}$ ameliorate the informational lag problem, the complexities can still overwhelm. For example, in July 1988 the Federal Reserve Bank of New York forced Bankers Trust Company to slash $\$ 80$ million from its foreign exchange trading income recognized in a regulatory financial report for the fourth quarter of $1987 . .^{232}$. Although the New York Federal Reserve would not comment on why the bank was asked to make the

225 This, of course, did come as a surprise. In June 1985, for instance, a major swap dealer had claimed that the swaps area no longer required people who were "financial wizards," and that now "all you need is a solid command of arithmetic." See Weiner, Banks' Swap Business Booms, AM. Banker, June 10, 1985, at 1.

226 See Cooper, Swap Houses Switch to New Values, Euromoney, Jan. 1987, at 32 (new zero-coupon method of valuing swaps "gives the big houses a pricing edge of anywhere from 3 to 10 basis points").

227 See id.

228 See id.

229 For instance, in the early years of the swap market, many people did not fully understand the impact of the automatic stay and executory contract provisions of the Bankruptcy Code. See, e.g., Henderson, Termination of Swaps Under US Insolvency Laws, INT'L Fin. L. REv., Dec. 1984, at 17, 21; cf. supra note 163 (describing certain other bankruptcy issues in the swaps context).

230 See Kreca, Pricing versus Credit: An Art or a Science?, InTERmarket, May 1986, at 41 ("In the early days, a few [swap] participants understood the credit issue; the rest didn't." (quoting Jonathan Berg, deputy head of capital markets for Bankers Trust)); Weiner, '89 Will Bring Closer Scrutiny of Swap Product, AM. Banker, Jan. 3, 1989, at 3 (reporting that "some institutions didn't recognize swaps as having risk" (quoting Donald Layton, managing director of Manufacturers Hanover Trust Co.)).

231 See supra note 192 and infra 279-91 and accompanying text. Information on the economics of swaps and related financial products is now much more widely diffused. Software for swap analysis and risk management of varying degrees of sophistication and accuracy is now commercially available from a dozen developers. See Antl, All kinds of bells and whistles, Euromoney, Aug. 1989, at 80-87; $c$. Investment Support Systems Inc., Futrak Risk Management Software from Investment Support Systems, Inc. (undated) (sales brochure describing trading and risk management software available from one leading vendor).

232 See Fed Orders Bankers Trust to Slash 1987 Foreign Exchange Trading Income, Banking Rep. (BNA), July 25, 1988, at 117; Horowitz, Regulators Force Bankers Trust to Cut Eamings by $\$ 80$ Million, Am. BANKER, July 21, 1988, at 1 ; $ø$. Stern, (Dangerous) Fun 
restatement, a bank spokesman attributed the $\$ 80$ million discrepancy to the over-the-counter currency options market and implied that some of the bank's options may have been mispriced. ${ }^{233}$

\section{Diffusion and Informational Lags}

While information does diffuse and the swap and related markets have been maturing, there are several factors which make it likely that regulators will have a more difficult time than private financial institutions in keeping up. Regulators will, to a degree, need to resort to direct or indirect pressure or outright compulsion.

To the extent that information diffuses because of personnel movement, regulatory authorities are generally out of the loop. In the swaps area, there have been continual personnel moves from one institution to another. ${ }^{234}$ The impact on financial institutions from these departures in certain circumstances is so extreme that regulators have expressed concern. ${ }^{235}$ Yet, as a result of these moves, information spreads. Referring to one new technique, one observer noted that "[a]s personnel have moved from one team to another, taking bright ideas with them, so the number of players who can wield those tools has grown from a handful a year ago to eight or 10."236 Some moves have inspired litigation. ${ }^{237}$ In one notable case, Citibank sued a leading investment bank in connection with the defection of a swap team. As part of the settlement, the investment bank agreed to return all the documents that the swappers had taken with them when they left Citibank; however, the settlement apparently did not prevent the team from either participating in the swaps

and Games in the Foreign Exchange Market, Forbes, Aug. 22, 1988, at 69, 70 (discussing dangers in banks allowing options traders to price their portfolios).

233 See Mayer, supra note 121, at 15.

234 See, e.g., The Way to Any Market, Euromoney, Nov. 1983, at 64, 67 ("Continental has been a breeding-ground of swap expertise. The early team included John Price, who moved to Bankers Trust and this year set up a private swap consultancy; Peter Ogden, who pioneered swaps at Merrill Lynch and was headhunted by Morgan Stanley; Amir Eilon, now at Samuel Montagu; Allan Wilson who had a spectacular 15 months at Credit Suisse First Boston . . . before returning to Continental."); Sterngold, Raiding of the Rate Swappers, N.Y. Times, Jan. 14, 1986, at D1, col. 3 (discussing Citibank's loss of three teams of swappers to other financial institutions).

235 The Bank of England has publicly made clear its displeasure over the practice of banks which enter a new area after poaching whole teams of people from competitors, leaving the competitors without key talent. See Fingleton, supra note 220 , at 117 .

236 Shegog, Riding Cross-Currents in Swaps, Euromoney, Sept. 1987, at 222, 224.

237 See, e.g., Mayer v. Morgan Stanley \& Co., 703 F. Supp. 249 (S.D.N.Y. 1988) (litigation involving the departure of a Morgan Stanley vice president). 
business or from using the allegedly proprietary materials it had taken. ${ }^{238}$

Although personnel movement can result in diffusion of information, the government is unlikely to solve its informational lag problem by hiring swaps personnel from private industry, at least in the United States. One reason is that salary differentials between the private sector and the public sector can be enormous in the financial innovations area. In early 1989, the Chairman of the Federal Reserve Board had a salary of $\$ 89,500$ and most federal banking regulators were making even less. ${ }^{239}$ In 1985 , top people in the swaps area were averaging at least $\$ 300,000$ to $\$ 500,000$; their most senior underlings were making between $\$ 150,000$ and $\$ 300,000 . .^{240}$ At one investment bank, a finance expert starts at $\$ 80,000.241$ Although important legislative and administrative steps were taken in late 1989 to improve the pay scale of government bureaucrats, ${ }^{242}$ gaps in public and private pay at the top levels in the financial industry probably will persist. ${ }^{243}$

238 See Sterngold, supra note 234, at D4, col. 6.

239 See Bartlett, A Stronger Savings Regulator, N.Y. Times, Jan. 24, 1989, at D1, col. 3; id. at D7, col. 4 (showing salaries of top-level staff at Federal Home Loan Bank Board, Federal Reserve, Comptroller of the Currency, and the Federal Deposit Insurance Corporation); of. Adequacy of Examination Levels and Compensation: Hearing Before the Subcomm. on Financial Institutions Supervision, Regulation and Insurance of the House Comm. on Banking, Finance and Urban Affairs, 101st Cong., 1st Sess. 113-21 (1989) [hereinafter Bank Supervision Hearings] (discussing staff salaries at the Office of the Comptroller of the Currency relative to those of other federal banking regulators and salaries received by departing executives); infra note 242 (discussing pay increases for federal banking officials).

240 See Kolman, The Sultans of Swap, Institutional Investor, Oct. 1985, at 258; see also Mayer, $703 \mathrm{~F}$. Supp. at 251-52 (finding that expected compensation for vice president in a swap group in Tokyo office of investment bank was $\$ 500,000$ to $\$ 600,000$ in 1987).

241 See Uchitelle, supra note 9, at D4, col. 3.

242 See, e.g., FIRREA, Pub.L.No. 101-73, § 1202, 103 Stat. 183 (1989) (statutory provision authorizing Office of the Comptroller of the Currency to provide compensation comparable to that provided by any other federal bank regulatory agency); Fed Hikes Salaries to Keep Top Employees Competitive, Bank LetTER, Oct. 9, 1989, at 7 (available Nov. 12, 1989, on LEXIS, Nexis library, Omni file) (describing substantial across-the-board pay increase for officials at Federal Reserve Board, with the top salary being raised to $\$ 130,900$ from $\$ 82,500$ ); N.Y. Times, Nov. 19,1989 , at 18 , col. 1 (describing pending legislation as to the salaries of lawmakers, federal judges, and top government officials).

243 Alas, the availability of work on Wall Street is cyclical. Many leading Wall Street executives are considering two options: "lopping off large portions of their firms which just a few short years ago would have been considered essential to their business, or reducing salaries and bonuses drastically." Bartlett, Why Wall Street's So Topsy-Turyy, N.Y. Times, May 7, 1989, § 3, at 1, col. 3. Actual or threatened layoffs in the private sector could result in new government personnel. 
Another reason to doubt that the government will benefit from significant personnel migration is that some of the non-pecuniary benefits which motivate people to government service in the United States do not exist in the financial innovations area. ${ }^{244}$ The dream of inter-planetary voyages which may motivate a scientist to work for NASA has no obvious parallels in the financial innovations area.

Since mass migration of personnel from industry to government is unlikely, regulators must, absent government compulsion, depend upon cooperation from the financial institutions or generate the information themselves. But as for genuinely new information, cooperation is unlikely to be sufficient because the nature of the information needed by bank regulators is extremely sensitive. The regulator needs not only the blueprints for new financial products but the equally proprietary and expensive test results as to risk and other characteristics.

If competitors discovered this information, it would deprive the innovator of lead time and impose on it a material cost disadvantage. ${ }^{245}$ Risk information is so central that the mechanisms used by financial institutions to simply monitor their own overall risk exposure can be used to enter into appropriate hedging transactions. ${ }^{246}$

A financial institution, if it is to cooperate with regulators, must be certain that any information it volunteers will not be available to competitors. No such assurance can be made. Any information given by an institution to the regulatory authority of one country may be considered by the regulatory authorities of eleven other countries during the course of international negotiations and rulemaking. Inadvertent leaks of information aside, regulators might be required by law to provide the public access to such information.

In the United States, for example, ${ }^{247}$ the Freedom of Informa-

244 This discussion concerns only the large-scale migration of researchers from the private sector to the public sector. It is not meant to suggest by any means that the quality of research or researchers is lower in government than in the private sector. Indeed, the extraordinary quality of the economists at the Federal Reserve, to take just one example, is widely recognized.

245 Cf. McGarity \& Shapiro, The Trade Secret Status of Health and Safety Testing Information: Reforming Agency Disclosure Policies, 93 Harv. L. REv. 837, 849 (1980) (discussing disclosure of health and safety testing data of, among other things, new chemicals).

246 See Shale, The Great Risk-Management Systems Failure, Euromoney, Feb. 1989, at 66, 70 (discussing Merrill Lynch's use of its investment analysis system to hedge various option positions).

247 For a comparison of policies of various nations pertaining to the rights of access to government information, see Relyea, Business, Trade Secrets, and Information Access Policy Developments in Other Countries: An Overview, 34 ADMIN. L. REv. 315 (1982). 
tion $\mathrm{Act}^{248}$ and related access statutes ${ }^{249}$ may give competitors the legal right to access to the information. ${ }^{250}$ Under the Freedom of Information Act, federal agencies are under a general obligation to make their records available to the public without any consideration of the motives of the person requesting the information. ${ }^{251}$ Although the principal purpose of the statute is to inform citizens about the operations of government, it is being used increasingly as a tool for industrial espionage. ${ }^{252}$ Such laws may result in federal agencies becoming conduits for the passage of confidential information. ${ }^{253}$ Existing exemptions from the Freedom of Information Act, construed in light of applicable Supreme Court precedent and current Federal Reserve Board regulations, would provide scant comfort to a financial institution. ${ }^{254}$

2485 U.S.C. $\$ 552$ (1982 \& Supp.V 1987).

249 See 2 J. O'Reilly, Federal Information Disclosure: Procedures, Forms AND THE LAW \& 23.01 (1988) (discussing government openness statutes); see also 2 B. Braverman \& F. Chetwynd, Information Law: Freedom of Information, Privacy, Open MeEtings, Other Access Laws $\$ \S 22-1$ to 22-6.4 (1985) (discussing government openness provisions).

250 This Article focuses on the impact of the Freedom of Information Act and similar access laws on the willingness of financial institutions to share information with regulators. Such laws could also have the effect of discouraging financial innovation by decreasing the ability of financial institutions to fully capture the benefits of their work in financial research and development. The ability to capture the benefits - the "appropriability" of such benefits - is an important factor in influencing the amount of technological research and development. See, e.g., Isaac \& Reynolds, Appropriability and Market Structure in a Stochastic Invention Model, 103 Q.J. EcoN. 647, 647 (1988) (stating that appropriability is one of two factors that supposedly serve as incentives for investment); see also W. CASEY, J. MARTHINSEN \& L. Moss, ENTREPRENEURShip, Productivity, AND the Freedom of INFormation ACT 5 (1983) (arguing that the Freedom of Information Act is an independent cause of the technological innovation slump troubling the United States economy because of failure to protect from disclosure "circumstantially relevant business information"). 251 See 5 U.S.C. \$ 552(a)(3) (1982 \& Supp. V 1987).

252 See Note, Protecting Confidential Business Information from Federal Agency Disclosure After Chrysler Corp. v. Brown, 80 CoLum. L. REv. 109, 113 (1980).

253 See, e.g., O'Reilly, Free Business Secrets: With love, from Uncle Sam, Across THE BOARD, June 1983, at 8 (noting that federal information law has forced firms to share confidential information with competitors). But see McGarity \& Shapiro, supra note 245, at 837-88 (noting that private firms have successfully forestalled efforts by agencies and interested citizens to have the contents of products disclosed, by claiming that such data are protected trade secrets). There have already been efforts to gain information through the Freedom of Information Act in the financial innovations area. See Epstein, Researching for New Contracts, EuromonEy, Sept. 1986, at 357,359 .

254 See 5 U.S.C. § 552(b)(4) (1982 \& Supp. V 1987) ("exemption 4" to the Freedom of Information Act); 12 C.F.R. $\$ 261.1$ - .8 (1987) (Federal Reserve Board's Freedom of Information Act regulations); W. CASEy, J. MATHINSEN \& L. Moss, supra note 250 , at 19 (noting the ambiguity of exemption 4's language); McGarity \& 
Of course, regulators could independently develop information about new financial instruments rather than relying on information from the private sector. Unfortunately, the actual behavior of new financial instruments often departs quite markedly from that predicted by theory. ${ }^{255}$ To understand the price and risk characteristics of these instruments one must also have a keen sense what the market will pay, regardless of the computer predictions of some abstract model. ${ }^{256}$ Although the transactional expertise of the traders in the capital markets at the Federal Reserve Bank of New York ${ }^{257}$ and their counterparts abroad is enormously helpful, the lack of direct transactional experience in developing, pricing, and hedging new financial products will nevertheless hinder the ability of bank regulators to accurately forecast the precise risk characteristics of particular products. $^{258}$

Shapiro, supra note 245 , at 858 (explaining the various laws relating to the release by federal agencies of proprietary information); O'Reilly, Regaining a Confidence: Protection of Business Confidential Data Through Reform of the Freedom of Information Act, 34 Admin. L. Rev. 263 (1982) (advocating Congressional action as to exemption 4 cases); $c$. 15 U.S.C. $\S 4305$ (Supp. V 1987) (exemption from Freedom of Information Act for certain information provided pursuant to the National Cooperative Research Act of 1984).

255 See French, The Comeback of the Number-Crunchers, Euromoney, Oct. 1988, at 69, 72 (explaining how theoretical bond valuations can be wrong); $c f$. Hansell, Risk busters, InstrTutional InVESTOR, Aug. 1988, at 134, 136 (discussing reliance on experiments); Shirreff, Caps and Options: The Dangerous New Protection Racket, EuRomoney, Mar. 1986, at 26, 32 (market prices for options departing from theory); Bartlett, Why Wall Street's So Topsy-Turoy, N.Y. Times, May 7, 1989, § 3, at 1, col. 2 (describing the belief of investment banks that having a corporate bond underwriting unit helps them price deals in the merger context).

256 See Hansell, supra note 255, at 136 (quoting Daniel Napoli, chairman of Merrill Lynch Government Securities, as saying that "[c]omputers don't buy bonds").

257 In 1984, the Federal Reserve Bank of New York traded currency and securities valued at approximately $\$ 600$ billion for the accounts of the Treasury, the Federal Reserve System and foreign central banks. See Williams, The Inaction That Makes Things Happen, N.Y. Times, Dec. 30, 1984, § 3, at 8, col. 3.

258 Cf. Oversight of the Securities and Exchange Commission and the Securities Industry: Hearing Before the Subcomm. on Securities of the Senate Comm. on Banking, Housing, and Urban Affairs, 100th Cong., 1st Sess. 21 (1987) (testimony of Donald B. Marron, Chairman and CEO of Paine Webber Group, Inc.). Marron stated that:

In order to deal with the proliferation of new products being offered by the securities industry, we believe that the SEC must accelerate its efforts to acquire expertise in those products. Since the Commission's staff generally has no "hands on" experience in the operational side of the financial services industry, it is desirable for them to obtain second-hand experience and guidance through the assistance of industry representatives. 
IV. Dealing with Dynamism: Points of Stress and InCRemental Changes

\section{A. The Need for Incrementalism and the Scope and Type of Change}

Milton Friedman once said that the safest place of all is jail: not much happens there. ${ }^{259}$ To their credit, the regulators who formulated the BIS Accord did not try to keep the world's financial institutions fully protected from the perils of the dynamic new financial world outside the big house. ${ }^{260}$ Instead, through a plan which is remarkable in its very implementation and admirable for its analytical sophistication, the behavior of banks in the outside world is carefully channeled to take into account known dangers.

Unfortunately, the BIS Accord is incomplete in a conceptually important way. As discussed previously, ${ }^{261}$ the BIS Accord deals with certain known financial instruments, not with the underlying process by which they emerged. However, the massive amount of public and private energy invested in generating the provisions, the costs of any new swaps regulatory system and the historical background to the swap-related provisions make wholesale rejection of the BIS Accord inconceivable in the short run.

An overview of the massive public and private investment in the development of the BIS Accord and the investment now going into its implementation provides an insight into some of the forces which militate against wholesale change. Economists, lawyers, and others in the government sector have devoted years to developing and revising the capital adequacy provisions which ultimately led to the BIS Accord, especially those pertaining to swaps and related products. Regulators have not only reached hard-fought compromises in the BIS Accord, but have had to determine how to implement the BIS Accord in their own countries as well. ${ }^{262}$ Moreover, efforts have been underway to encourage implementation of standards consistent

259 See Securities Futures Market Credit Protection Act: Hearings on H.R. 3597 Before the Subcomm. on Domestic Monetary Policy of the House Comm. on Banking, Finance and Urban Affairs, 100th Cong., 2d Sess. 24 (1988) (Statement of Professor Merton Miller quoting Friedman).

260 As a practical matter, this would be nearly impossible. See, e.g., Pitman, Swooping on Swaps, Euromoney, Jan. 1988, at 80 (Mark Ferron, Vice President of Security Pacific Hoare Govett, quoted as saying that "[a]nyone who thinks he can put swaps back into the bottle is someone who spends most of his life with one").

261 See supra notes 194-215 and accompanying text.

262 See supra notes 149-167 and accompanying text. Regulators have had to deal with a number of ancillary issues as well. See, e.g., Fed Lets Japanese BHC's Act as Interest Rate Swap Broker, Offer Financial Advice, 53 Banking Rep. (BNA), July 3, 1989, at 7 
with the BIS Accord on the part of countries not party to the BIS Accord. ${ }^{263}$

Participants in the private sector have also devoted significant resources to the BIS Accord. They have not only spent time analyzing and seeking to influence each of a series of proposals but are engaged in extensive long-term planning in order to comply with interim and final BIS Accord requirements. ${ }^{264}$

Another obstacle to outright rejection of the BIS Accord is the fact that such an action would trigger a whole new set of direct public and private costs in the formulation, revision, international negotiation and domestic implementation of new regulations. These direct costs, along with the indirect costs of delay and uncertainty may well outweigh the benefits of the alternative to the capital adequacy approach. Approaches radically different from the capital adequacy approach are, in view of the complexity of the subject matter, particularly likely to involve high costs of these sorts.

Finally, the effort to regulate swaps and related products on a coordinated basis proved possible, in large part, because it took advantage of and contributed to a longstanding international momentum to establish common capital adequacy standards with respect to bank activities generally. Absent such a driving force, it is not clear whether the international collective action issues inherent in dealing with these issues can be overcome.

In view of these concerns, any move away from the BIS Accord's capital adequacy approach should be incremental in both scope and method. ${ }^{265}$ The BIS Accord's capital adequacy approach should be used in as many circumstances as possible. In circumstances where a new method is necessary to deal with the problems raised by the

(adjusting for Japanese banking and accounting practices in determining capital adequacy for United States purposes).

263 See Jones, Pillars of the Community, Banker, July 1989, at 38, 39; Banging Heads Together, BANKer, July 1989, at 176; $c f$. BANK FOR INTERNATIONAl SeTtlements, 59 TH ANNUAL REPORT: 1ST APRIL 1988-31 ST MARCH 1989 at 194-95 (describing how "many other countries with major international banks have already indicated a desire to ensure that their own supervisory arrangements are in line with the new standards").

264 See, e.g., Keller, Need Capital, Banks? Here's How, Euromoney, Apr. 1989, at 59 (discussing banks' efforts to raise the requisite amount of capital); Rehm, Money Centers Prepare for Capital Rules; Cost of Backing Higher-Risk Products Will Affect Pricing, AM. BANKER, Nov. 28, 1988, at 1 (describing banks' reexamination of all business lines in light of capital adequacy rules); supra notes 141 \& 145.

265 Cf. R. Dahl \& C. Lindblom, Politics, Economics and Welfare: Planning and Politico-Economic Systems Resolved into Basic Social Processes 82-85 (1953) (describing and analyzing incrementalism as a method of social action). 
financial innovation process, the new method should not present too radical a departure from the old.

The BIS Accord works best in regulating those plain vanilla swaps which were most popular at the time of the BIS Accord. It is the risk characteristics of those financial products which the regulators had in mind in designing the classifications and setting the weights. The BIS Accord's scope should be limited to those products.

The more a hedging product departs from such plain vanilla swaps, the more likely mapping, obsolescence or informational problems will lead to inaccurate regulatory pricing. Products most likely to fall outside the competence of the BIS Accord regime are products which did not exist at the time of the BIS Accord. The characteristics of the new financial products, when slotted into rules designed for other products, could trigger capital requirements which are inconsistent with their actual risk characteristics. As discussed earlier, only through a combination of luck and foresight would such regulatory pricing be correct in this context. The kinds of factors creating regulatory lag and informational problems in the financial innovation context will conspire to hinder efforts on the part of regulators to continually modify the BIS Accord in step with the emergence of important new financial products.

Another category of financial products which poses problems is the class of products which existed prior to the BIS Accord's adoption, but become popular subsequently. At the time of the BIS Accord, the products may have been so unimportant that they did not influence the categories or weights established; errors in the regulatory pricing of these products could be safely ignored. If these products have become prevalent in the market overall or become prominent in the portfolio of any single bank, the pricing inaccuracy may reach unacceptable levels.

A final category of financial products which poses problems is the class of products which simply are not and never will be popular. Whether they existed at the time of the BIS Accord or arose subsequently, these products are a only small part of the market on an individual basis. In view of the limitations on the subtlety of any classification-based system, the kind of system created by the BIS Accord can never adequately deal with these products.

These are three of the categories of financial products which do not fit neatly within the framework of the capital adequacy system established by the BIS Accord. The scope of any change to this system should be limited to these categories of financial products. The 
BIS Accord should be revised to set out explicitly the kinds of instruments for which it was designed. All other hedging products creating credit risks for banks would be subject to some alternative approach; the coverage of the existing swaps-related rules must be broadened. The broad set of hedging products should thus be broken into two subsets: the "designated" products and "non-designated" products. "Designated" products would be handled by the capital adequacy system created by the BIS Accord; as regulators periodically modify the classifications and weights to take into account financial products which have been introduced or become more popular, the products covered will change from time to time. "Non-designated" products would be handled by the alternative approach.

\section{B. The Complexity of Evaluating An Incremental Solution}

Having identified the scope of the most urgently needed change, this Article concludes by briefly analyzing one prospective mechanism for dealing with the credit risk posed by non-designated products in a manner which avoids international public goods problems. The mechanism is swap insurance. ${ }^{266}$

266 There are many other ways of dealing with the non-designated products at the international level. Cf. supra notes 110 and 173 (concerning application of judgment in determining capital adequacy of individual banks). A few of the possible categories of solutions are listed below:

(1) Prohibition. Regulators can simply prohibit commercial banks and their affiliates from dealing with non-designated products in any way which would way create credit risks for those banks or bank affiliates. While this approach would solve the mispricing problem, it does so in a Procrustean fashion. The primary evaluative issue with this approach, as with any regulatory system which prohibits new innovations until approved by a regulatory agency, is balancing the benefits of the regulation against the curtailment of innovation. $C f$. $\mathrm{H}$. GRABOWSKI, DRUG Regulation and InNovation: Empirical Evidence and Policy Options 75 (1976) (concluding that prohibitory regulation of the drug industry in the United States by the FDA has had adverse effects on innovation); Whittaker, supra note 57 , at 11 (describing disadvantages to prohibiting bank participation in swap market); supra note 146 (difficulties in estimating benefits of product innovation).

(2) Minimization of Credit Exposure. Regulators could limit the amount of credit exposure that banks have on non-designated products. They could, for instance, set out the maximum relative amount of risk exposure a bank can have on these products at any one time. Alternatively, they could require that there be a mark-to-market mechanism which operates at regular intervals during the life of the non-designated product; under this scheme, the parties would regularly exchange payments reflecting changes in the nondesignated product's value arising from fluctuations in 
Although a system of swap insurance seems to avoid many of the

interest rates, exchange rates, commodity prices, or other market prices. Cf. When the Swap Meets the Option, Euromoney, Apr. 1989 (supplement), at 26, 32 (describing Manufacturers Hanover's periodic mark-to-market system).

(3) Risk-sensitive Deposit Insurance. If banks worldwide were required to pay deposit insurance premiums corresponding to the risks they assumed (including those as to their non-designated products), the banks themselves would be forced to "internalize" the social costs of failure. Banks would in effect pay for costs they inflict on society. Despite its appeal, a deposit insurance scheme with risk-sensitive premiums has not yet proven possible to implement in the United States; moreover, losses in a variety of federal insurance programs outside of the savings and loan context suggest the difficulties in operating such a system. See, e.g., Hershey \& Labaton, U.S. Fund Insuring Home Mortages Hit by Big Losses, N.Y. Times, June 21, 1989, at 1, col. 6 (reporting large losses by the main Federal Housing Administration fund which insures American home mortgages); Ingersoll, Farm Fiasco: Crop-Insurance Fraud and Bungling Cost U.S. Taxpayers Billions, Wall St. J., May 15, 1989, at Al, col. 6 (reporting losses by the Federal Crop Insurance Corporation which insures farmers against natural disasters); cf. suipra note 95 (concerning FIRREA requirement that the Secretary of the Treasury study variable rate deposit insurance). Any sort of risk-sensitive international deposit insurance scheme is likely to be even more difficult to implement and operate. See, e.g., Dean, Conservative Versus Liberal Regulation of International Banking, J. WORLd Trade, Feb. 1989, at 5, 11 (stating that international deposit insurance proposals "have never got off the ground").

(4) Credit Enhancement Mechanisms. Regulators could require that banks eliminate the credit risks of their non-designated products through collateral or third party arrangements. One way of doing so is the insurance proposal set out in the text. A variety of other ways are possible. For instance, regulators could require banks to obtain appropriate collateral from its customers as to all non-designated products. The costs of operating such a mechanism can be high and there are a number of bankruptcy and other legal obstacles which limit the usefulness of this approach. See Henderson, supra note 22, at 388-89; Note, Legal Doctrines Restricting the Secondary Market in Interest Rate Swaps, 26 Colum. J. Transnat'l L. 313, 323-24 (1988); Willoughby, Swap Flop, Forbes, Oct. 7, 1985, at 65 . Instead of requiring banks to obtain collateral, bank regulators could require that swaps be traded on an exchange so that the exchange's clearinghouse arrangements would, unless they were to also fail, provide the bank some protection against credit risks. This sort of scheme would be likely to dampen financial innovation. See, e.g., Zusy, Swaps Tradability, in The 1987 London Swaps SEMINAR, supra note 26, at 34-41 (transcript of address and copy of document entitled "Swaps Clearing House") (discussing advantages and disadvantages of various swaps clearing arrangements); $c f$. CFTC Swaps Policy Statement, supra note 87, at 30,696 (stating that the safe harbor from Commodity Futures Trading Commission regulation is limited to swap transactions which are, among other things, "not supported by the credit of a clearing organization and that are not primarily or routinely supported by a mark-to-market margin and variation settlement system designed to eliminate individualized credit risk"). 
pitfalls inherent in the BIS Accord's approach, the suggestion here is not that swap insurance is necessarily a feasible or desirable mechanism for regulating non-designated products. Instead, we analyze this highly incremental mechanism - a mechanism involving no new governmental or private institutions, no governmental expenditures or guarantees, and little international coordination - to illustrate the complexities of any solution. The difficulties involved in evaluating a mechanism as incremental as this suggests that a systematic review of how the capital adequacy system could be modified to accommodate the process of financial innovation must begin immediately.

\section{Specification and Swap Insurance: Surrogate Regulation as a Safety Valve}

Under a swap insurance program, the swap dealer would be required to obtain insurance which would fully protect it against loss on non-designated products by reason of its customer's default. A dealer would not be permitted to enter into a non-designated swap without such insurance; no capital (or minimal capital) would be required as to such swaps. Dealers would be permitted to obtain such insurance from any insurer or combination of insurers as long as each such insurer is not an affiliate of the dealer and the insurer meets certain objective standards of creditworthiness. To minimize disruption, existing non-designated products would be exempt from this system. Thus, the swap insurance requirement could be limited in its applicability to transactions involving non-designated products which are entered into subsequent to adoption of the mechanism. As a result of the natural aging process, all non-designated products will eventually be subject to the swap insurance scheme.

The nature of the coverage and the creditworthiness of the eligible insurers aside, each bank and insurer would have the freedom to negotiate the terms of its insurance arrangements. They could agree on whatever premium levels and whatever procedures for insuring particular swaps they wanted. Being self-sustaining entities, insurers would seek to match their premiums to the probabilistic estimates of loss. ${ }^{267}$ The premiums would presumably reflect, among other

Cf., e.g., OCC Capital Guidelines, supra note 31 , at 4172 (concerning decision not to give preferential risk weights to municipal revenue bonds supported by financial guaranty insurance); $i d$. at 4183 (excluding from capital adequacy requirements those swaps traded on exchanges and subject to daily margin requirements).

267 See, e.g., S. D'Arcy \& N. Doherty, The Financial Theory of Pricing Property-Liability InSURANCE CoNTRAGTs 86 (1988) (although advocating a more sophisticated method of determining insurance premiums, acknowledging that the 
things, the inherent credit risk characteristics of a particular type of swap as well as the creditworthiness of the counterparty. If a bank were to enter into a particularly risky swap, an insurer would presumably insist on a higher fee. Banks will have the incentive not to engage in too many risky swaps.

At first glance, the swap insurance proposal fulfills the basic objective of the BIS Accord of minimizing the destabilizing effects of credit risk assumed by banks in a manner which does not give rise to international collective action difficulties. Under the swap insurance proposal the BIS Accord's capital adequacy approach would continue to operate in the usual fashion with designated products, products which still will account for the bulk of the swap and related markets. However, with respect to non-designated products, banks must take out swap insurance. Having taken out swap insurance, the bank would be assured that upon any default it would receive an amount from the insurance company which would make it whole.

The insurance scheme would directly prevent a default by a bank customer from threatening the bank's stability, a goal capital adequacy requirements accomplish only indirectly. The swap insurance requirement would apply to banks in all countries; absent government intervention as to such insurance, the insurance premiums paid by banks would correspond to the risks taken on the designated products. Regulators would not be able to "cheat." Overall, the system of dealing with the credit risks posed by swaps and related products is one of government regulation supplemented by surrogate regulation.

In order for the insurance scheme to actually insulate the bank from credit risks of its hedging products, two conditions must hold. First, the insurance policy must provide compensation to the dealer in an amount which is roughly equal to the amount of damages suffered as a result of the default. Second, the insurer itself must not default on its obligation to the bank.

To fulfill the first condition, the bank must be insured as to the mark-to-market value of the swap. If its customer were to default on its swap obligations at a time when the interest rate, exchange rate, commodity price, or other fluctuations had moved against the counterparty, the bank would avoid any loss if it received an amount equal to the mark-to-market value. ${ }^{268}$

traditional insurance pricing approach projects expected losses and expense, and charges a premium that allows a certain profit margin).

268 See supra notes 64-65 and accompanying text. In the event that reliable 
The more difficult condition to satisfy is that of making sure that the insurer itself will not default on its obligations on the insurance policy. To simply rely on government regulation of insurers to accomplish this would make little sense. The net result would be simply to shift the regulatory focus from banks to insurers. The kinds of problems which prevent effective regulation of banks would also prevent effective regulation of insurers. The frame of reference would change but many of the problems would remain. After all, financial guarantors and other insurance companies can also become insolvent and their failure would have troubling social effects as well. ${ }^{269}$

The circularity can be broken by introducing market factors into the analysis. By requiring that the financial guarantors carry credit ratings of the requisite grade, the risk of default can be reduced. Bank regulators can choose how much of a risk of default on the insurance obligation they are willing to accept. For instance, by insisting that all eligible insurers receive the highest credit rating from an internationally recognized and officially approved rating agency, ${ }^{270}$ regulators would assure a high probability that the insur-

mark-to-market values are unavailable, appropriate formulas for estimating damages could be agreed upon by the parties.

269 See, e.g., Deposit Insurance Reform and Related Supervisory Issues: Hearings Before the Senate Comm. on Banking, Housing, and Urban Affairs, Pt. II, 99th Cong., 2d Sess. 16 (1986); Lappen, Guarantees with Nothing Behind Them, Forbes, July 24, 1989, at 41; Schifrin, What's a Guarantee Worth?, ForBes, July 24, 1989, at 88; see also infra note 312 (concerning new New York statute pertaining to financial guaranty insurers).

270 Ratings agencies typically rate not only the issuer itself but also each separate debt instrument. See Keslar, The Power of Ratings in the Marketplace, CoRP. Fin., July 1985, at 45 . For convenience, this Article will ignore this distinction.

In the United States, obtaining ratings from the two most prominent ratings agencies is a matter of course. These ratings agencies, Moody's Investor Services and Standard \& Poor's, dominate both the United States and European capital markets. See Dickins, The Rating Game, CoRP. Fin., Feb. 1989, at 44. For a description of these as well as two other United States ratings agencies, see D. Hawkins, B. Brown, \& W. Campbell, Rating Industrial Bonds 17-19 (1983) [hereinafter HaWkins STUdY].

Market recognition of the ratings is significant. As Standard \& Poor's has noted:

Credit ratings are of value only if they are credible. Credibility arises from the objectivity of the rater and his independence of the issuer's business. The investor is willing to accept the rater's judgment only where such credibility exists. When enough investors are willing to accept the judgment of a particular rater, that rater gains recognition as a rating agency.

Credibility is fragile. [Standard \& Poor's] operates with no governmental mandate, subpoena powers, or any other official authority. It simply has a right, as part of the media, to express its opinions in the form of letter symbols. 
ance company will be able to pay off on a claim. Even within the triple-A category there are gradations of risk. To guard against the possibility that the credit agency is wrong, regulators could insist on a "double triple," or triple-A ratings from two such agencies. ${ }^{271}$ Both United States Treasury securities (with debt backed by the "full faith and credit" of the United States) and various governmental agency securities (with debt which do not carry such an explicit governmental assurance) carry triple-A ratings. United States Treasury securities are generally considered somewhat less risky from a credit standpoint and thus trade at somewhat lower yields. ${ }^{272}$ Regulators could, therefore, insist that implicit market valuations of default risk of instruments insured by eligible insurers not exceed prescribed levels.

As a working model, assume that an insurer would be eligible if two conditions were met. First, insurers must carry a "double triple." Second, if an insurer insures not only swaps but also publicly traded bonds, those bonds must trade at yields which are consistent with prescribed levels of market confidence in the creditworthiness of the insurer. ${ }^{273}$ In the event that the insurer on a swap declines in creditworthiness subsequent to commencement of the swap, the bank would be required to replace the insurer with an eligible insurer.

Standard \& Poor's, Debt Ratings Criteria: Finangial Institutions 3 (1988) [hereinafter $S$ \& P RATING CRITERIA].

271 Ratings by different agencies may be markedly different. See Comparing the Comparers, EuromoneY, July 1989, at 15 (comparing the credit ratings given to the world's top banks by Moody's, Standard \& Poor's, and IBCA, a London based bank rating agency); infra note 293. Requiring the highest rating from two agencies would, therefore, serve to further limit the number of eligible insurers. Cf. Hsueh \& Kidwell, Bond Ratings: Are Two Better Than One?, FIN. MNGr., Spring 1988, at 46 (discussing effect of "split ratings" and why borrowers obtain more than one credit rating for their debt).

272 See Zigas, There Are More Ways Than Ever to Get Uncle Sam Behind You, Bus. WK., Dec. 26, 1988/Jan. 2, 1989, at 160.

273 Specification of the prescribed level would have to go beyond simply stating that the yield on bonds insured by a particular company cannot exceed a certain amount higher than the yield on bonds of comparable maturity issued by the U.S. Treasury. See F. Fabozzi \& T. Fabozzi, Bond Markets, Analysis and Strategies 124-25 (1989) (discussing how the quality yield spread between bonds of different credit ratings varies over the interest rate cycle); Paschal, Insurers Urge SEC to Clarify or Delete Credit Enhancement in Disclosure Rules, BOND BuYER, Jan. 12, 1989, at 1 (discussing the importance of issuer's creditworthiness). 


\section{Identifying Some Questions and Moving Toward Some Answers}

The feasibility and desirability of the swap insurance mechanism depends on satisfaction of a number of conditions. ${ }^{274}$ Three of these are particularly important. First, there must be insurers willing to insure against default on such complex instruments. Second, the likelihood of insurer default must be acceptably low. Third, the direct and indirect costs of the insurance must bear a reasonable relationship to the risks assumed by the financial guarantors.

\section{a. Existence of Insurers}

First introduced in the early 1970 s for municipal bonds, financial guaranty insurance has moved beyond its municipal bond origins to include corporate bonds, commercial paper, unit investment trusts, and a host of other financial instruments. ${ }^{275}$ As of the end of 1987 , the total amount of principal and interest insured by the four largest United States financial guaranty insurers exceeded $\$ 215$ billion. ${ }^{276}$ Under these arrangements, insurers typically undertake to guarantee "irrevocably and unconditionally" the payment of principal and interest on a timely basis. ${ }^{277}$ Established ratings agencies have given virtually all of these insurers the highest possible credit ratings. ${ }^{278}$ Because of the creditworthiness of the insurers and the

274 Cf. Abraham, supra note 35, at 945-49 (describing how most types of insurance can perform their functions effectively only under very special conditions of uncertainty).

275 See Miegs, Financial Guaranty Insurance and Investor Confidence, CREDIT Decisions, June 29, 1987, at 1; Milligan, The Pioneer of Corporate Debt Guarantees, INSTTTUTIONAL INVESTOR, Apr. 1988, at 197.

276 See Ratings and Statistical Guide, Standard \& Poor's CredrTWeek, Oct. 17, 1988 (Bond Insurance CreditReview supplement), at 24 [hereinafter SESP Ratings Guide].

277 See Western Financial Auto Loans 2, Inc., Prospectus (Oct. 18, 1988); Meigs, supra note 275 , at 1 .

Although financial guaranty insurance is the best analogy to the proposed swap insurance system, there are other types of insurance to which an analogy could be drawn. See, e.g., Gorman, New Credibility for the Corporate Bill Collector, N.Y. Times, May 7,1989 , at C15, col. 1 (noting the availability of insurance to protect against losses on accounts receivable); infra note 307 (concerning Delta Government Options).

278 See Credit Analyses, Standard \& Poor's CreditWeek, Oct. 17, 1988 (Bond Insurance CreditReview Supplement), at 11-23 (reporting triple-A ratings for all municipal bond insurers considered); see also AMBAC INDEMNITY CoRPORATION, 1987 ANNUAL REPORT 7 (1988) (noting that the four major municipal bond insurance companies all have triple-A rated claims-paying ability, a fact which illustrates the "fundamental soundness and strength of the industry as a whole"). But see Subcommittee on Financial Guarantee Instrumentation of the Committee on 
unconditional and irrevocable nature of the guarantee, the investor is significantly insulated from the credit risk associated with the issuer.

In a swap insurance scheme, the complexity of the individual instruments themselves - a factor making effective government regulation difficult - is unlikely to be a problem for private insurers. The personnel of these financial guaranty insurers are highly qualified and have experience in the structuring of complex financial products. $^{279}$ One financial guaranty insurer had a president who was responsible for global management of swaps, a senior vice president who had specialized in swaps, caps, and options, and a third senior vice president who was responsible for making interest rate swaps accessible to the real estate market. ${ }^{280}$ To the extent that a financial guaranty insurer is held by a bank or group of banks, the owners can be a source of financial expertise and management support. ${ }^{281}$

Furthermore, financial guaranty insurers have already insured the showpiece examples of the technical prowess of rocket scientists. ${ }^{282}$ For example, in the course of a single year, one company

Developments in Business Financing, NAIC Model Act on Financial Guaranty Insurance: A Commentary, 43 Bus. LAw. 717, 717 (1988) (expressing concern about the inadequate regulation of financial guarantors); Peers, Municipal Bond Insurance Gets Cheaper, Wall St. J., March 1, 1989, at C1, col. 2 (noting that municipal bond insurance is largely untested).

Financial guaranty insurance is provided by both "monoline" insurance companies, which insure only third-party debt, and "multiline" insurance companies which also offer more traditional commercial and property/casualty insurance products in addition tô debt insurance. See, e.g., Rating Methodology, STandard \& PoOR's CREDITWEEK, Oct. 17, 1988 (Bond Insurance CreditReview Supplement), at 6.

279 See, e.g., Singer, Bond Insurer Cited for High Productivity, N.Y. Times, June 18, 1989 , $\S 22$, at 12 , col. 3 (reporting that three out of every four employees of the leading municipal bond insurer in the United States hold an advanced degree and that all have had years of experience in business, government, and finance).

280 See Capital Markets Assurance Corporation, Management (undated advertisement) (on file with the University of Pennsylvania Law Review).

281 See Financial Guaranty Insurance Company, Profile and Programs: FGIC 3 (1988). This is a mixed blessing from a regulatory standpoint; the bank ownership can complicate analysis of the swap insurance scheme considerably. $C f$. e.g., Wall St. J., June 12, 1989, § 2, at 5, col. I (stating that a financial guaranty insurer was expected to complain to the Federal Reserve Board that a municipal bond insurer owned by a bank holding company double counts the unit's capital for banking purposes); cf. also R. LrTaN, What Should Banks Do? 99-143 (1987) (describing risks of removing financial product-line restrictions on banks); infra note 312 (discussing U.S. West acquisition of corporate bond insurer).

282 See Financial Security Assurance Inc., A Guarantee of Quality in Corporate Debt Securities 6-11 (1989) [hereinafter FSA Report] (discussing Financial Security Assurance's involvement in a public issue in which financial assets were sold to reduce leveraged buyout debt); Moody's Investors Service, Special 
insured bonds secured by a pool of retail installment sales contracts secured by new and used automobiles, ${ }^{283}$ as well as bonds secured by over 74,000 home mortgages averaging about $\$ 23,000$ each. ${ }^{284}$ In order to evaluate properly the risks involved in these kinds of securities, complex computer modeling of cash flows, sophisticated "worst case" simulations and careful statistical sampling techniques have all been used. ${ }^{285}$

Even more convincing than the characteristics of the financial guaranty insurance market is the fact that swap insurance of sorts already exists. ${ }^{286}$ The World Bank and the Deutsche Bank have in place a program whereby the Deutsche Bank would insure up to $\$ 1$ billion of the World Bank's currency swaps with European counterparties with maturities of up to ten years. ${ }^{287}$ Pursuant to this arrangement, in the event of a default, Deutsche Bank would have the option either to enter into a financially equivalent replacement swap directly with the World Bank or to pay the World Bank the market value of the swap. Because of this arrangement, the World Bank can enter into swaps with counterparties whose credit stand-

Report: FSA - Financial Security Assurance Inc. 5-10 (1987); $c f$. SESP Ratings Guide, supra note 276, at 21 (noting insurer's "emphasis on unique and innovative structures"); US Mortgage-Backed Securities: The True Home of the Rocket Scientist, INT'L FIN. REv., Aug. 8, 1987, at 2600 (discussing complexity of mortgage-backed instruments).

283 See Western Financial Auto Loans 2, Inc., supra note 277.

284 See Moody's Investors Service, supra note 282, at 6.

285 Cf. Monroe, Moody's, SE'P are Thrust Into New Role, Wall St. J., Sept. 16, 1986, $\S 1$, at 6 , col. 1 (stating that the complexity of structured financings makes the rating process crucial and that professional investors often cannot do their own analysis, as they do customarily with traditional debt offerings).

286 Under the former program between the World Bank and Aetna, Aetna in effect insured five swaps. See International Capital Markets: The World Bank Decides on Das Deutsche-Swap, Int'L Fin. Rev., July 23, 1988, at 2383; see also The World Bank, SwaP Insurance Program - General INFORMation, reprinted in INTEREST Rate and Currency Swaps 1987, at 47-52 (1987) (discussing the general aspects of the World Bank's swap insurance program); Brenner, Aetna Pioneers Insurer Role in Swap Guarantees, AM. BANker, Mar. 17, 1986, at 1 (discussing Aetna's approval of "about 100 corporations for swaps" with the World Bank).

Protection against the default of the bank's customer is also possible through the purchase of a standby letter of credit. See Adams \& Peck, The Federal Home Loan Banks and the Home Finance System, 43 Bus. LAw. 833, 851 (May 1988).

287 See When the Swap Meets the Option, Euromoney, Apr. 1989 (supplement), at 26, 27; World Bank, Press Release No. 89/F9 (July 28, 1988); cf., e.g., Cooper, Swaps An Even Bigger Black Box, Euromoney, June 1989 (supplement), at 75 (describing how one investment house is "currently working on a number of potential [swap] deals with investors involving credit enhancement via mechanisms including insurance company guarantees"). 
ings would otherwise disqualify them due to the World Bank's stringent policies. ${ }^{288}$

Deutsche Bank is not alone in offering swap insurance. For instance, Capital Markets Assurance Corporation ("CapMac"), a financial guarantor with a triple-A rating from Standard \& Poor's, has also begun offering swap insurance. Under its plan, a party can purchase a surety bond from CapMac which covers all or a specified part of the losses on default of the other party to the swap. ${ }^{289}$ Under the CapMac plan, swap dealers can purchase surety bonds covering swaps and related instruments with counterparties who have a triple$B$ rating. ${ }^{290}$

If the proposed swap insurance requirement as to non-designated products is adopted, the demand for swap insurance will increase dramatically. The existence of a nascent swaps insurance industry even in the absence of such a regulatory requirement and the existence of a large and sophisticated financial guaranty industry strongly suggest that there would be some swap insurers of the requisite creditworthiness and sophistication.

The fact there might be some qualifying swap insurers, however, only suggests that some swap insurance would be available. Before a swap insurance requirement can be adopted, there must be some assurance that the contemplated swap insurance market will be deep enough to handle all of the credit risks to be assumed. ${ }^{291}$ After all, the use of extremely stringent creditworthiness standards and the complexity involved in assessing the risks of non-plain-vanilla hedging instruments mean that the number of potential swap insurers may be quite low. If regulators elect to adopt the swap insurance supplement to the capital adequacy system despite a capacity prob-

288 See World Bank, supra note 287 (stating that without the new swap arrangements, the World Bank could only swap with corporations or public entities rated triple-A); see also Simonian, Deutsche Bank Agrees on Swap Deal, FrN. Times, July 29,1988 , at 23, col. 1 (stating that "[u]nder its existing rules, the World Bank can only enter deals with triple A rated counterparties").

289 See Capital Markets Assurance Corp., Swap Insurance (undated); see also Swap Default Insurance Cost Revealed, Swaps Monitor, May 29, 1989, at 4 (describing CapMac's system of pricing swap insurance).

290 See Swap Default Insurance Cost Revealed, supra note 289, at 4 (discussing the cost of insuring an interest rate swap against default by a triple-B party). As of May 1989, CapMac had not yet written any swap default insurance. See id.

291 For a discussion of the problems of availability in other insurance areas, see Abraham, supra note 35, at 943-44 (discussing the difficulty of obtaining environmental liability insurance); Clarke, Warren-Boulton, Smith \& Simon, Sources of the Crisis in Liability Insurance: An Economic Analysis, 5 YALE J. ON REg. 367, 367 (1988) (discussing the "unaffordability and unavailability" of property-casualty insurance). 
lem, the regulators would be able to ameliorate the capacity problem by increasing the number of "designated products." Since the swap insurance scheme is only applicable as to non-designated products, less pressure would be put on the capacity of the swaps industry. By carefully modulating the mix of designated and non-designated products, regulators can ensure that the safety valve of swap insurance be used only for the most egregious cases of regulatory mispricing.

In sum, it is highly likely that there will be swap insurers of the requisite creditworthiness and sophistication. However, absent empirical analyses of both potential entrants and the relative importance of products in the designated and non-designated product classes, it is impossible to determine whether there would be suffcient capacity to handle all of the non-designated product credit risk. To the extent that there is a capacity problem, regulators can ameliorate the problem by increasing the number of products in the designated products category.

\section{b. Insurer Default}

The proposed system depends on each financial guaranty insurer being able and willing to meet its obligations to its bank customer upon default by the swap counterparty. ${ }^{292}$ As discussed earlier, under the working model, a qualifying insurer would have to

292 A financial guarantor, even if solvent, may of course seek to avoid paying a claim with respect to a swap default on various technical grounds. This "weaseling out" problem has been analyzed in the context of the financial guaranty insurance generally. Given the ratings assigned to insured bonds, ratings agencies have apparently deemed this to be unlikely. The market, however, is not quite as confident; some believe that this doubt contributes to triple-A insured bonds typically trading at "double-A" yields. See infra note 302.

Close analysis of possible defenses in the posited swap insurance system will be necessary. A bank which has actively participated in the procurement of swap insurance for its own benefit may not necessarily stand on the same footing relative to a defending insurance company as the beneficiary of bond insurance which had been arranged by the issuer itself. For discussion of these issues in the general financial guaranty context, see United States Securities and Exchange Commission, Report on the Financial Guarantee Market: The Use of the Exemption in Section 3(a)(2) of the Securities Act of 1933 for Securities Guaranteed by Banks and the Use of Insurance Policies to Guarantee Debt Securities 37-38 (1987) [hereinafter SEC RePORT]; Letter from Robert A. Meyer, Bond Investors Guaranty, to Lynette Carter, Office of the Comptroller of the Currency, William H. Wiles, Board of Governors of the Federal Reserve System, and Hoyle L. Robinson, Federal Deposit Insurance Corporation (May 13, 1988) (describing limitations on defenses available to such insurers); Letter from David $\mathrm{H}$. Elliott, Association of Financial Guarantor Insurors, to Lynette Carter, Office of the Comptroller of the Currency, William H. Wiles, Board of Governors of the Federal 
meet a "double triple"293 credit rating standard as well as carry market risk premia which do not exceed specified levels. A "double triple" institution presumably has a default risk that is equal to or lower than that of comparable institutions with a split rating. The market risk premia requirement may help screen out entities that have suffered deteriorations in creditworthiness not yet reflected by downgradings in their credit ratings. ${ }^{294}$ This standard is more stringent than a simple triple-A standard. Evidence that even a simple triple-A standard is stringent would thus be quite comforting.

A simple triple-A standard is quite stringent. Ratings agencies do not assign triple-A ratings lightly. As of February 1988, less than two percent of the senior debt of United States industrial companies was rated triple-A by Standard \& Poor's. ${ }^{295}$ As of November 1988, only twelve American industrial companies were assigned a triple-A rating by Standard \& Poor's. ${ }^{296}$

The creditworthiness of an insurer could of course decline. Luckily, one of the leading sources of rapid declines in creditworthiness in recent years - the financial restructuring which has created socalled "event risk" 297 - is less likely to cause such problems for finan-

Reserve System, and Hoyle L. Robinson, Federal Deposit Insurance Corporation (May 10, 1988) (same).

293 Ratings agencies can differ on their ratings. See supra note 271 . The differences can be accentuated when complicated financial instruments are involved. Cf. Dickins, The Rating Game, CoRP. Fin., Feb. 1989, at 46 (stating that "as corporate structures become more complex, agencies are more likely to rank borrowers differently"); Morlgage Funding Corp gets the Moody's blues, CoRP. Fin., Sept. 1988, at 5 (discussing how two rating agencies gave different ratings to a company that issued more than $\$ 300$ million of floating rate notes).

294 Some observers believe that ratings agencies lag behind events in downgrading issuers. See, e.g., American Money-Centre Banks: A Pile of Junk, Economist, Feb. 6, 1988, at 82 ("When Standard \& Poor's . . downgraded the debts of some of America's largest banks on February Ist, it was stating the obvious. Investors had been downgrading those securities themselves for months."); Herman, Downgrading the Credit Rating Services, Wall St. J., June 23, 1989, at C1, col. 2 (quoting an officer at an investment counselling firm as saying that credit ratings "lag behind current events in many instances").

295 Standard \& Poor's Corporation, Comments on the Nature of the Market for High Yield Bonds, reprinted in United States General Accounting Office, High Yield Bonds: Nature of the Market and Effect on Federally InSURED InSTrTUTIONS 181 (1988). Similarly, Moody's gave its triple-A rating to only $\$ 7.90$ billion of the $\$ 113.09$ billion new U.S. corporate debt it rated. See Market Statislics 1988: United States, Moody's Bond SuRv., Jan. 23, 1988, § 2, at 7697.

296 See Sheeline, The Straight-A Club, Fortune, Nov. 21, 1988, at 9.

297 Standard \& Poor's defines "event risk" as "the potential for a sudden and dramatic decline in credit quality resulting from a large stock repurchase or dividend payment by the obligor, the obligor's acquisition by another entity, or other restructurings that remove assets from or add liabilities to the obligor." Hessol \& 
cial guarantors. This is because the nature of the creditworthiness issue in the typical corporation is distinguishable from that of a financed guaranty insurer. With the typical corporation, creditworthiness is not a goal in itself, but is instead one of the tools to maximize shareholder value. Thus a triple-A credit rating, far from being a goal of management, might even be a sign that the capital structure of the firm is not optimal. ${ }^{298}$ The situation is quite different with a financial guaranty insurer because "[a]ll a financial guarantor sells is [its] triple-A."299 Because the loss of a triple-A rating would ravage the value of the financial guaranty insurer itself, both current and would-be management will have unusually strong incentives to avoid engaging in any restructuring which would could result in the loss of the triple-A rating. ${ }^{300}$

Finally, as an empirical matter, obligations bearing high credit ratings tend to have low default rates. Of 52 corporate issuers which defaulted from 1972 to 1984 , only one was rated as high as triple-B, the lowest category within the "investment grade" class. ${ }^{301}$ An analysis of all corporate straight debt in the period 1970 through 1986 found that not a single issue carried either a triple-A rating or a double-A rating from Standard \& Poor's one year before default. ${ }^{302}$

Samson, Event Risk Covenant Rankings, Standard \& Poor's CredirWeek, July 24, 1989, at 1. For a discussion of the "event risk" issue, see European bond markets: Main events, ECoNOMIST, July 22, 1989, at 71; Global Outlook 1989: Overview, Moody's Bond Surv., Jan. 23, 1989, § 2, at 7660, 7661.

In July 1989, Standard \& Poor's began explicitly ranking the protection of corporate debt obligations against event risk. See Hessol \& Samson, supra, at 1.

298 See, e.g., Standard \& Poor's Corporation, supra note 295, at 181, 182 \& 187; Stillit, The Perfect Capital Structure, Corp. Fin., Nov. 1988, at 54, 59.

299 See Farrell, The Risky Business of Insuring Muni Debt, Bus. Wk., Apr. 27, 1987, at 96,97 (quoting the executive vice president of a financial guarantor firm after its ratings had dropped); cf. MBIA INC., ANNuAL REPort on Form 10-K, at 14 (1989) (noting that an insurer's "ability to compete with other financial guarantors would be materially adversely affected by any reduction in its ratings").

300 Cf. Mebus \& Levin, Property/casualty insurers' low event risk, Standard \& Poor's CreditWeek, Apr. 24, 1989, at 20 (discussing the low event risk of property and casualty insurance companies).

301 See Keslar, supra note 270, at 46; cf. STandard \& Poor's Corporation, supra note 295, at 185 (for the period 1977 through 1987, with one exception, all defaults on rated public debt were confined to the speculative grade sector).

302 See Altman, Measuring Corporate Bond Mortality and Performance (Feb. 1988), reprinted in U.S. General Accounting Office, High Yield Bonds: Nature of THE MaRKet AND EFFEct ON FEDERally INSUREd INSTITUTIONS 155, 158 (1988); $c$. Moody's Investors Services, Historical Default Rates of Corporate Bond IssuERs 1970-1988, at 7 (July 1989) (stating that from 1970 to 1988, every defaulting issuer with a Moody's rating carried a simple A or lower rating).

Double-A bond data is relevant because insured bonds typically trade at doubleA interest levels. See Farrell, supra note 299, at 96- 97 ("Issues backed by an AAA 
Only one to two percent of bonds originally issued in 1970 with ratings of double-A or triple-A from Moody's ended up defaulting in the nineteen subsequent years. ${ }^{303}$

In sum, under normal economic conditions, it is highly unlikely that a qualifying swap insurer will default on its obligations. The more difficult issue is posed by concerns over whether such insurers would in fact be able and willing to protect their customers in the event of a world-wide financial cataclysm. ${ }^{304}$ In evaluating this

insurer usually sell at the higher yields of an AA bond.") Market investors do not quite believe that insured bonds really deliver triple-A quality. Part of this skepticism stems from a concern that bond insurers might somehow weasel out of their obligations. See Celarier, Are the Risks Covered, U.S. BANkER, Nov. 1987, at 72 (quoting the officer of a financial guarantor as saying that investors suspect "someplace there's some fine print" that will allow the financial guarantor to "weasel out"); Rudnitsky, What's in a Rating?, Forbes, Sept. 12, 1983, at 41 ("Even MBIA's Miralia admits that 'most insured are selling as double-A and sometimes as cheap double-A.' The market is telling you that turning triple-B insured into a triple-A may not be the bargain it seems to be."); supra note 292.

303 See Moody's Investors Services, supra note 302, at 22.

Only "anecdotal" statistics are used here to illustrate the low default risk as to high quality bonds; more sophisticated statistics are nonetheless consistent with the anecdotal evidence. See, e.g., Altman, Measuring Corporate Bond Mortality and Performance, 44 J. Fin. 909, 913 (1989) (noting that, based on data for the period 1971-1987, "AAA-rated debt had a zero mortality rate for the first five years after issuance and then only 0.13 percent from six to ten years (due to Texaco's 1987 bond default)"). The current dispute in the junk bond market over the proper methodology for evaluating historical bond default rates have not undermined the general notion that bonds with Triple-A ratings are relatively unlikely to end up in default. Cf. SEC REPORT, supra note 292, at 54 ("The apparent accuracy of the ratings agencies in designating a AAA or "prime" rating has made the AAA rating an attractive and generally reliable indicator of credit risk for the investor."). For a sense of the current controversy over the proper methodology for analyzing bond defaults, see Altman, supra; Asquith, Mullins, \& Wolff, Original Issue High Yield Bonds: Aging Analyses of Defaults, Exchanges, and Calls, 44 J. Fin. 923 (1989); Junk Bond Defaults at 11.2\%, N.Y. Times, Aug. 16, 1989, at D12, col. 5; Ricks, Even 'Soft Landing' May Jolt 1 of 8 Junk Bonds, Wall St. J., July 12, 1989, at C1, col. 3.

The 1983 default on bonds to finance plants 4 and 5 of the Washington Public Power System was the largest in the history of the tax-exempt muncipal bond market. Standard \& Poor's rated the bonds " $A$ " at the time of their issuance. For background on this fascinating story, see The Bonneville Power Administration [BPA] and Washington Public Power Supply System [WPPSS]: Oversight Hearing before the Subcomm. on Mining, Forest Management, and Bonneville Power Administration of the House Comm. on Interior and Insular Affairs, Pt. I, 98th Cong., 2d Sess. (1984); Bernstein, A Nuclear Fiasco Shakes the Bond Market, Fortune, Feb. 22, 1982, at 100; Datta, Analysts Group May Examine Members' Roles in WPPSS Case, BOND BUYER, Oct. 28, 1988, at 1; Settlement on Default is Approved, N.Y. Times, Sept. 7, 1989, at D5, col. 3.

304 For analysis of default rates during the Great Depression, see W. Hickman, Corporate Bond QualtTy aND INVEstor EXPERIENCE (1958); Fitzpatrick \& Severiens, Hickman Revisited: The Case for Junk Bonds, J. Portrolio MGMT. 53 (1978). Michael Milken, of junk bond fame, first encountered Hickman's work in college. See 
aspect of the swap insurance scheme, the same kind of political judgment which went into determining how much capital was "adequate" will need to be made as to whether these risks are tolerable.

\section{c. Cost}

The costs associated with entering into appropriate insurance arrangements raise subtle issues. If the transaction costs in obtaining insurance coverage or the insurance premiums themselves are too high relative to the credit risks involved, the swap insurance scheme would serve to chill the market for non-designated products. A bank may decide not to bother offering the product and any private and social benefits associated with the new financial product ${ }^{305}$ would be lost. Instead of simply ensuring that banks engage in nondesignated products activity in a manner which does not create unacceptable risks for society, the insurance scheme would instead deprive society of the instruments themselves. If the insurance premiums are too low relative to the credit risks involved, the long-run viability of individual swap insurers would be threatened.

While the transaction costs involved in obtaining insurance coverage cannot be estimated with any certainty without empirical research, the likely circumstances in which such transactions costs will arise can be outlined. A swap dealer who anticipates doing a material amount of non-designated product business would likely want to first enter into a master agreement with each of the major swap insurers. This type of master agreement could cover the basic kinds of rights and obligations which would govern the relationship between the swap dealer and the swap insurer. Having established a network of master agreements, a swap dealer could limit negotiations with swap insurers as to the insurance coverage for a specific

C. Bruck, The Predators' Ball: The Junk-Bond Raiders and the Man Who STAKED Them 27-28 (1988).

One can argue that, by concentrating huge bank swap risks onto a relatively few number of insurers, the swap insurance scheme itself has the potential for increasing the chances of financial cataclysm. Several factors serve to mitigate this concern. First, swap insurance may represent only a small part of the business of the insurer; indeed, the credit rating and risk premium mechanism contemplated in the working model will tend to prevent insurers from becoming too dependent on any one sector. Second, the swap insurance scheme is supplementary to the capital adequacy approach established under the BIS Accord. Swap insurers only absorb the credit risk of non-designated products; the credit risks associated with designated products-the kinds of plain vanilla swaps which are predominant in the marketplace-are still absorbed by the banks themselves.

305 See supra note 146. 
swap transaction to the particulars of the counterparty and kind of swap involved. If a swap dealer accepts the quote given by a particular swap insurer, the two could then document that fact through an exchange of simple confirmations; the specific swap transaction would then be covered by the master agreement, modified by the pricing terms set out in the confirmation. ${ }^{306}$

While this master agreement system would involve far lower transactions costs than separate, fully-negotiated agreements for each particular swap transaction, the transactions costs may nevertheless still be too high in the judgment of a swap dealer. A swap dealer may not have the luxury of providing information as to specific counterparties and swaps to a series of swap insurers and then waiting for quotes before being able to make a commitment to the swap dealer's customer. A swap dealer would want to establish an arrangement which functions much like a credit card in the wallet of a consumer. A swap dealer would like to be able to simply place a swap on its account with the swap insurer of his choosing without having to obtain the prior consent of the swap insurer; under this arrangement, the types, amounts, and counterparties for whom this system would operate would be specified in the master agreement. While there is some precedent for this type of arrangement in the financial guaranty industry, ${ }^{307}$ the question of whether this type of arrangement will be widely available under the swaps industry scheme or permitted by ratings agencies or state insurance regulators will be an important one in determining the overall feasibility of such a scheme.

The level of insurance pricing will also play a critical role in determining the feasibility of the swaps insurance scheme. Two of the major obstacles to proper regulatory pricing under the BIS

306 Because of the relatively small size of most swaps, this master agreement approach would reduce transactions costs significantly. The average notional amount of interest rate swaps entered into in the first half of 1988 was $\$ 20$ million and that of currency swaps was $\$ 33$ million. AM. BANker, Dec. 8, 1988, at 3, col. 4 . This system would be analogous to the master agreement system in wide use for the documentation of swaps. See supra note 82.

307 See, e.g., Vanguard Money Market Reserves, Prospectus 10 (Mar. 31, 1988) (discussing procedures which were used by the former "Insured Portfolio" mutual fund in obtaining insurance against credit risk of money market instruments); Delta Government Options Corp., Prospectus 7-8, 14-15 \& 29 (Jan. 12, 1989) (discussing system for the trading of put and call options wherein the issuer is protected from default on the part of participants in the system by financial guaranty insurance); $c f$. Board of Trade v. SEC, 883 F.2d 939 (7th Cir. 1989) (vacating the SEC's temporary approval of clearing agency registration for Delta Government Options Corporation). 
Accord do not operate as to the swap insurance scheme. The mapping problem endemic to the classification-based BIS Accord's system should not occur; under the swap insurance scheme, pricing is agreed upon with a particular transaction in mind. Similarly, the kinds of regulatory lags arising from the necessity of renegotiating across countries under the BIS Accord's system should not occur; under the swap insurance scheme, only two parties are directly involved and they only need to decide the price as to the particular transaction.

The question of whether the insurance premium will bear a reasonable relationship to the credit risks of non-designated products will turn on whether the insurers would be able to evaluate those risks correctly and, if they do, whether they will elect to charge a reasonable premium. Although it is always possible that a swap insurer will misjudge the risks on a new financial product, the likely background of the relevant personnel suggests that this would not happen very often. ${ }^{308}$ As discussed earlier, financial guarantors have had extensive experience in dealing with complicated instruments. ${ }^{309}$ Furthermore, to the extent that risk information as to a particular non-designated product has not yet diffused into the marketplace, swap dealers may be somewhat more forthcoming with swap insurers than with government regulators. With swap insurers, there is no possibility that they will have to divulge sensitive information because of the Freedom of Information Act or similar laws. Moreover, to the extent that confidentiality is needed, financial institutions could ask for an appropriate non-disclosure agreement. Available evidence in analogous contexts suggests that confidentiality can be maintained. ${ }^{310}$ The primary concern here would be the willingness of banks to share information with insurers who may be affiliated with competitor institutions. ${ }^{311}$

The continuing ability of insurers to evaluate these complex

308 Moreover, the stringent creditworthiness requirements help assure that mistakes in one or more transactions would have to be disastrous before the ability of the financial guaranty insurer to meet its obligations is threatened.

309 See supra notes 280-86 and accompanying text.

310 Cf. Liu \& Moore, The Impact of Split Bond Ratings on Risk Premia, 22 Fin. Rev. $71,74 \& 83-84$ (1987) (providing statistical evidence consistent with the notion that confidential information collected by ratings agencies is kept out of the public domain).

311 Financial guaranty insurers need not be owned by or affiliated with banks or insurance companies. For instance, U.S. West Inc., the regional Bell telephone company serving the Rocky Mountain states, announced plans recently to acquire Financial Security Assurance Holdings Ltd., the largest insurer of corporate bonds. See Quint, Bond Insurer to be Bought by U.S. West, N.Y. Times, Oct. 5, 1989, at D1, col. 6. 
products can be monitored by the presence of the ratings agencies. $^{312}$ Ratings agencies will not assign a triple-A rating to an insurer which they believe lacks the basic capacity to evaluate risk. ${ }^{313}$ Ratings agencies are well-positioned to undertake this evaluative role. Ratings agencies have developed specific expertise with respect to complex new financial products and with respect to financial guaranty insurers. Indeed, rating agencies are familiar with both the legal and economic complexities of innovative securities (including swaps and over-the-counter options), and have themselves engaged in original empirical and legal analyses pertaining to new securities of the utmost complexity in an effort to determine their risk characteristics. ${ }^{314}$ Ratings criteria have, in fact, become blueprints for

312 One municipal bond analyst referred to state regulation of the municipal bond industry as a "joke" and said that "there's nothing wrong with the rating agencies having a strong influence on the business" and that he was "glad to see they're keeping them honest." Greenwald, Triple-A Ratings Expensive, Insurers Say, Bus. INs., Oct. 10, 1988, at 38 (quoting Jeffrey Noss, a Vice-President and Bond Analyst with the Bank of New York). This situation may be changing; in April 1989, New York State adopted statutory provisions pertaining specifically to financial guaranty insurers. See Laws of New York Ch. 48 (adding Article 69 to New York Insurance Law).

The ratings agencies charge for this regulation. "Observers conservatively estimate that the municipal bond insurance industry now spends about $\$ 20$ million annually for its ratings." Greenwald, supra. at 38.

313 See, e.g., Public Finance Department, Moody's Investors Service, Inc., Financial Guaranty Insurance Company: Update 3 (1988) ("Confidence in a bond insurer's underwriting standards and procedures is key to Moody's evaluation of the insurer's potential claims under economic stress."); Taub, Monoline Bond Reinsurers' Rising Entry Barriers, STANDARd \& Poor's CReditWeEk, Feb. 15, 1988, at 19, 20 (management would "offer key skills and experience in the insurance and reinsurance industries, credit analysis, and capital markets" and have to "demonstrate ability to establish strong operating and monitoring controls."). But see Elliott, Rating the Debt Raters, Instrtutional Investor, Dec. 1988, at 109, 112 ("[M]ost industrial companies feel that they receive perfunctory treatment when their debt is reviewed."); supra note 303 (concerning Washington Public Power System bonds).

314 For instance, in connection with the emergence of "defeasance-type" mortgage-backed bonds in 1988, Standard \& Poor's undertook a massive, multifaceted empirical analysis of such bonds' risk profile. See Raiti, The Defeasance Innovation, STANDARD \& POOR's CREDITWEeK, July 25, 1988, at 21; see also CMO Residuals, Standard \& Poor's CreditWeek, August 29, 1988, at 3 (describing the rating of collateralized mortgage obligation residuals as "among the most complex mortgage securities currently available"); Criteria Update: Two Years of Evolution, Standard \& Poor's CredrTWeek, Nov.24, 1986, at 1 (Nov. 24, 1986) (describing the methodology used for rating commercial mortgage-backed securities). 
designers of new securities, ${ }^{315}$ and the rating of financial guarantors is now so routine that published guidelines are available. ${ }^{316}$

The same rating agency which helps assure that the insurers understand new financial products would also serve to discipline the insurers from charging premiums which are too low. If the pricing is too low relative to the true risks of the swaps, not only will the insurer not earn a competitive rate of return, but it will also jeopardize its triple-A rating. ${ }^{317}$

Of greater concern are premiums which are too high. Overpricing could occur in two ways. First, if there are relatively few swap insurers, there is potential for collusion or other non-competitive pricing. This is of particular concern in the United States where the McCarran-Ferguson Act might severely limit the use of federal antitrust statutes to combat such overpricing. ${ }^{318}$ While anecdotal evidence suggesting that the pricing policies of financial guarantors have been on the low rather than on the high side is reassuring, ${ }^{319}$ the dangers of overpricing cannot be ignored. Second, the financial guaranty insurance industry in the United States has tended to be fairly conservative as to the bond issues it is willing to insure. ${ }^{320}$ If this manifests itself among swap insurers under the model scheme, the premiums charged may be too high.

I.

315 See Monroe, SEPP Are Thrust Into New Role, Wall St. J., Sept. 16, 1986, at 6, col.

316 See, e.g., Rating Methodology, Standard \& Poor's CreditWeek, Oct. 17, 1988 , at 6.

317 See, e.g., Greenwald, Rates Falling for Municipal Bond Cover, Bus. INs., Oct. 10, 1988, at 33, 36 (noting that price competition among municipal bond insurers limited by the need to keep triple-A ratings).

318 See 15 U.S.C. $\S \S 1012$ \& 1013(b) (1982) (limited federal antitrust immunity for the business of insurance); In re Insurance Antitrust Litigation, MDL No. 767 (N.D. Cal. Sept. 20, 1989) (LEXIS, Genfed library, Courts file) (lawsuit filed by 19 state attorneys general against numerous insurance companies dismissed on McCarran-Ferguson Act grounds); Note, Financial Guaranty Insurance: Is it "The Business of Insurance" Under the McCarran Act?, 1988 Colum. Bus. Rev. 855, 858 (discussing applicability of McCarran-Ferguson Act to financial guaranty insurance).

319 See Walters, Premium Battle Among Top Bond Insurers May Result in Coverage for Fewer Issues, BoND BuYER, Oct. 3, 1988, at 4 (available on NEXIS) ; Luxenberg, Buyer's Market for Insured Municipals, N.Y. Times, May 7, 1989, § 3, at 12, col. 3.

320 See, e.g., Milligan, supra note 275, at 197-98 (stating that a corporate bond insurer "strives for a no-loss underwriting result and will insure only obligations that already qualify as investment grade"); Singer, supra note $279, \S 2$, at 12, col. 3 (bond insurer stating that it furnishes bond insurance for "investment-grade offerings only, not for marginal credits"). But cf. Imperial Uses FSA to Set Overcollateralization Debt Deal, CoRP. FIN. WK., Mar. 7, 1988, at 2 (available on NEXIS) (describing a transaction in which the insured debt was collateralized with privately placed junk bonds). 


\section{Conclusions}

The arcane new financial products of this past decade have started to command attention. Apocalyptic visions of world-wide financial disaster caused by these products and images of panicstricken traders on the stock exchanges in New York and in the trading pits of Chicago reach mythical proportions and touch a primordial nerve. Bank regulators, with the BIS Accord, have seized the regulatory initiative. We are witnessing the creation of a new generation of financial regulation, a regime to deal with complicated products which now constitute pivotal elements of a globalized financial system. The BIS Accord is a supreme achievement, fashioning a regulatory structure based on remarkably sophisticated analyses and overcoming daunting international collective action problems.

However, the BIS Accord's reliance on legalistic solutions rigid, classification-based rules administered and maintained by government regulators - is reflective of a simpler, more static financial era. The process of financial innovation is now far too institutionalized and complex to be so confined. The science which started to drive finance this past decade has, in this paradigmatic case, outrun the art of financial regulation.

Financial regulators must develop a mechanism to deal explicitly with this underlying process. The difficulties involved in devising such a mechanism are daunting. A brief overview of one of the simplest, most incremental of possible mechanisms suggests the dimensions of the task. Unless we begin now to intensify our efforts, incremental changes may ultimately prove insufficient to ensure the continued stability of the world financial system. 
